\title{
Chapter? \\ Interaction of mangroves, coastal hydrodynamics and morphodynamics along the coastal fringes of the Guianas
}

\author{
Erik A. Toorman ${ }^{1 *}$, Edward Anthony ${ }^{2}$, Pieter G.E.F. Augustinus ${ }^{3}$, \\ Antoine Gardel ${ }^{4}$, Nicolas Gratiot ${ }^{5}$, Oudho Homenauth ${ }^{6}$, Nicolas Huybrechts ${ }^{7}$, \\ Jaak Monbaliu $^{1}$, Kene Moseley ${ }^{8}$, Sieuwnath Naipal ${ }^{9}$
}

\begin{abstract}
The mangrove belt along the coast of the three Guianas, South America, forms a unique ecosystem and acts efficiently as a natural soft coastal defence structure. The general mechanisms have been studied for over four decades and the processes governing the coastal morphodynamics are now understood, at least qualitatively. They consist of an interaction between mangroves, hydrodynamics and sediment mechanics. $20 \%$ of the mud discharged by the Amazon in the Atlantic Ocean is transported to the west along the coast by waves and currents in discrete mud banks of a few 10s of km length which travel at a speed of the order of $2 \mathrm{~km} /$ year. During the presence of a mud bank waves are damped, mud is trapped and colonized by mangroves. Once a mud bank has passed, the waves can attack the shore again. This results in a cycle of land accretion and erosion, with an average net gain of $1 \mathrm{~m}$ coast per cycle of roughly 30 years. However, in locations where too many mangroves have been removed, the coast has lost its natural resilience and the settlements and fields are prone to flooding, a concern that increases with climate change and predicted sea level rise (SLR). Hard coastal defence structures, such as those in Guyana, are expensive and not sustainable. Based on many lessons learnt, pilot projects on mangrove rehabilitation have started. At the same time research efforts are undertaken to allow making quantitative estimates of the potential risks for the coastal communities. For this purpose, numerical prediction models are developed which can compute currents, wave action and sediment transport along the coast of the Guianas. Different climate change scenarios can be investigated. These models can serve in the near future as decision support tool for the local authorities for the management of the coastal zone.
\end{abstract}

Keywords: Black mangroves, Amazon River mud, sea level rise, morphodynamic response, mangrove rehabilitation, Guianas coast.

\footnotetext{
${ }^{1}$ Hydraulics Division, Dept. of Civil Engineering, KU Leuven, Kasteelpark Arenberg 40 (box 2448), BE-3001 Leuven, Belgium - *Corresponding author: erik.toorman@kuleuven.be

${ }^{2}$ Université Aix-Marseille, CEREGE UMR CNRS 7330, Aix-en-Provence, France

${ }^{3}$ Prof. Emeritus, Faculty of Geosciences, Utrecht University, the Netherlands

${ }^{4}$ CNRS LEEISA USR 3456, Cayenne, Guyane Française

5 Centre Asiatique de Recherche sur l'Eau CARE, Bach Khoa University, VNU-HCM, Ho Chi Minh City, Vietnam; Université Grenoble Alpes, CNRS, IRD, Grenoble INP ${ }^{\circ}$, IGE, F-38000 Grenoble, France

${ }^{6}$ National Agricultural Research and Extension Institute (NAREI), Agriculture Road, Mon Repos, East Coast Demerara, Guyana

${ }^{7}$ CEREMA, Compiègne, France

${ }^{8}$ Mangrove Restoration and Management Department, NAREI, Mon Repos, East Coast Demerara, Guyana

${ }^{9}$ Land and Water Management, Dept. of Infrastructure, Anton de Kom University of Suriname (AdeKUS), Leysweg, Paramaribo, Suriname
} 


\section{?.1 Introduction}

Most mangroves are found in coastal lagoons and in estuaries, sheltered from waves. There are very few places around the world where they form a protecting belt along the coast itself, where they are subject to direct wave action.

\section{?.1.1 The Guianas coast}

Probably the most remarkable mangrove coastal fringe is found along the Guianas coast, stretching from the mouth of the Amazon River in northern Brazil all the way west to the mouth of the Orinoco river in Venezuela, a stretch of roughly $1600 \mathrm{~km}$ (Figure 1). Unfortunately, the mangrove belt has been reduced or removed in many places, making place for other land use (mainly agriculture, aquaculture and urban expansion), creating many vulnerable spots where hard coastal protection structures had to be built to protect the hinterland against flooding.

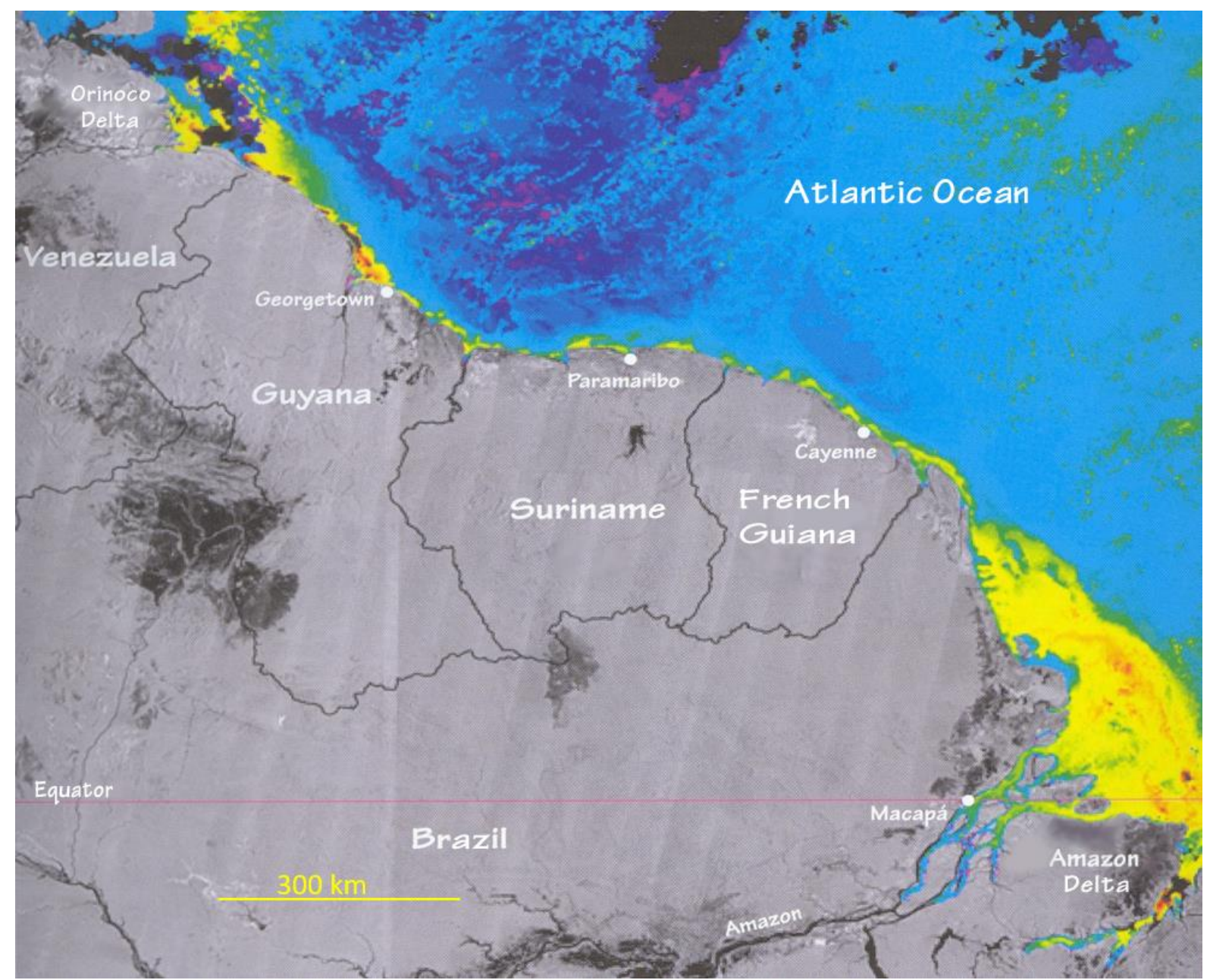

Figure 1 Situation of the study area. Satellite image (processed), showing the turbidity along the north-eastern coastline of South-America (NOAA images, October 1999; Laboratoire Regional de Télédétection, CNRS - after Gratiot 2011)

The investment and subsequent maintenance costs of these dikes are extremely high. This is especially problematic for Guyana, where mangroves have been replaced by a sea defence 
wall along about $40 \%$ of the coastline in order to protect the polders which are used for agriculture. Pelling (1999) presents an analysis of the vulnerability of the Guyana coast from the perspective of political ecology, starting with a historical review which traces its roots. The estimated yearly maintenance cost for Guyana is very high. A cost/benefit analysis by Odle and Arjoon (1971) indicates that too little has been invested in the maintenance of the sea wall. The Guyana Ministry of Finance (1996) estimated the approximate annual cost to maintain and rehabilitate sea defence works over the short term to about 7.5 million USD annually, 5 million USD over the medium term and 2.5 million USD over the long term. Eventually, under the 10th European Development Fund framework from 2007 to 2013, the EU-Guyana cooperation focussed a.o. on sea defences. This resulted in a Coastal Engineering Design Manual for the Guyana Sea an River Defences, compiled by four consultants, which was handed over in July 2016 by the EU, together with funding of 10 million USD to get the necessary actions started (Guyana Government Information Agency 2016).

Moreover, hard sea defence walls too close to the high-water line, as build in Guyana, prove to increase the problem of mangrove establishment, because the reflection of waves on the hard structure enhances the resuspension of sediments (Anthony and Gratiot 2012). By fluidizing the mud flat, the waves weaken the erosion resistance. Fluidized mud on the bottom may start to flow down the intertidal flat to deeper water offshore. By generating more turbulence, cohesive sediment flocs break up into even finer particles that more easily wash away.

The damage is much less in Suriname and French Guiana (Guyane Française). In Suriname, only a few kilometres of dike are constructed in Nickerie and recently in Coronie. By building the Coronie dike a bit further from the high-water line, behind a remnant of mangroves, waves will not directly impact with the hard structure and reflection of waves on the wall is reduced. In the meantime, the construction has been temporized because during the operations a new mud bank arrived, which has rapidly been colonized by mangroves. This decreased the necessity and changed the priorities.

In French Guiana only dozens meters of riprap have been constructed in urban places in Cayenne and Montjoly. In the Anse district of Kourou city a $900 \mathrm{~m}$ long sandy dune has been erected in 2016 to protect houses from erosion and submersion. Local authorities opted for this temporary solution awaiting to find a more long-lasting soft solution.

Over the past years, a growing awareness has risen among policy makers and the population that integrated coastal zone management requires a more sustainable coastal defence strategy, certainly in the light of climate change and associated sea level rise (SLR) in particular. Thanks to increasing understanding over the past years of the natural processes controlling the interaction between morphodynamics and vegetation and their potential to create natural barriers to stabilize beaches and shores, the concept of soft shore protection has become an interesting design strategy for shore management. This chapter gives an overview of how this concept is currently under investigation for the Guianas mangrove coast.

\section{?.1.2 Mangroves along the Guianas coast}

\section{?.1.1.1 Species}

Mangroves are trees with unique adaptations which allow them to survive on anaerobic, soft muddy soils in relatively high saline environments. This explains why they are found in coastal areas, where they are not competed away by other species. 
Unlike other coasts, the Atlantic coast of the Americas knows only a few species of mangroves. The coastal fringe in the Guyanas is dominated by the black mangrove (Avicennia germinans) with prop roots (Figure 2). Red mangroves (predominantly Rhizophora mangle), with stilt roots, occur along the borders of tidal rivers and creeks. They are rarely found along the coast itself (Figure 3).

White mangroves (Laguncularia racemosa) are less common; they occur on somewhat higher, more sandy soils, e.g. creek levees. They also have prop roots.

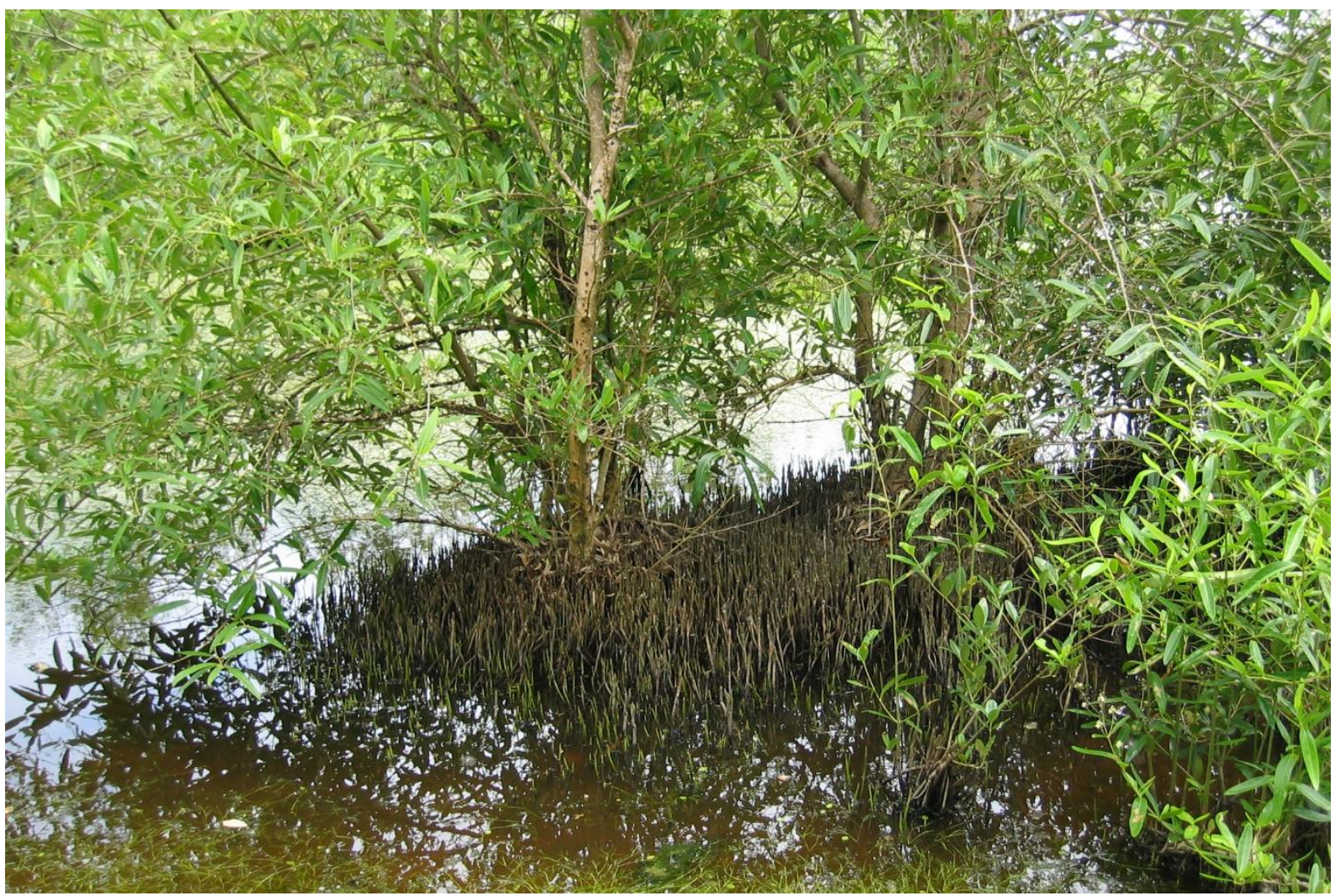

Figure 2 Black mangrove (Avicennia germinans), with its well-developed pneumatophores (prop roots). (Credit: P. Augustinus)

\section{?.1.1.2 Mangrove degradation}

Mangroves have adapted to grow in saline environments. Under hypersaline conditions however, even Avicennia germinans cannot survive. In the Guianas, these conditions may develop under natural circumstances, e.g. when a mangrove forest is closed from the sea by a new forming chenier (Figure 4), impeding the natural in- and outflow of water. Especially in the dry season, the salinity of the stagnant water can rise quickly, due to evaporation, causing the sudden death of the mangroves. During the next wet season, the salinity will be lowered, and through a transition phase with saline herbs, the mangrove vegetation can restore itself again in the course of time (Figure 5).

Sometimes however, the degradation of mangroves is due to human impact, such as in Coronie (Suriname), where the freshwater inflow from the coastal swamps is cut off by the main coastal road. The sea water evaporates and leaves behind extreme high-saline pools, in which the mangroves cannot survive (Figure 6). In these cases, the degradation usually has a more permanent character. 


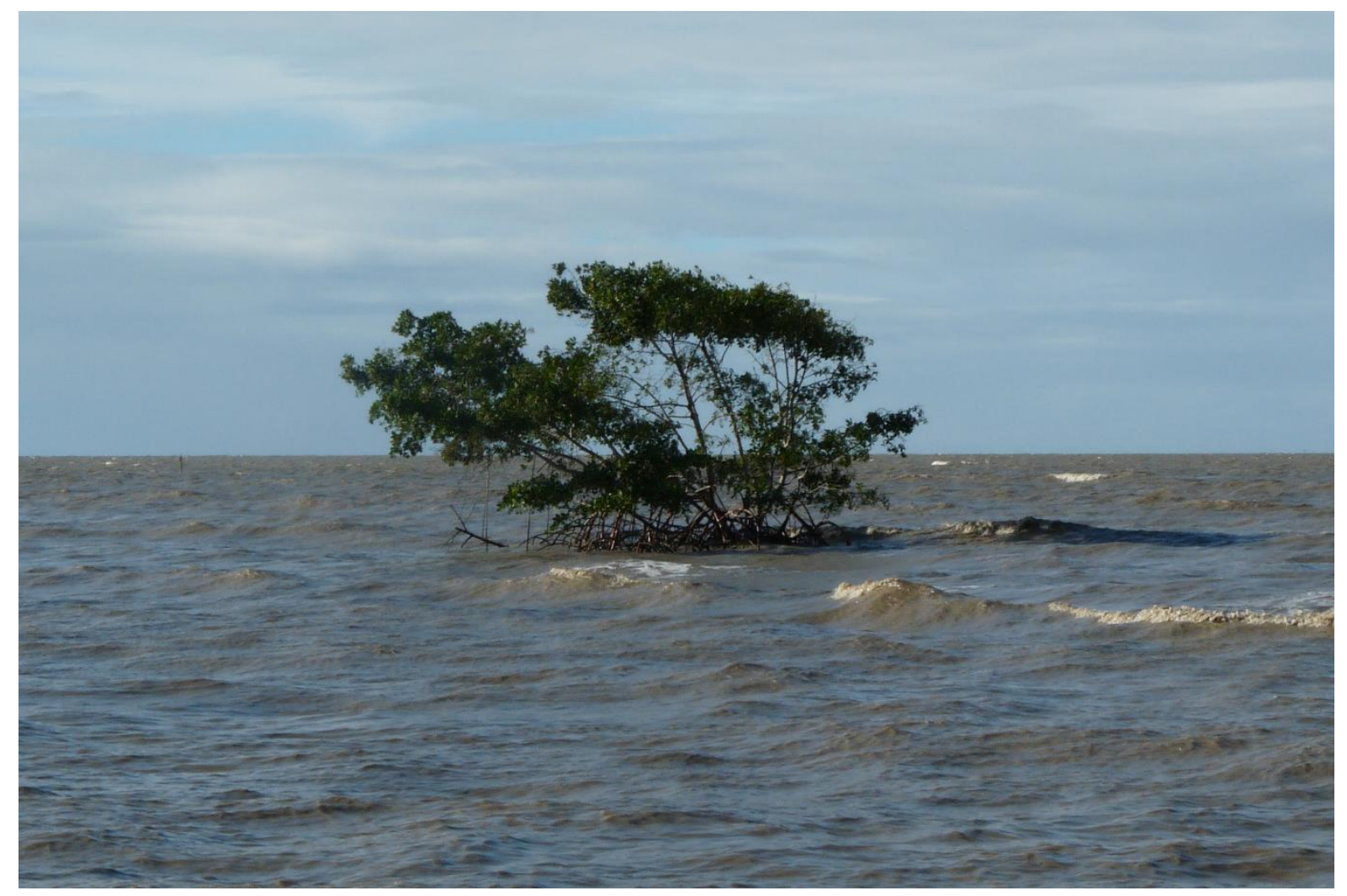

Figure 3 A remarkable sight: a lonely, persisting Red mangrove (Rhizophora mangle) that refuses to be washed away along the eroded coast in front of Weg naar Zee (Suriname, 2011). (Credit: E. Toorman)

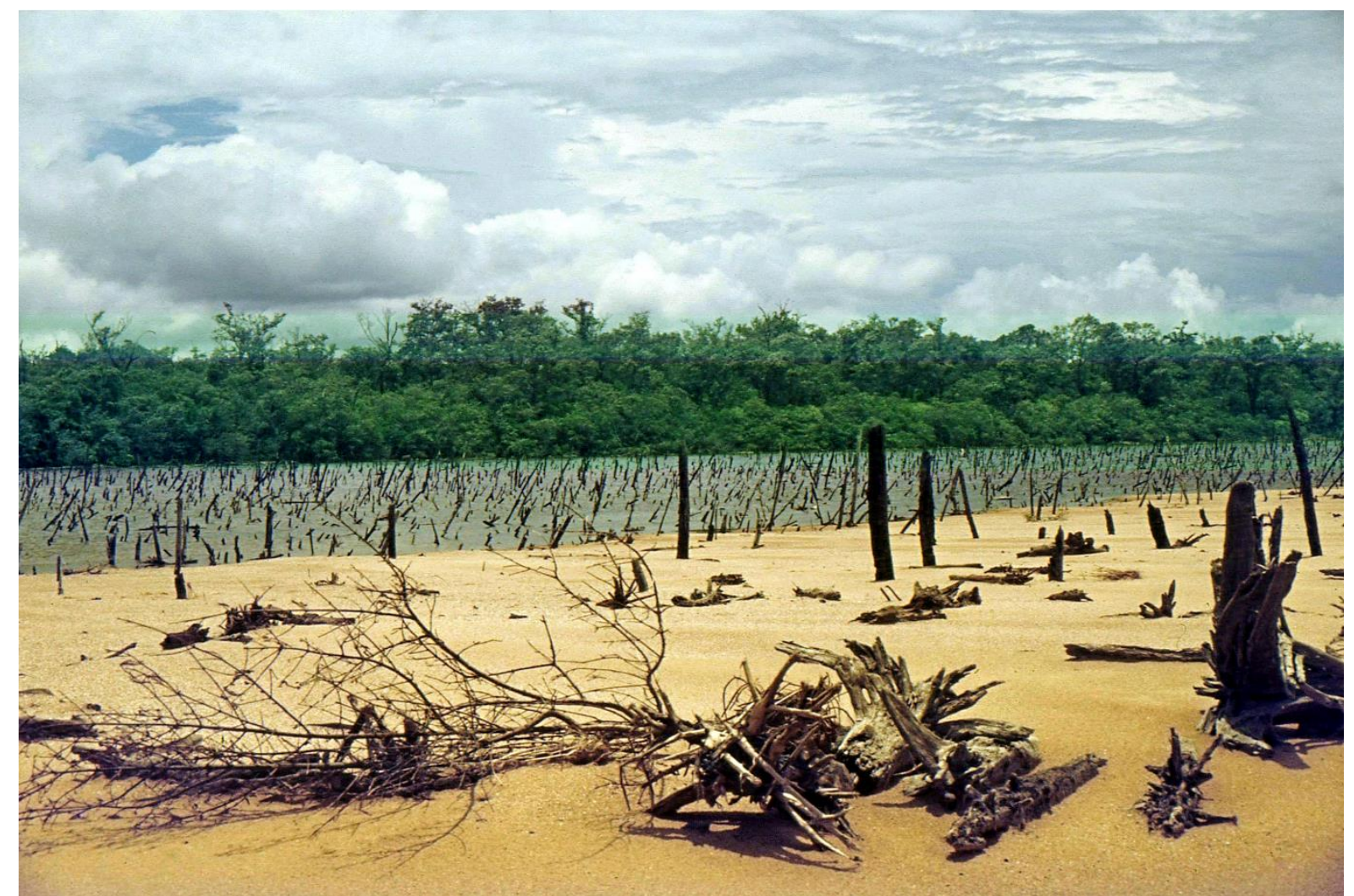

Figure 4 Dead mangroves (Avicennia germinans) in a hypersaline environment behind an actual chenier in East Suriname (Credit: P. Augustinus). 


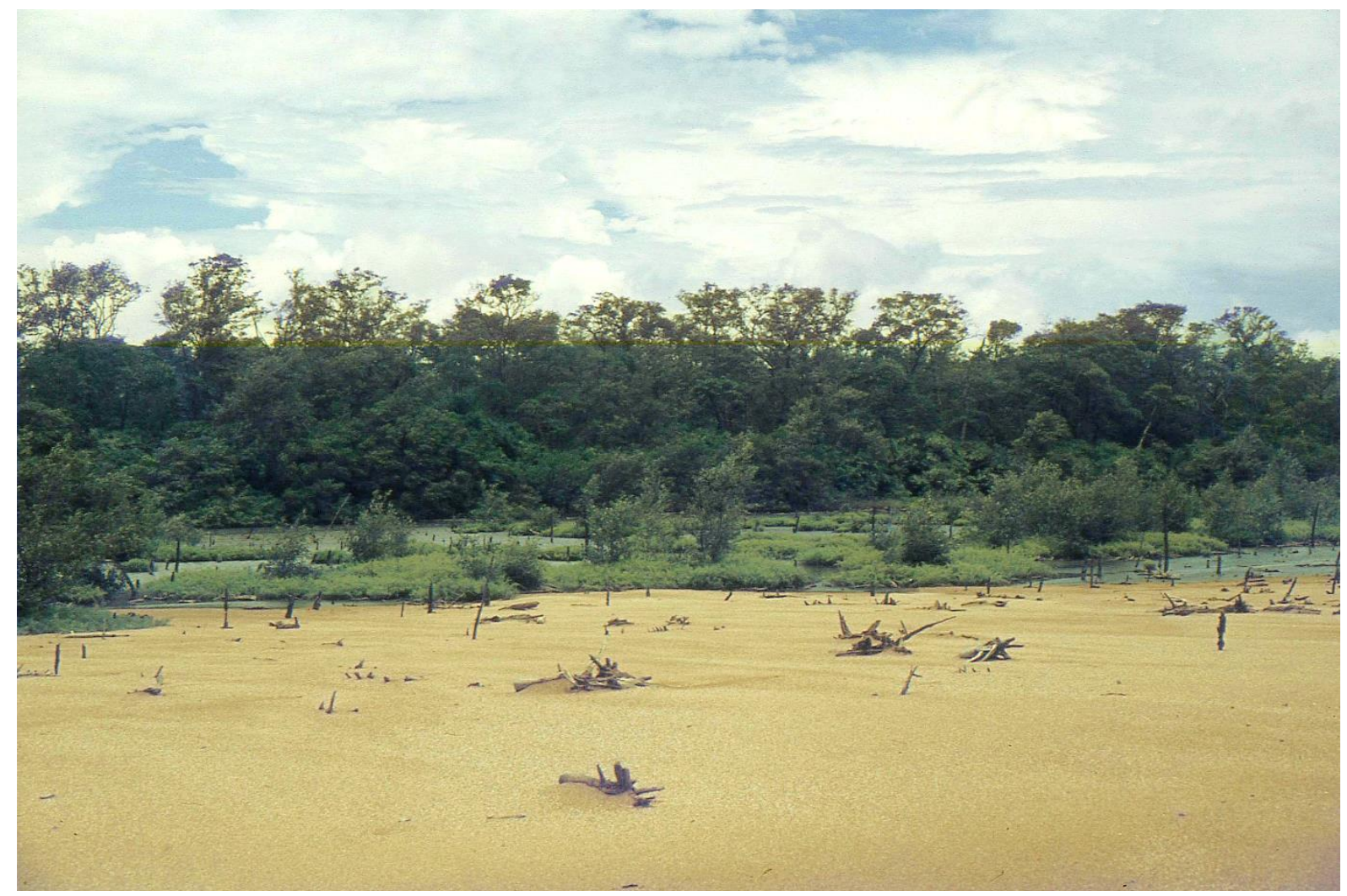

Figure 5 Recovering saltmarsh vegetation in a former hypersaline environment behind an actual chenier in East Suriname (Credit: P. Augustinus).

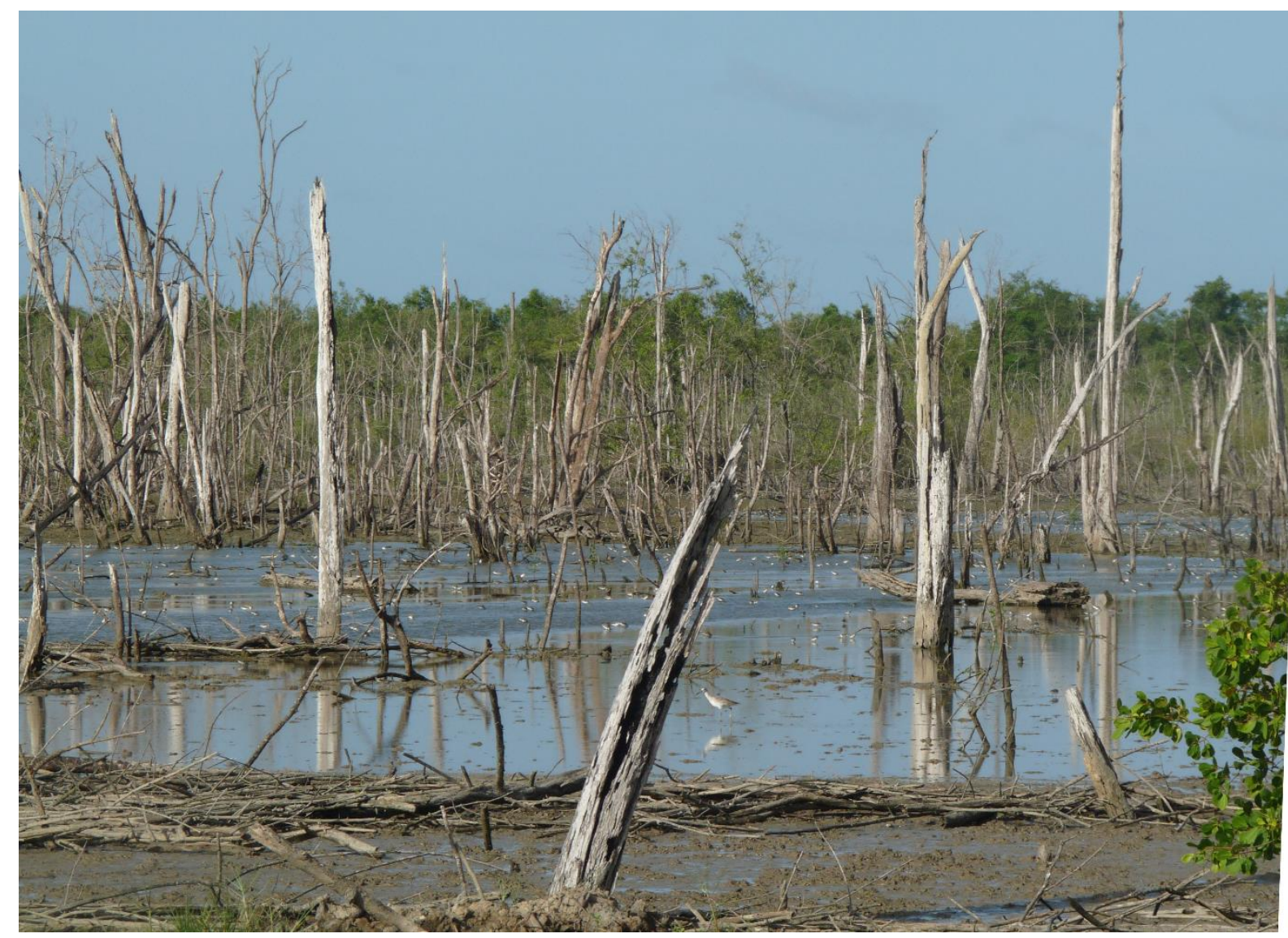

Figure 6 Dead trees in hypersaline water in Coronie (Suriname, 2010), cut off from the inland fresh-water marshes by the main east-west road. (Credit: E. Toorman) 


\section{?.2 Morphodynamics of the Guianas Coast}

\section{?.2.1 Mud bank migration}

The Guianas coast has been studied for a long time, with the work by Augustinus (1978) as the main pioneering physical research. These studies have revealed the major processes that explain the formation of the Holocene coastal plain over the past 6000 years, which has gradually accreted at a mean rate of the order of 2 meter per century (Rine 1980). This can be summarized as follows (Allison 2000, and Augustinus 2004).

About $20 \%$ of the continuous flux of sediments by the Amazon river into the Atlantic Ocean is transported westward along the North coast of South America. Some $150 \times 10^{6}$ tons is transported yearly as suspension load, another $100 \times 10^{6}$ tons per year in the form of huge mud banks, which travel at an average speed of roughly $2 \mathrm{~km} /$ year in westerly direction. Waves are the driving force behind this migration (Nedeco 1972, Allison and Lee 2004). The question why an important part of the mud transport takes place in discrete banks of roughly $30 \mathrm{~km}$ length is still not well understood.

In the classic model, mud banks are shore face attached (e.g. Delft Hydraulics Laboratory 1962, Allersma 1971, Augustinus 1978, Wells and Coleman 1981; Rine and Ginsburg 1985). This is shown in Figure 7A. The migration of the mud banks is caused by erosion of their trailing edge (East side) and the deposition, mainly of fluid mud, at their leading edge (West side).
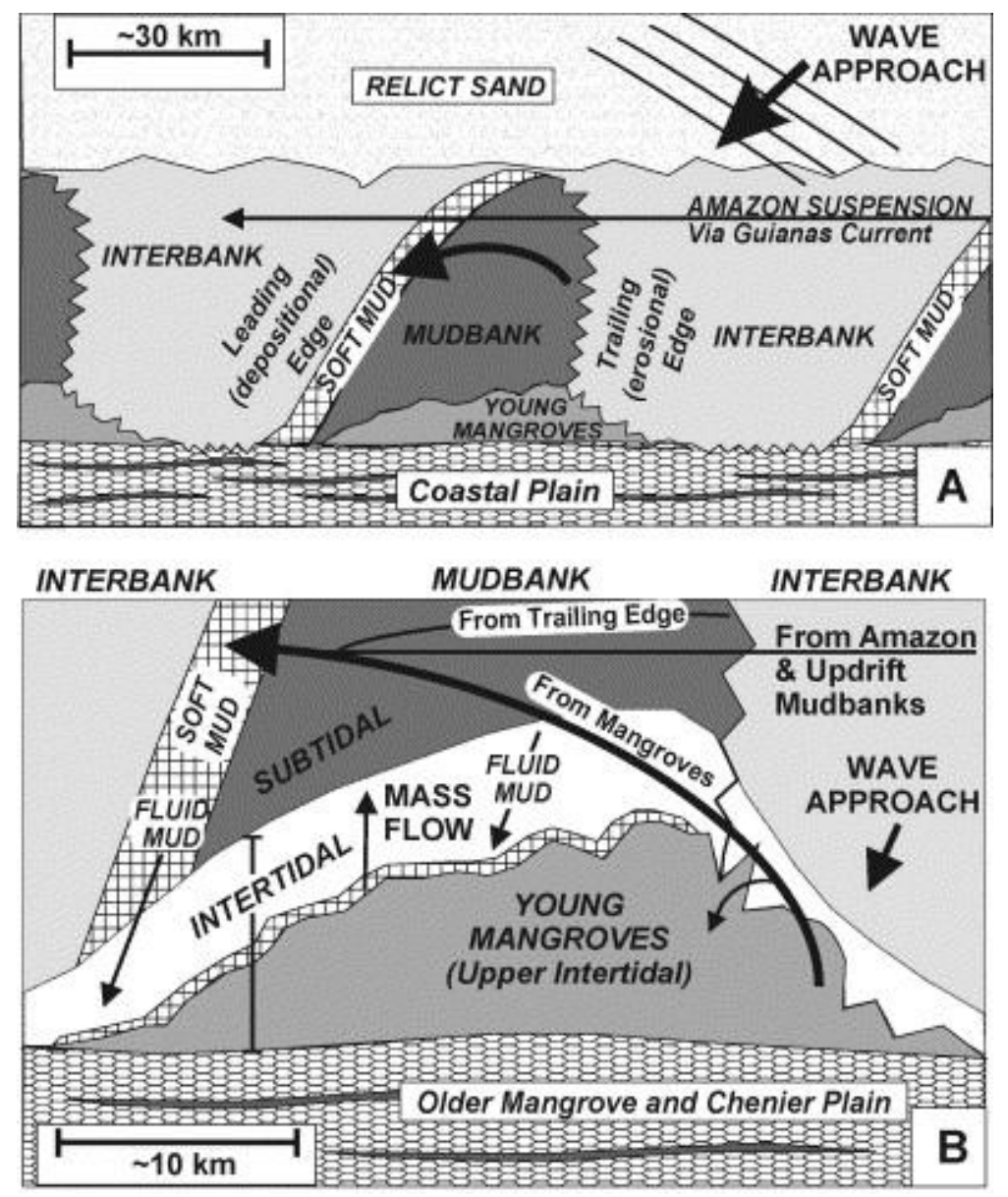

Figure 7 The classic model for mud bank migration (A) and mud bank dynamics (B). (Allison and Lee 2004) 
Figure 7B shows the mud bank dynamics according to Allison and Lee (2004). In their hypothesis the mud bank is disconnected from the coast. During flood, fluid muds are driven shoreward over the mud bank, filling the upper intertidal area between the mud bank and the coast. The fluid mud originates from the transported suspension load as well as from erosion of the trailing edge of the mud bank. If the concentration of silt particles in the water exceeds the point of hindered settling, fluid mud is formed. It is so soft, that it absorbs the energy of surpassing waves by visco-plastic deformation (i.e. friction between the sediment particles). This means that waves running into an area with fluid mud are strongly attenuated and even may disappear (Figure 8). As a result, deposition is further enhanced.

In the course of time, the mud consolidates and becomes more compact. A hydrographic pattern develops and mangroves start to grow (Figure 9). Mangrove roots give rigidity to the soil and further its compaction by extracting water (Figure 10).

Moreover, the complex system of above-ground prop roots, branches and stems act as an increased surface roughness for incoming waves and currents, which therefore lose energy. So vital mangroves capture sediments, resulting in coastal accretion in the quiet zone between the mud bank and the shore. New mangrove propagules will colonize the new land, stabilize its soil enhancing further accretion. However, with ongoing consolidation (i.e. self-weight compaction; Toorman 1996) towards the east, the mud matures into a young clay, which can be eroded.

Therefore, when the mud bank has passed (after roughly 30 years), the waves will break without significant attenuation on the shore, washing away sediments between the mangrove roots and eventually uprooting the trees: the shore will erode. The uprooted trees may pile up against the living trees, forming extensive accumulations of stems and branches (Figure 11). These act as an increased bottom roughness, slowing down erosion.

When, after some 30 years, in which a mud bank and the adjacent interbank area has been completely migrated westward, a new mud bank settles in front of the mangrove forest under erosion, a new cycle begins.

If the width of the vital mangrove forest has been sufficient large, the coast may have accreted. However, the opposite is also possible. In the period 1947-1966 the coast of Suriname shows net erosion over its full length. From 1966 onwards, net coastal accretion takes place (Table 1). This net accretion can (at least partially) be explained by the observed increase of the sediment discharge of the Amazon river. A recent study by Martinez et al. (2009), based on the analysis of an extensive time series of field data (10-day sampling) and satellite data show an increase of the yearly-averaged sediment discharge from 1995 to 2007 by $20 \%$, which is not correlated to the nearly unchanged annual river discharge. The increase may be attributed to stronger erosion caused either by climate change (intensification of rainfall) or by land cover changes resulting from deforestation (Callede et al., 2008). Since another study (Filizola and Guyot, 2009) indicates that $90 \%$ of the sediment load originates from the Andes, the deforestation of the lowland rainforest of the Brazilian shield most likely is not the main contributor. 


\begin{tabular}{|c|c|c|}
\hline \multicolumn{2}{|c|}{ Period } & \multirow[b]{2}{*}{$\begin{array}{c}\text { Net amount of sediment } \\
\times 10^{6} \text { tons/year }\end{array}$} \\
\hline Interval & $\begin{array}{c}\text { Number of } \\
\text { years }\end{array}$ & \\
\hline $2001-2007$ & 6 & +59.44 \\
\hline $1992-2001$ & 9 & +29.07 \\
\hline $1981-1992$ & 11 & +48.43 \\
\hline $1970-1981$ & 11 & +7.61 \\
\hline $1966-1970$ & 4 & +2.18 \\
\hline $1957-1966$ & 9 & -1.00 \\
\hline $1947-1957$ & 10 & -0.82 \\
\hline \multicolumn{3}{|c|}{$\begin{array}{l}\text { Remarks: The coastline in } 1992 \text { has been drawn using aerial } \\
\text { photographs. For } 2001 \text {, satellite images with a lower resolution are } \\
\text { used. The amount of sediment in the intermediate period is } \\
\text { therefore less accurate (probably too high), compared to the other } \\
\text { intervals. }\end{array}$} \\
\hline
\end{tabular}

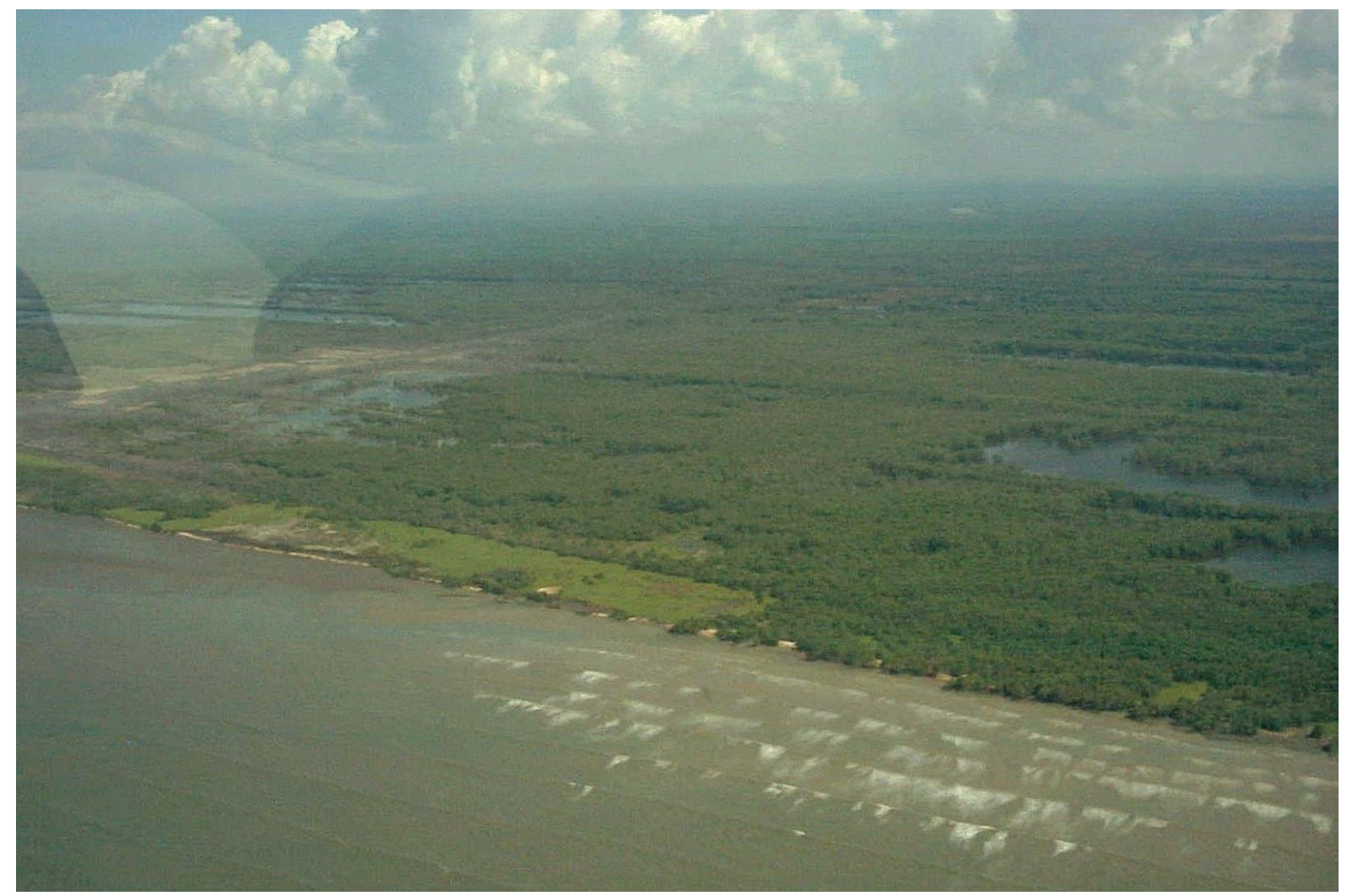

Figure 8 To the left one notices the sudden disappearance of waves running over fluid mud. (Credit: P. Augustinus) 


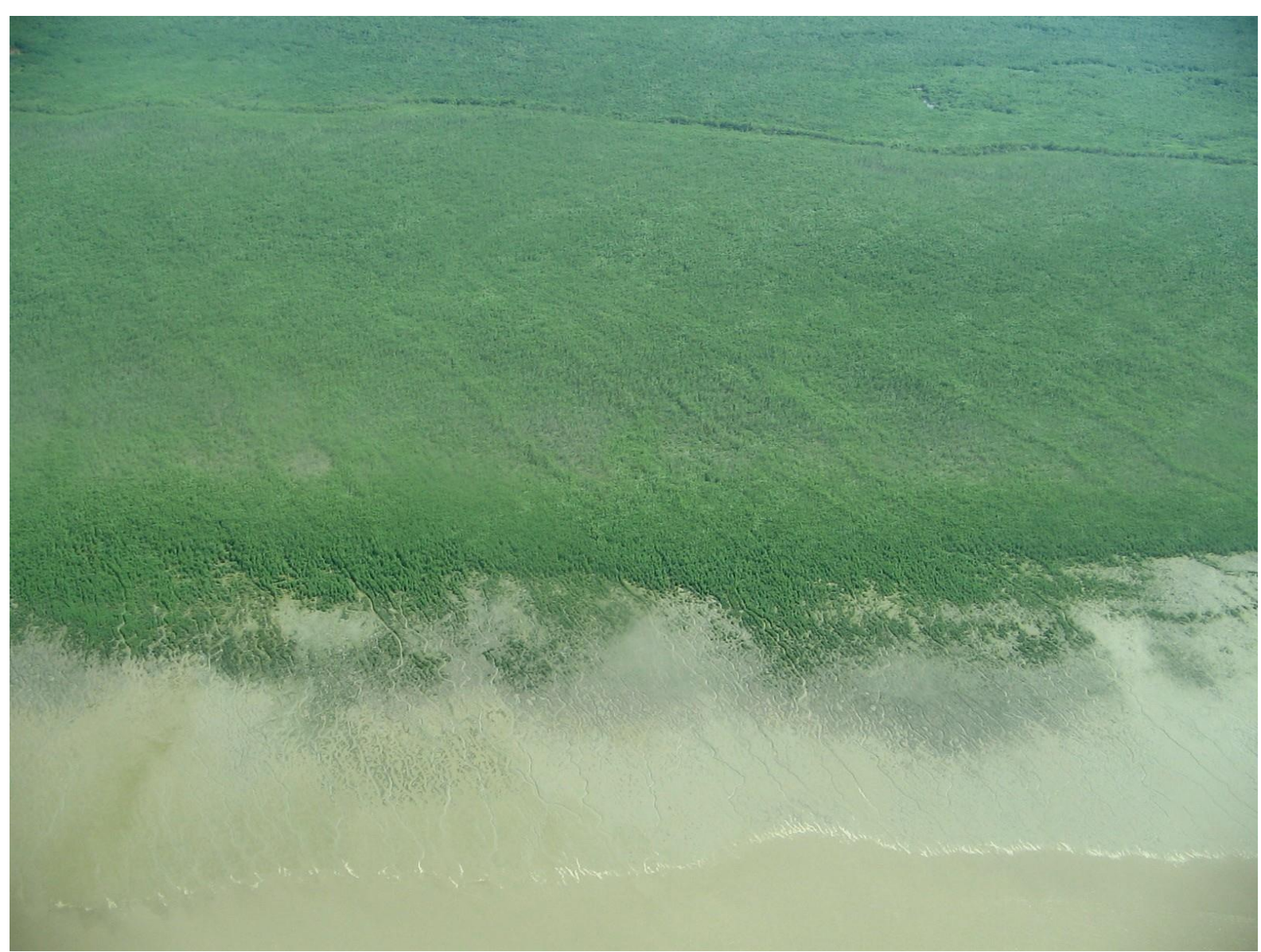

Figure 9 A vital mangrove vegetation growing on relatively young clay. (Credit: P. Augustinus)

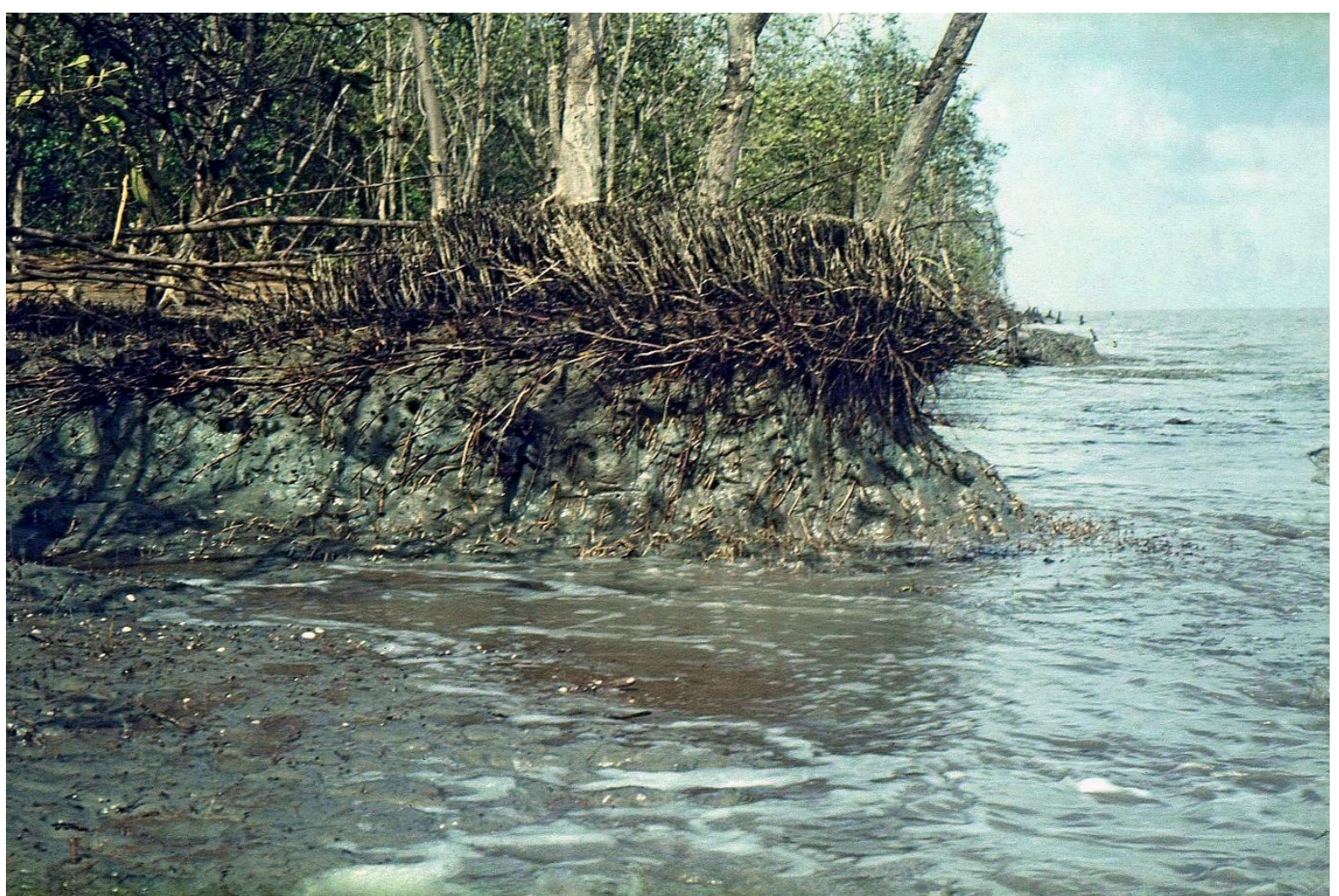

Figure 10 Eroded coast with protruding mud, protected by roots of Avicennia germinans. (Credit: P. Augustinus) 


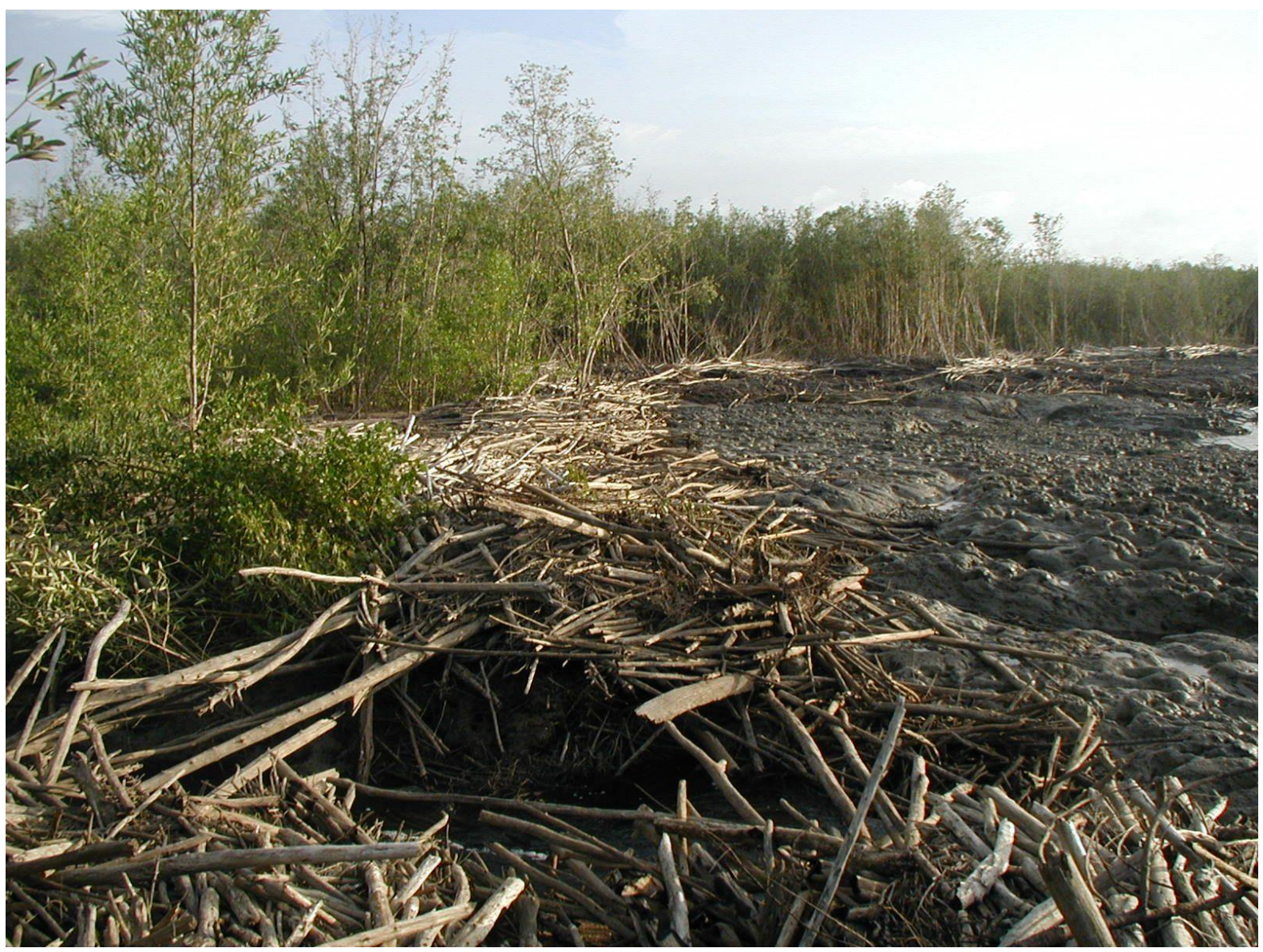

Figure 11 Accumulation of uprooted mangrove trees against the living trees in Coronie (Suriname, 2004). (Credit: P. Augustinus).

This large scale coastal behaviour is probably caused by a (cyclic) shifting of wind frequencies. In the sixties and seventies of the former century, winds from an east-north-eastern direction steadily increase and so does the wind strength. Waves generated by winds from that direction approach the shore under a smaller angle. Therefore, the component of the wave energy flux parallel to the coast $\left(\mathrm{P}_{2} \mathrm{a}\right)$ becomes more important, compared to the component of the wave energy flux perpendicular to the coast $\left(\mathrm{P}_{2} \mathrm{O}\right)$ (Figure 12). So sediment transport is furthered and erosion is diminished. This must lead to a growth in length of the mud banks, which is indeed the case (Figure 13).

Since 2001 the average length of the mud banks is slightly decreasing. This could indicate the beginning of an increase in the frequency of more northern (or north-north-eastern) wind directions. In addition, the El Nino and the La Nina events also have impact on wind and rainfall. Sometimes even hurricane influences are noticed, even though the Guianas coast lies outside the hurricane area. To our knowledge, these possible effects on the mud bank migration have not yet been studied. 


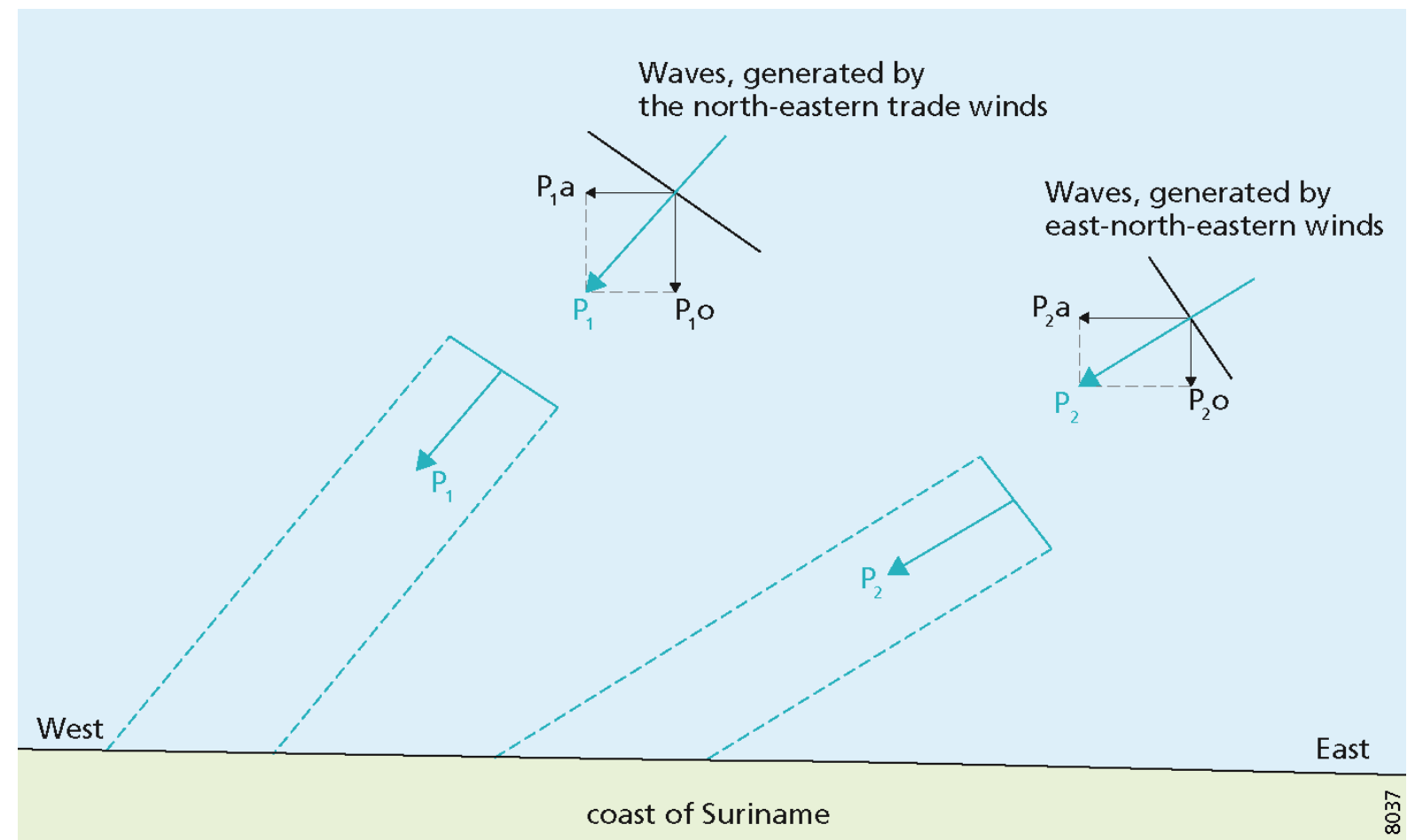

Figure 12 The influence of the difference in the angle of approach of waves, generated by the north-eastern trade winds $\left(\mathbf{P}_{1}\right)$ and waves generated by east-north-eastern winds $\left(\mathbf{P}_{2}\right)$. Energy flux $\mathbf{P}$ is defined as the transport of energy through a vertical plane, parallel to the wave crests, per unit crest length. Po is the landward directed component of the wave energy flux, Pa is the component parallel to the coast. (after Wong et al 2017)

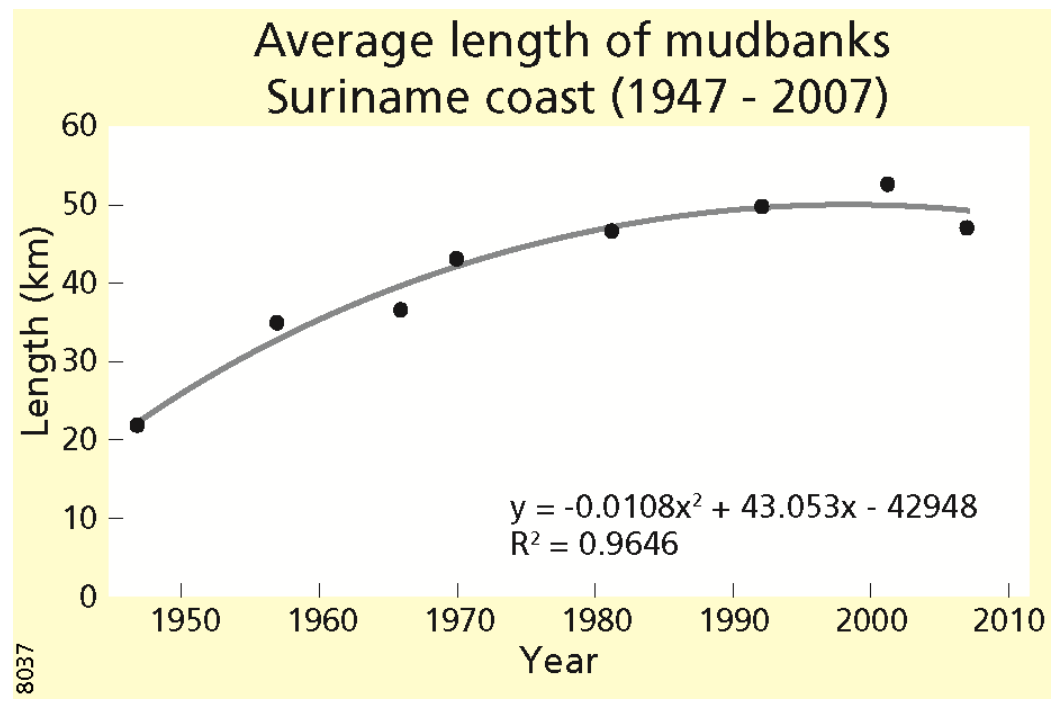

Figure 13 Average length of the mud banks in Suriname, deduced from aerial photographs and satellite images. (after Wong et al 2017)

\section{?.2.2 Coastal erosion analysis}

Erosion of the muddy coast of the Guianas begins with the development of small pits in the bare mud surface in front of the mangrove vegetation. The slightly consolidated mud in front of the Avicennia germinans vegetation has a brownish colour due to the presence of diatoms. 
The small erosion pits are filled in afterwards with lighter coloured fresh mud, which makes them easily recognizable (Figure 14).

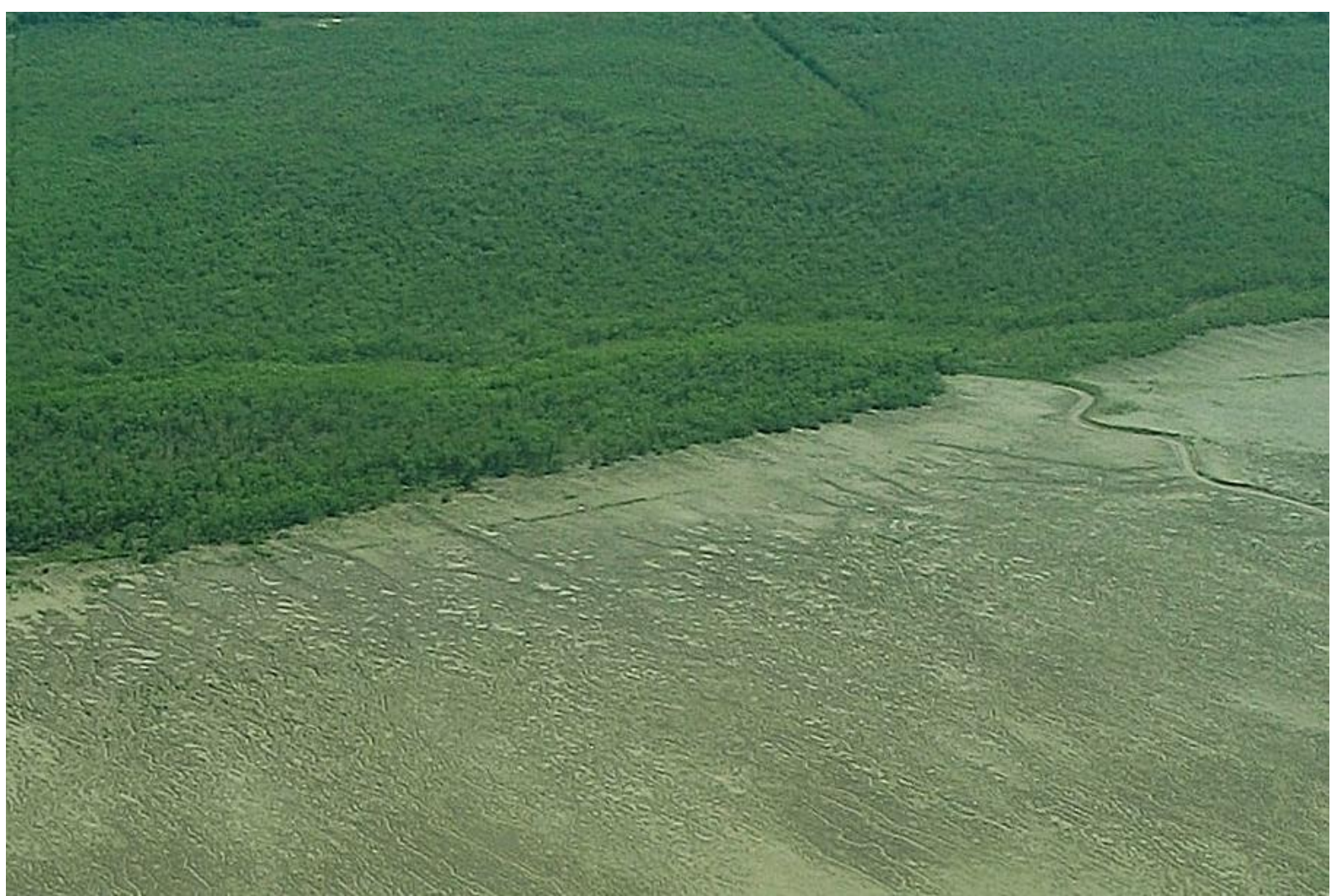

Figure 14 Erosion pits in the mud surface in front of vital black mangroves (Avicennia germinans) in Suriname (2006). They are filled in afterwards by lighter coloured fresh mud, which contrasts with the brownish colour of the mud surface, due to the presence of diatoms. (Credit: P. Augustinus)

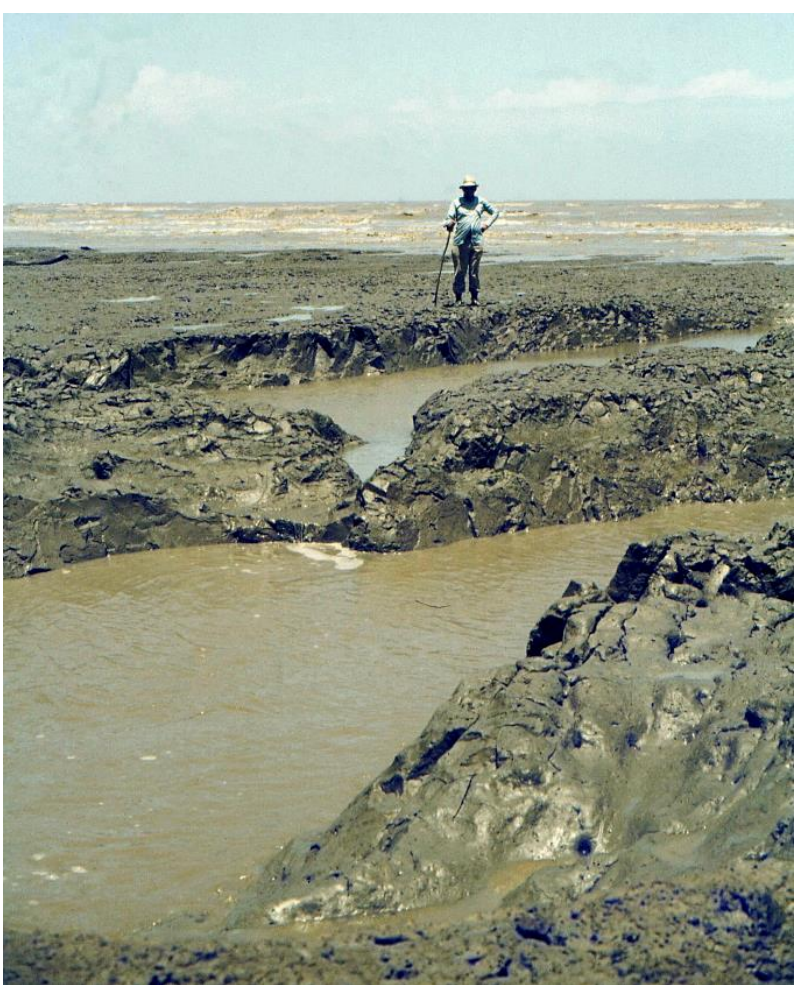

Figure 15 Coastal erosion in Coronie (Suriname, 1972). (Credit: P. Augustinus)
With increasing degree of consolidation, the erosion depressions become larger and more elongated. They develop in the direction of wave attack (Figure 15). During ebbtide, when exposed to the sun, the walls desiccate, the clay shrinks and cracks appear parallel to the walls. With the next rising tide, rotational sliding along the sheer faces occur, resulting in a widening of the depressions. In areas where many of these depressions are concentrated the original clay surface is more lowered than elsewhere. In this way, an indented erosion coasts develops (Figure 16). 


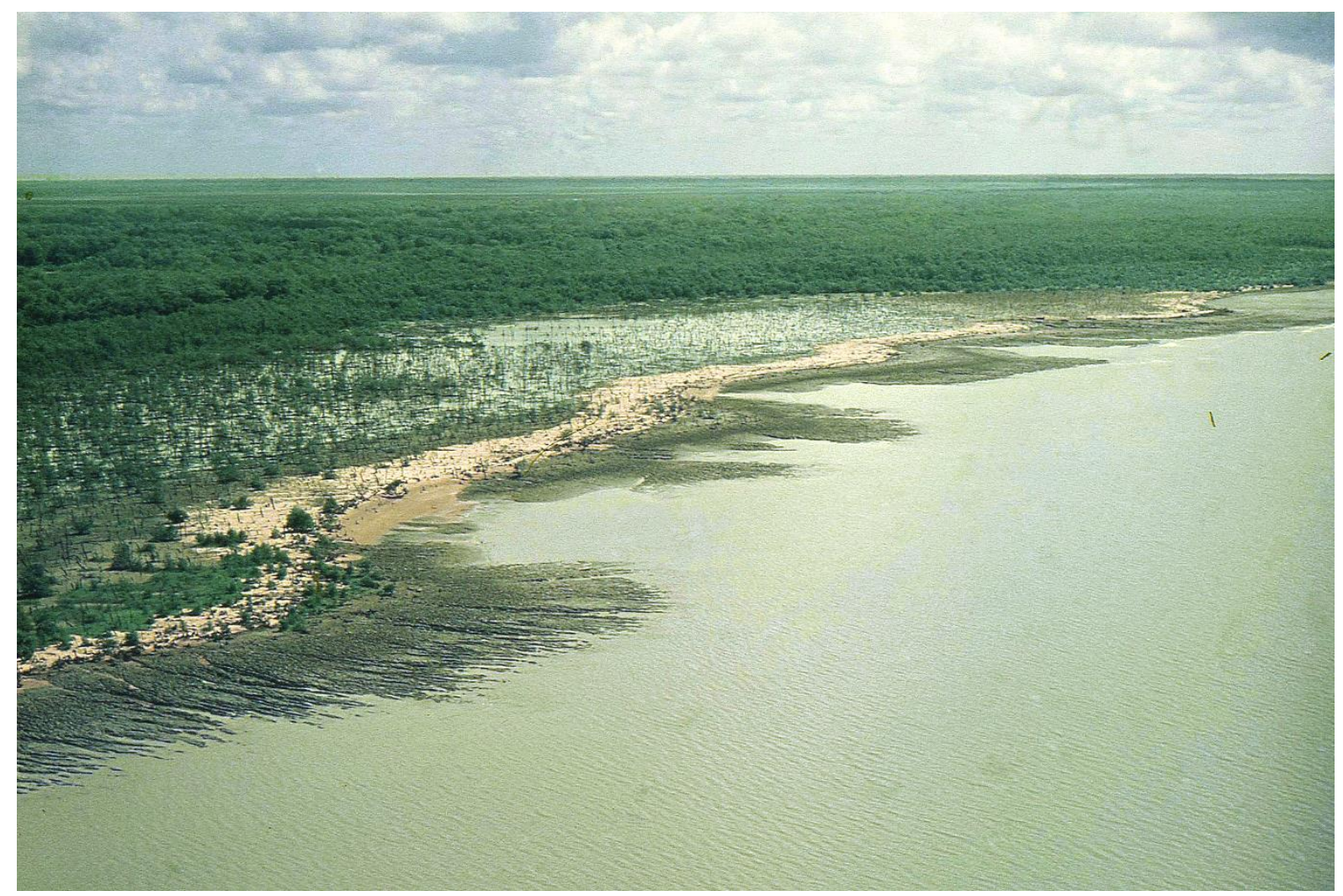

Figure 16 Indented erosion coast in East Suriname (1972). (Credit: J. Schulz)

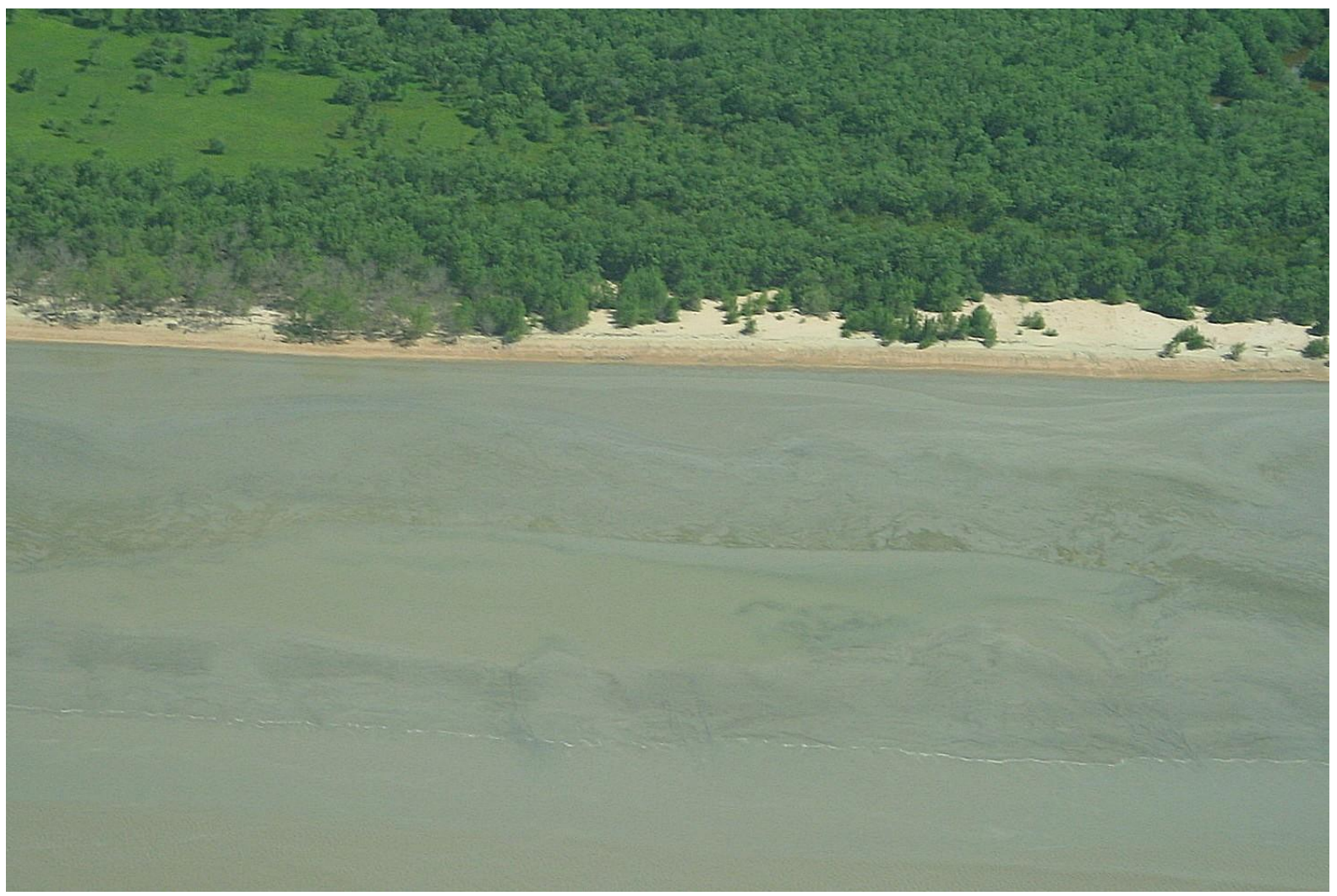

Figure 17 A landward migrating chenier along the coast of Commewijne (Suriname, 2006). (Credit: P. Augustinus) 


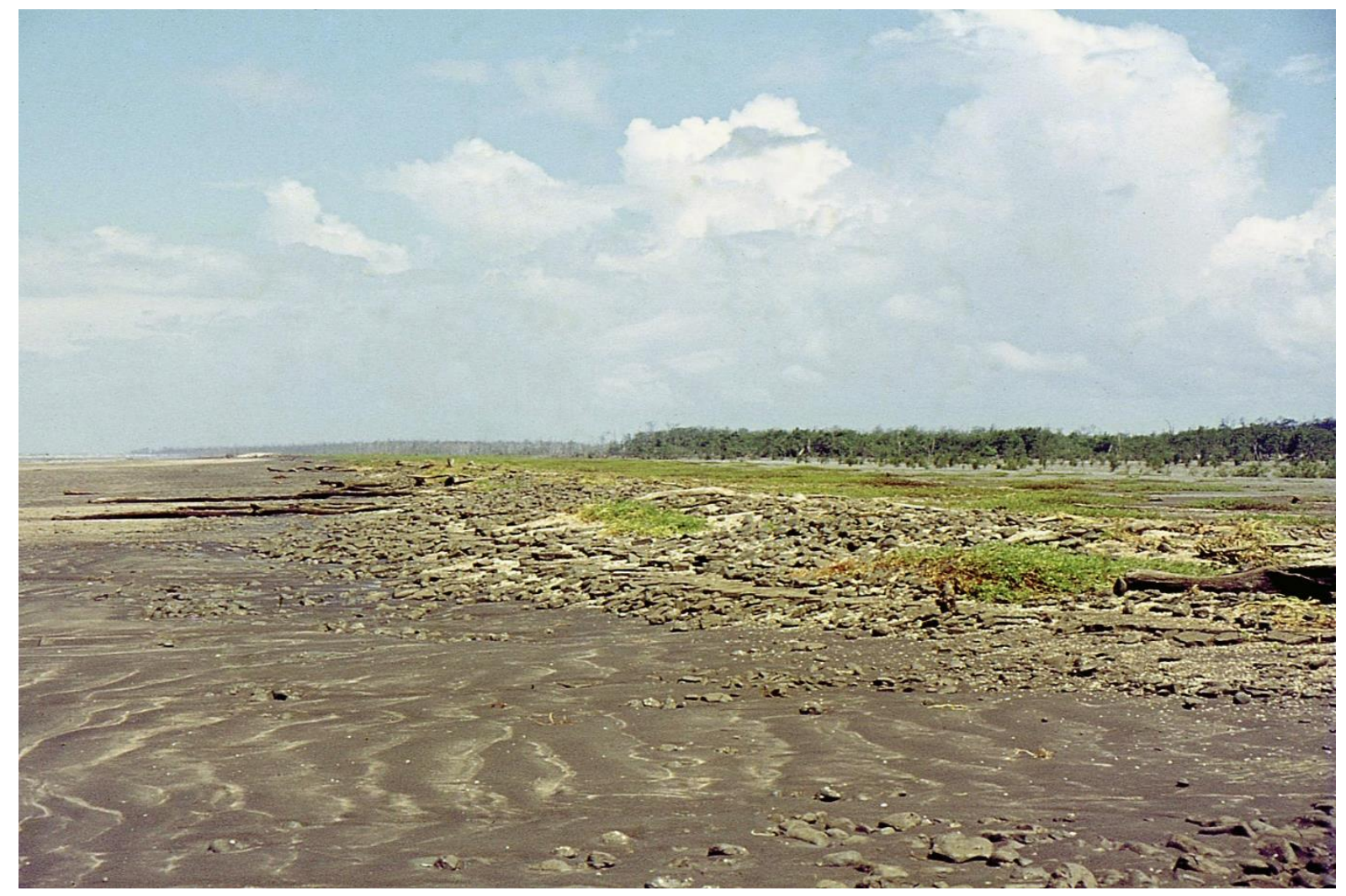

Figure 18 Fine sandy chenier in Coronie, Suriname (1972). The development of this type of chenier starts at low water level. Note the ripples on the foreshore. (Credit: P. Augustinus)

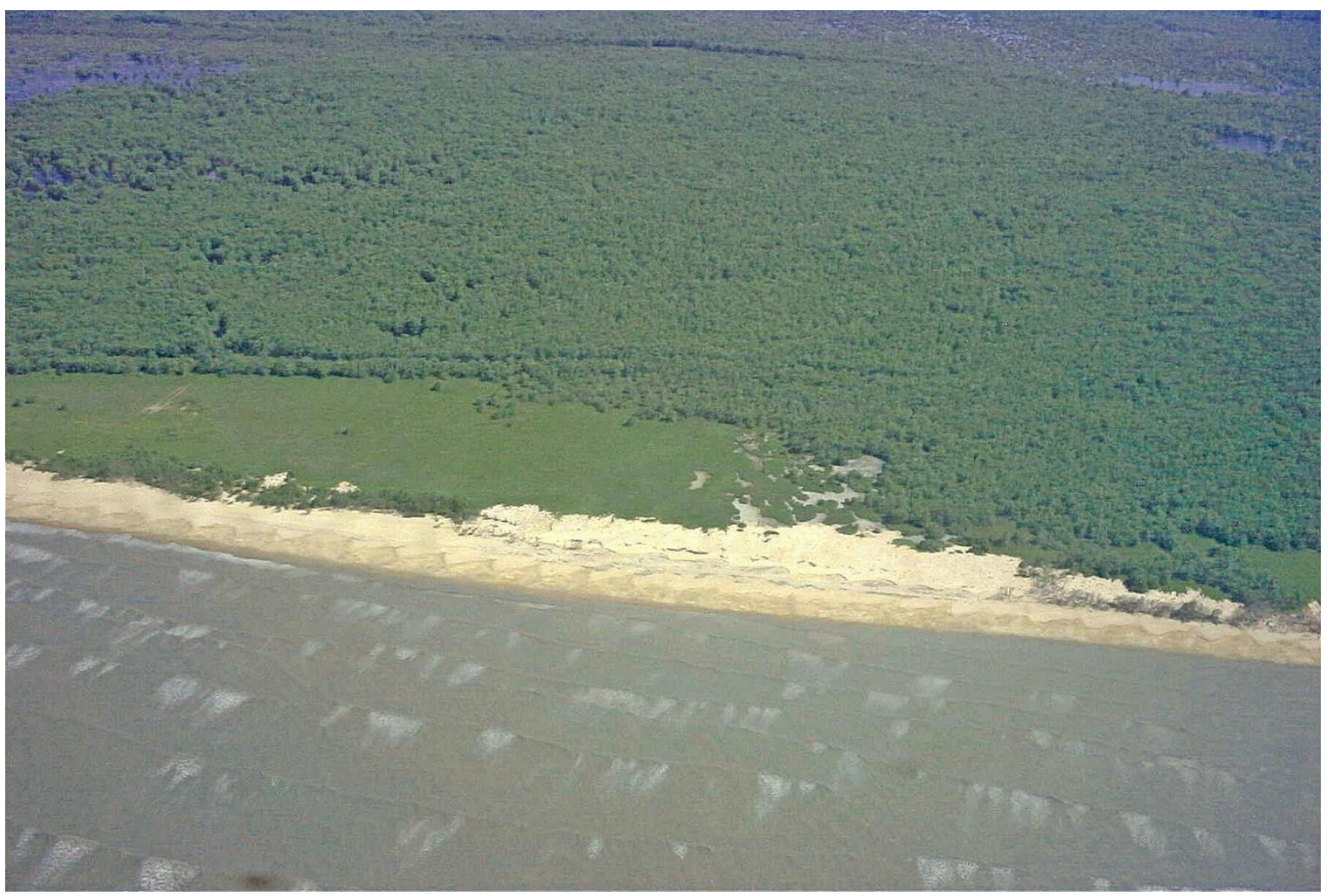

Figure 19 Seaward extending beach near Diane Creek, Commewijne, Suriname, with rows of beach cusps. (Credit: P. Augustinus) 
Erosion is dominant in the interbank area. The incoming waves erode the clay surface and cheniers are formed. If sand is available from a local source, e.g. the Marowijne River or the Corentyne River, it is transported in the coastal zone by longshore drift and beach drift. The cheniers develop at or just above mean high tide level. During higher water levels, sand is washed over the top of the chenier to its backside. This causes the chenier to migrate landward (Figure 17). In the mean time they may grow in height and therefore progressively counteract coastal erosion.

If there is no sand available from local sources, sand can be winnowed from the mud. The muddy sediment contains approximately $2 \%$ very fine sand, which originates from the Amazon River. Due to the continuous alternation of compression and decompression caused by the waves, the clay can be stirred up. The fine particles are transported to the west by weak currents, the sand grains settle down again. In this manner sand is concentrated at the surface. Chenier formation under these circumstances begins at about low water level. Due to the very fine grainsize of the sand, the cheniers are much flatter and they show ripples on the foreshore (Figure 18).

In periods of severe erosion, coastal retreat can go so far that an old chenier is reached, which starts to function as a local sand source. Under these circumstances a sand accretionary coast will develop. A number of chenier ridges is formed, one after another, in seaward direction. Beyond backward bending parts of the coast, spits develop, e.g. at Braamspunt. These beaches often show rhythmic features like beach cusps (Figure 19).

\section{?.3 Mangroves as sustainable coastal defence}

It has been claimed that mangroves provide protection against waves (Mazda et al. 1997; McIvor et al. 2012), storm surges (Zhang et al. 2012) and tsunamis (Danielsen et al. 2005). This is correct in the sense that they absorb energy from these floods. But they will be uprooted and washed away nonetheless when subjected to repeatedly breaking waves (Figure 20) or to a single violent flood, leaving a more vulnerable coast for the next decades. Of course, the piles of uprooted trees on the shore themselves also form a hindering for waves and currents and contribute to coastal protection (Figures 11 and 20b).

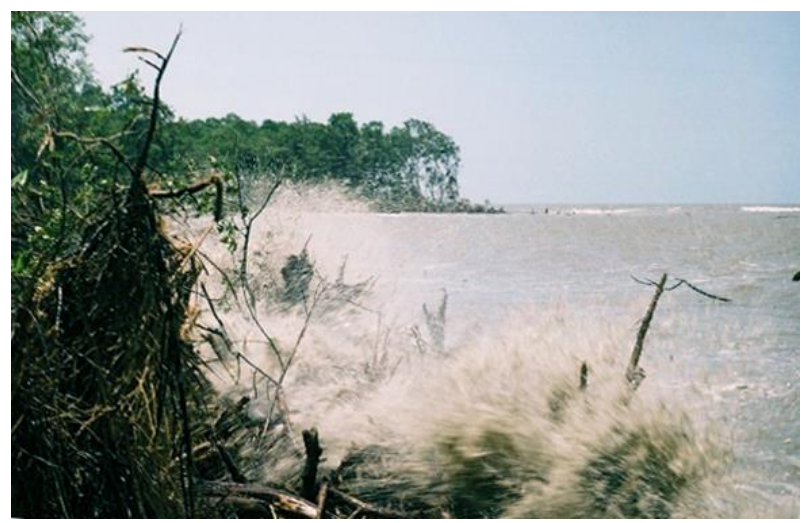

Figure 20 Left: Waves impacting on the Suriname coast. (Credit: S. Naipal) - Right: Uprooted black mangroves along the Suriname coast (2002). (Credit: E. Toorman)

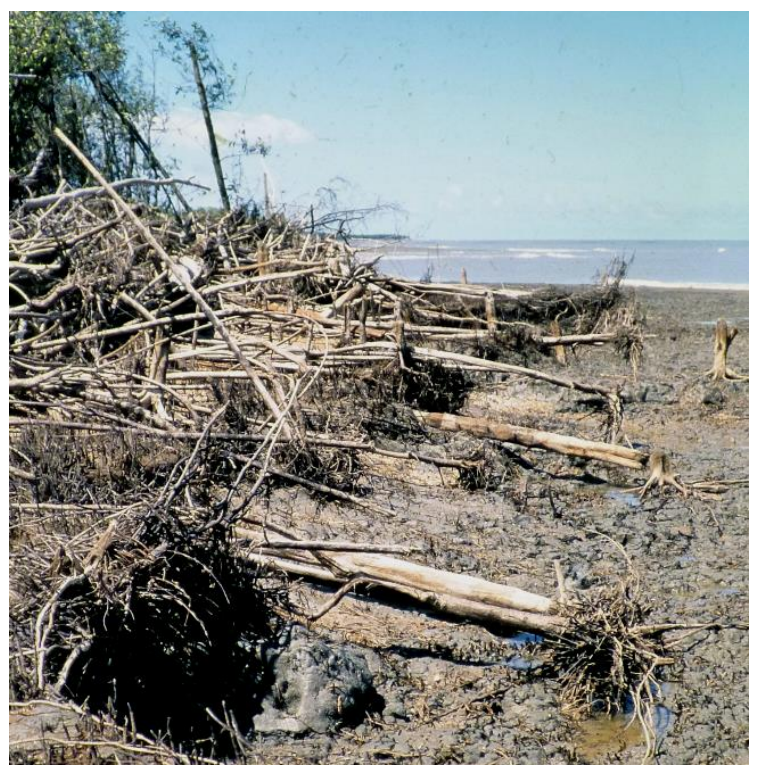


The 2004 Indian Ocean tsunami in particular raised a discussion on the effectiveness of mangroves, mainly resulting from interpretations of the data which did not account for all factors. Eventually this debate was settled with a common publication (Feagin et al. 2010). However, the important role of the sediments has not been considered.

\section{?.3.1 The physical functioning}

To understand how mangroves can act as coastal defence, it is necessary to look at the interaction between three key players: the trees, the sediment and the hydrodynamic forcing. The functioning can only be understood by considering the interaction between each of these three and their combined effects.

\section{?.3.1.1 Interaction between mangroves and hydrodynamics}

Many studies exist on how vegetation reduces the energy from currents and waves (Mazda et al. 1997; McIvor et al. 2012). In the case of mangroves, the vegetation can be considered rigid. Energy is dissipated by friction with the stems and, in the case of Avicennia, the pneumatophores, which implies conversion of hydrodynamic energy into turbulence which eventually in its turn is dissipated by viscosity into heat. It is then evident that the degree of dissipation depends on the density of the trees and their size.

\section{?.3.1.2 Interaction between mangroves and sediment}

Like all trees, mangroves find their stability by developing an appropriate root system in the soil in which they grow and from which they extract their nutrients. Mangroves typically grow on mud deposits, to which they are adapted.

Mud usually refers to a dense sediment-water mixture dominated by clay particles. Such sediment is referred to as cohesive sediment (Mehta 2014). Clay particles in water hardly occur as individual primary particles, since they tend to aggregate and form flocs. When these flocs settle they form a so-called soil skeleton where the "particles" (i.e. flocs) are stacked and support each other, whereas the open spaces between the particles (the pores) are filled with water.

A mud deposit is sometimes compared to a card house structure or a sponge structure: a low volume of solids and a large volume of voids filled with water. But due to accumulation of sediment flocs, the skeleton is subject to an increasing load of particles and the network may deform and bonds between particles broken, such that the card house collapses. The latter goes very slowly, because the pore water needs to escape, but due to the small size of the pores, and the hydrophilic nature of the clay particles, the pore water experiences a lot of capillary flow resistance. This compaction is called self-weight consolidation (Mehta, 2014).

Black mangrove propagules can develop their roots very easily in the soft top soil of these mud banks. With the growth of the tree, the tree becomes heavier, but it manages to divide its weight over a larger area by spreading the roots in the horizontal direction. The roots do not grow deeply, because due to the low permeability of the mud, the compacting mud becomes deoxidized very quickly at $5-10 \mathrm{~cm}$ depths. This explains the more the adaptation of the root system. 
Furthermore, the mangroves-sediment entity forms an ecosystem of high biodiversity. The growth of plants and the activity of animals alter the composition, by adding organic material to the sediments, and subsequently the structure of the sediments. From studies elsewhere, it is known that organic matter increases the strength and thus the erosion resistance of sediments.

\section{?.3.1.3 Interaction between hydrodynamics and sediment}

Realizing the cohesive nature of the sediments, one can look at the interaction between marine hydrodynamics and the sediments. The sediment deposits are fed by sediments transported by tidal and wave-induced currents. But when the wave movement is more dynamic the water can also remobilize sediments that lie between the roots. When inundated and subjected to waves, the erosion resistance of the sediment may reduce due to pore pressure build up (i.e. partial fluidization), making the sediment even more prone to erosion. Hence, mangrove trees at the seaside edge of the fringe that are most subject to waves in interbank areas are most prone to sediments weakened and eventually washed away between the roots (Figure 21), which may destabilize the tree. Indeed, it is seen that many mangroves simply tip over on the eroded shore (Figure 22).

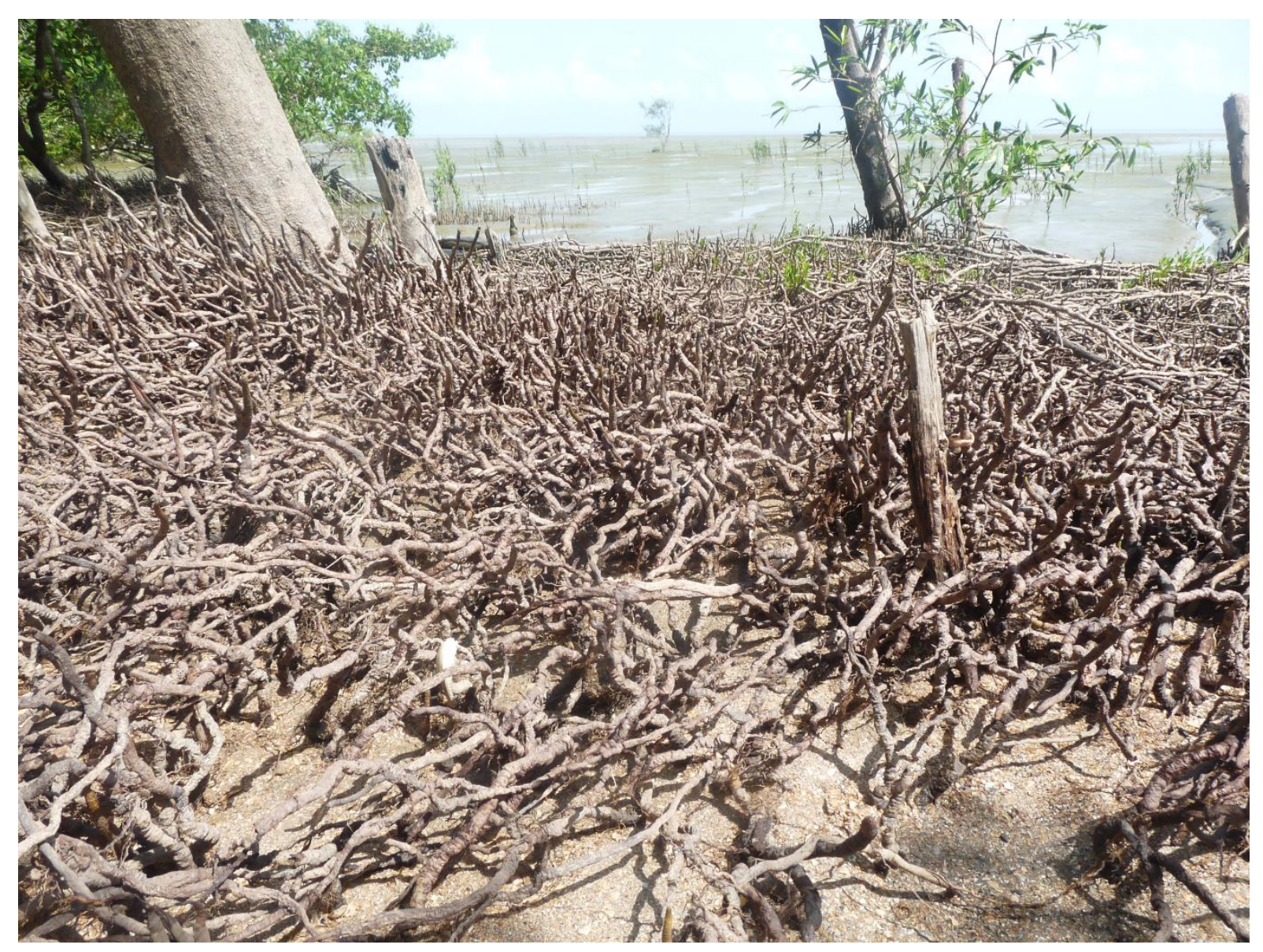

Figure 21 Avicennia roots exposed due to hydrodynamic forcing which washes away the sediments at high water (Suriname, 2011). (Credit: E. Toorman) 


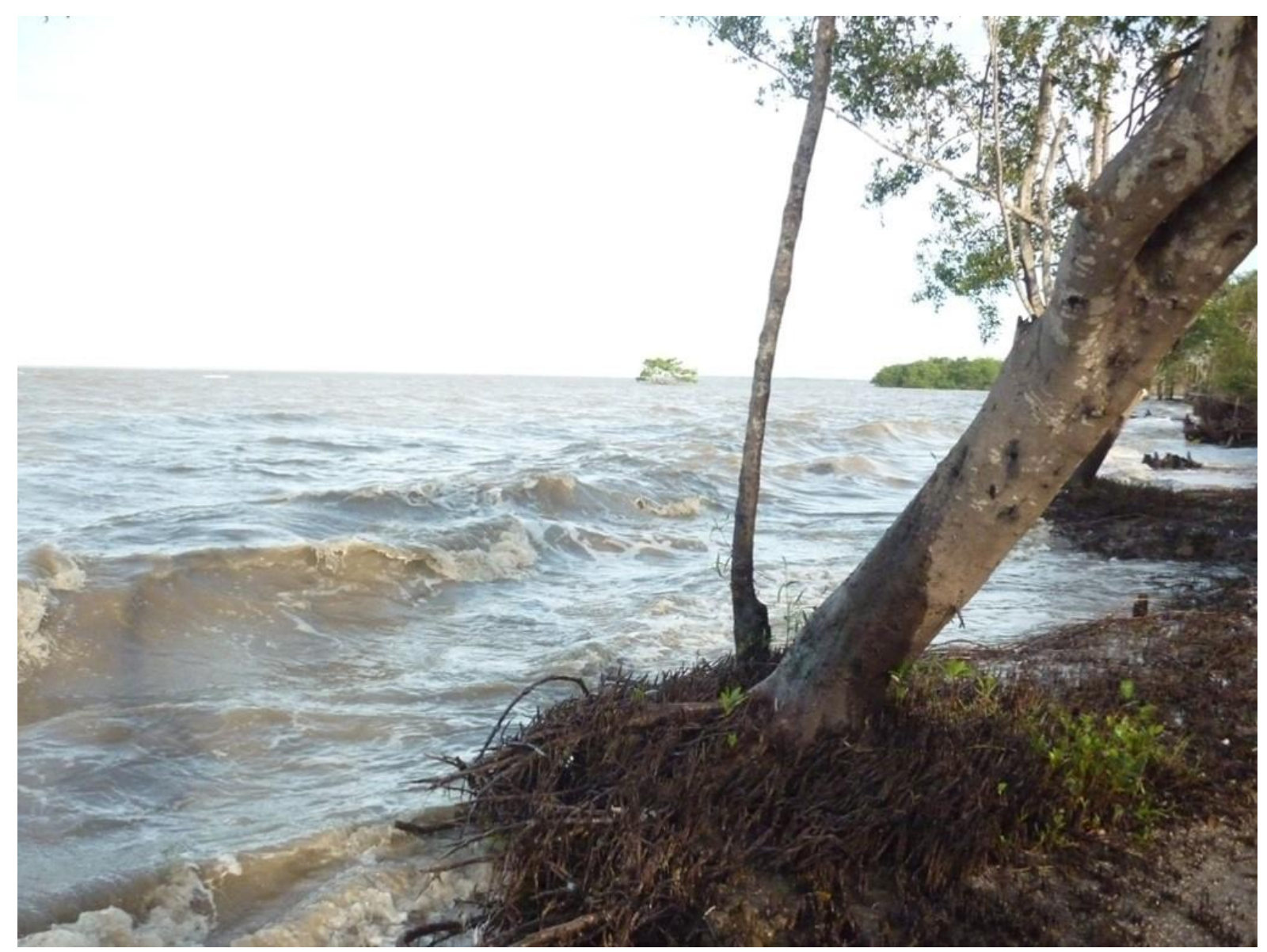

Figure 22 Avicennia tree about to tip over (Suriname). (Credit: S. Naipal)

Where there is persistent erosion, as seen for instance at the outlet of some drainage channels in Coronie (Suriname), cliff erosion can occur, which washes away even the older sediments beneath the root system (Figures 10 and 23).

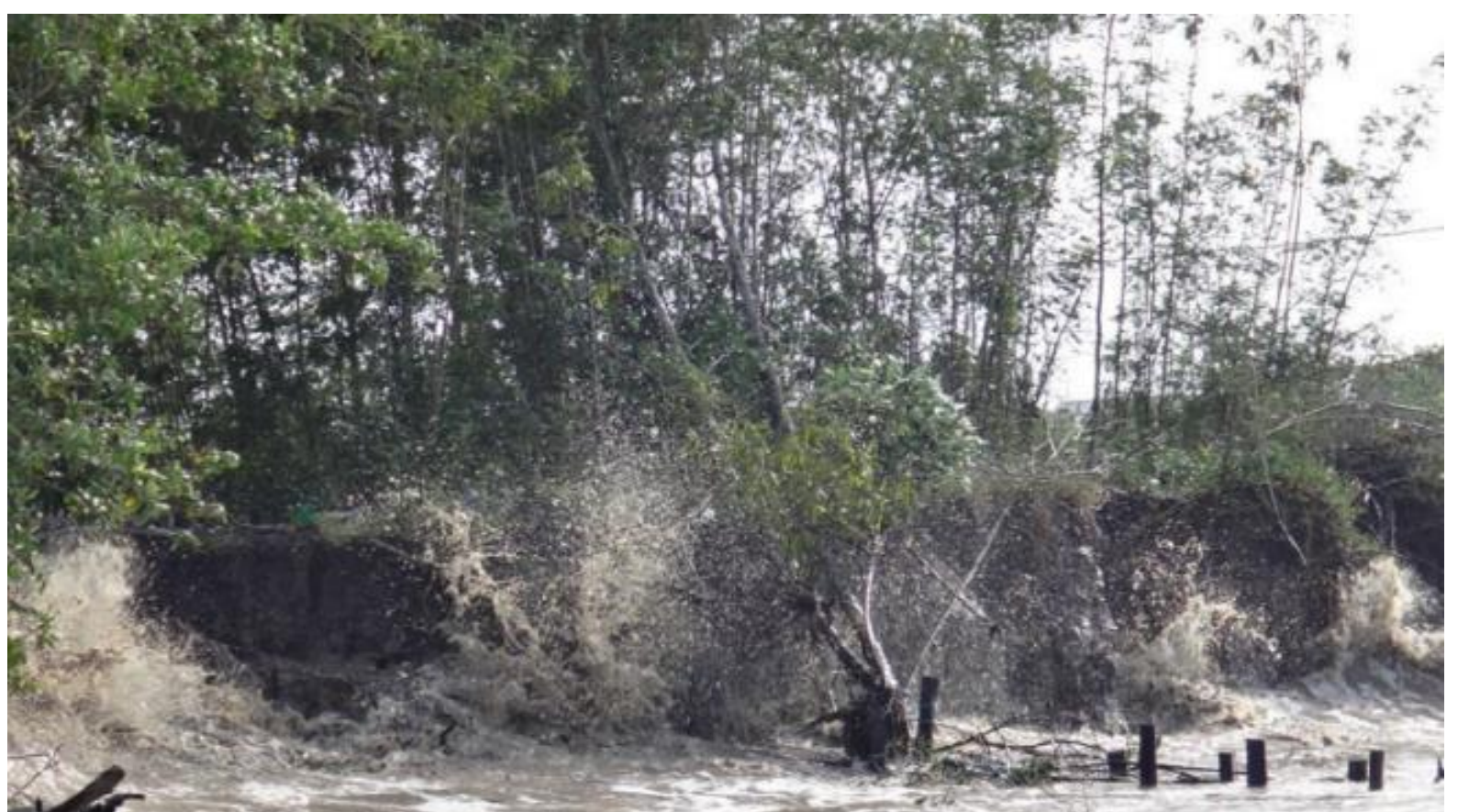

Figure 23 Cliff erosion by waves (Suriname). (Credit: S. Naipal) 
When waves move over a mud bank, the pores are subjected to an oscillating pressure field. This tends to induce pore water flow within the soil skeleton, but due to the capillary resistance, it cannot follow the frequency of the wave. This lag leads to pore pressure build-up. The resulting normal stresses counteract the effective stress due to self-weight consolidation. If the excess pore pressure becomes higher than the submerged weight of the overlying sediment (i.e. the effective stress), the bed is fluidized: the particles are pushed aside, bonds are broken and they can move relative to each other (similar to quick-sand).

At the other hand the cycle of expansion and compression of the pore pressure results in a net elasto-plastic deformation of the skeleton. The mechanical friction between the particles and the pore water flow induce energy loss. Since this energy originates from the wave motion transferred to the pore water, it therefore results in damping of the waves, when they travel over a mud bank.

Fluid mud on a slope may tend to move downhill as a visco-plastic fluid. Gratiot et al. (2007) hypothesize that this is counteracted by wave-induced drag in the wave direction (usually towards the shore). This balance may explain the cross-shore profile of a mud bank. The highest thickness is expected to occur where the waves have lost their energy.

Thus fare, wave-mud interaction had been studied with an elastic description of the deformation of the mud layer (reviewed by Mehta et al. 1994). But this is only valid for very small deformations. In this case one can compute the motion of the fluid mud layer even analytically for idealized homogeneous mud layers. These results were successfully compared to laboratory experiments (Sakakiyama and Bijker 1989).

Over a soft fluidized mud layer, the deformation results in visco-plastic flow and its nonNewtonian behaviour can be represented by a (non-ideal) Bingham rheological model (Toorman 1997). To account for the break-up and restoration of interparticle bonds, time dependence is observed of the rheological parameters. This thixotropic behaviour can be modelled with an additional kinetic equation which describes the break-up under shear and recovery of the soil skeleton structure at rest. The corresponding rheological closure (Toorman 1997), implemented into a CFD software, has been demonstrated to be able to simulate the damping by waves (Toorman 2008; Villaroel 2009). It proved to be necessary to account for an increase in resistance with self-weight compaction, i.e. the effective viscosity increasing with depth and density, in order to obtain realistic velocity profiles, as observed in laboratory experiments (Villaroel 2009).

Therefore, mangroves need shelter, which is provided along the Guianas coast by the mud banks. Waves are damped and do not reach the shore. Moreover, the mud deposit forms a low berm which canalizes the runoff from land into a creek running in front of the mangroves (Figure 24). The berm itself is also slowly colonized by propagules that get stuck on these slightly higher elevations, where optimal conditions for seedling trapping occurs (Proissy et al. 2009). 


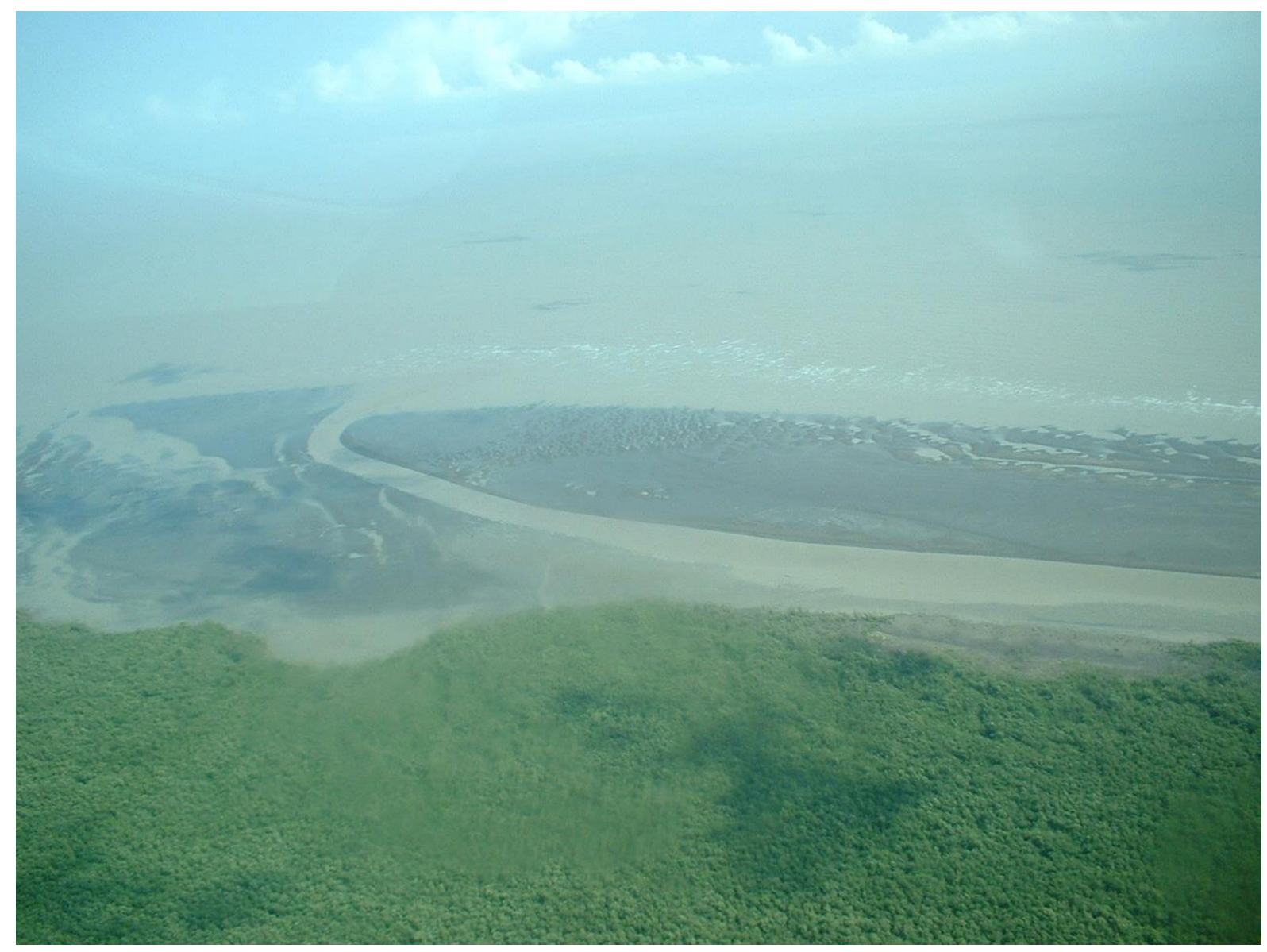

Figure 24 Head of a mud bank at low water, deflecting the runoff from land and providing shelter for the mangroves. (Credit: S. Naipal)

\section{?.4 Ecological engineering: mangrove restoration}

Efforts have been made in Guyana and Suriname to restore mangrove woods along the coast at places where the natural belt has disappeared or became too narrow to be sufficiently resilient to survive a cycle of mud bank migration. Initially, mangroves have been planted only in the swamps behind the former coastline, where the vegetation had been degraded (Augustinus, pers. comm.). Rehabilitation on the intertidal mud flats, where the plants are subject to the forces of waves and currents has only recently been tried, with mixed success.

Worldwide, a lot of mangrove restoration projects have failed, often by lack of understanding the proper conditions for development and growth (Ellison 2000; Winterwerp et al. 2013).

Local ecological experts expressed their low confidence in the success of mangrove rehabilitation along the Guianas coast, simply because there are sufficient propagules and the necessary dispersion by currents and waves is favourable, distributing them along the entire coast (Erftemeijer and Teunissen 2009). They concluded that if natural regeneration does not occur in certain places, it implies that the local conditions are unfavourable and one should not expect that planted mangroves will survive. Therefore, the first key to mangrove restoration projects is to understand the local conditions. Once the unfavourable conditions are understood, one can try to design a methodology to change the local conditions to favourable ones. 


\section{?.4.1 General principles}

Consultation of various international experts and lessons learnt from other restoration projects elsewhere in the world eventually helped to develop a general strategy (Field 1999; Lewis 2009; Winterwerp et al. 2013).

Prior to the design of a suitable rehabilitation strategy, a study has to be made in order to understanding the ecology of the local mangrove species, i.e. reproduction patterns, propagule distribution and conditions for seedling establishment and growth. A model for the dynamics for the Guianese mangroves has been proposed by Fromard et al. (2004) Figure 25. Next, one has to understand which conditions prevent the natural regeneration of mangroves in the problematic areas.

To rehabilitate a target area, first the optimal natural conditions have to be restored. This involves measures to improve the hydrological conditions (i.e. ensuring fresh water runoff and restoring tidal creeks) and the onshore sediment fluxes. Secondly, it requires a large enough buffer zone to give sufficient flexibility to overcome periods of degradation during storms or of absence of soft mud banks (interbank periods). Since sufficient propagules are available along the Guianas coast, actual planting then should no longer be necessary.

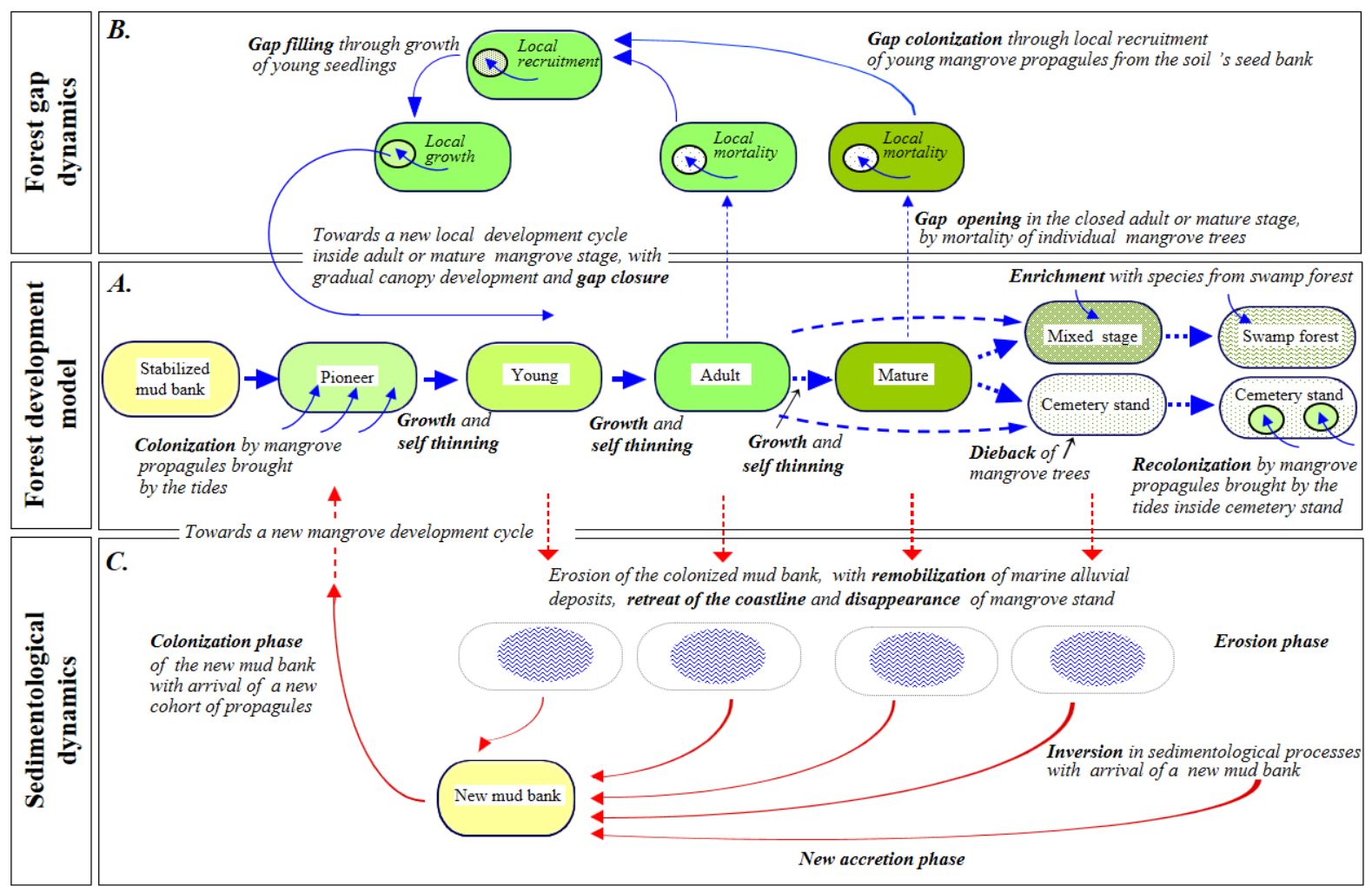

Figure 25 A combined model of Guianese mangrove dynamics. (A): Forest development model, mainly based on growth and self-thinning processes. (B): Forest gaps dynamics, brought about by local decaying and death of individual mangrove trees (adapted from Duke 2001). (C): Sedimentological dynamics, the major driving force along the coastal area under Amazonian influence. (Fromard et al. 2004)

The main challenge along the Guianas coast is to provide conditions that allow mangrove regeneration during interbank periods in areas where the minimal width of the mangrove fringe is below the critical size, which is estimated to be of the order of $1 \mathrm{~km}$, while the width of a 
resilient coastal fringe should be of the order $5 \mathrm{~km}$ (Anthony and Gratiot 2012). Since there is no shelter provided by an onshore mud bank during this period, artificial shelter has to be provided which allows entrapment of sediments and reduces wave action (by reducing wave heights by damping and reducing wave reflection).

Sediment entrapment areas are well know from saltmarsh works (Winterwerp et al. 2013). The latter type is based on its successful use centuries ago for the creations of polders in the Netherlands. They consist of areas enclosed at both cross-shore boundaries, reducing longshore currents within the unit, and seaside boundary, reducing wave action and tidal currents. Fine sediments can settle and deposit more easily under these quitter conditions. Moreover, cohesive sediments can form larger flocs, which settle faster (Mehta 2014).

\section{?.4.2 Guyana Mangrove Restoration Project}

The Guyana Mangrove Restoration Project (GMRP - www.mangrovesgy.org) commenced in 2010 and was co-financed by the Government of Guyana and the European Union under the Global Climate Change Alliance. The Project was implemented by the National Agriculture Research and Extension Institute (NAREI) with support from a multi-agency oversight committee known as the Mangrove Action Committee. Following the completion of the project phase in 2013, the Government of Guyana committed to continued mangrove restoration and management, and the Project Unit was integrated into the NAREI structure (NAREI 2014).

GMRP adopted a multidisciplinary approach to mangrove restoration, protection and management. This included restoration through the use of coastal engineering structures and seedlings, enforcement by rangers, community development and alternative livelihoods, research and development and public awareness and education.

\section{?4.2.1 Mangrove restoration interventions implemented under GMRP}

Guyana adopted the principles of Ecological Mangrove Restoration (EMR) (Lewis III 2004) to design and implement its mangrove restoration program following failed attempts at restoration primarily through seedling plantations at the beginning of the project.

A range of interventions aimed at restoring degraded coastal mangroves and creating a suitable environment for mangrove to colonize the coastline were implemented as part of the mangrove restoration programme. These interventions included:

- Mangrove seedling planting

- Construction of coastal infrastructure such as groins and breakwaters

- Spartina grass planting

- Construction of restrictive gates and fences to reduce the impact of anthropogenic activities

\section{?4.2.1.1 Mangrove seedling planting}

Seedling planting is only possible in areas or sites that have a suitable mud elevation. Based on the most successful sites and comparison of natural forest, NAREI has established a suggested guideline range for planting Avicennia germinans based at $2.3 \mathrm{~m}-2.7 \mathrm{~m}$ above chart datum (Landell Mills Limited 2013). Only the Avicennia germinans species is planted based on the natural zonation pattern in Guyana. 
From 2010-2016 over 500,000 mangrove seedlings were produced in community nurseries and planted in sixteen villages along the coastline (Figure 26).

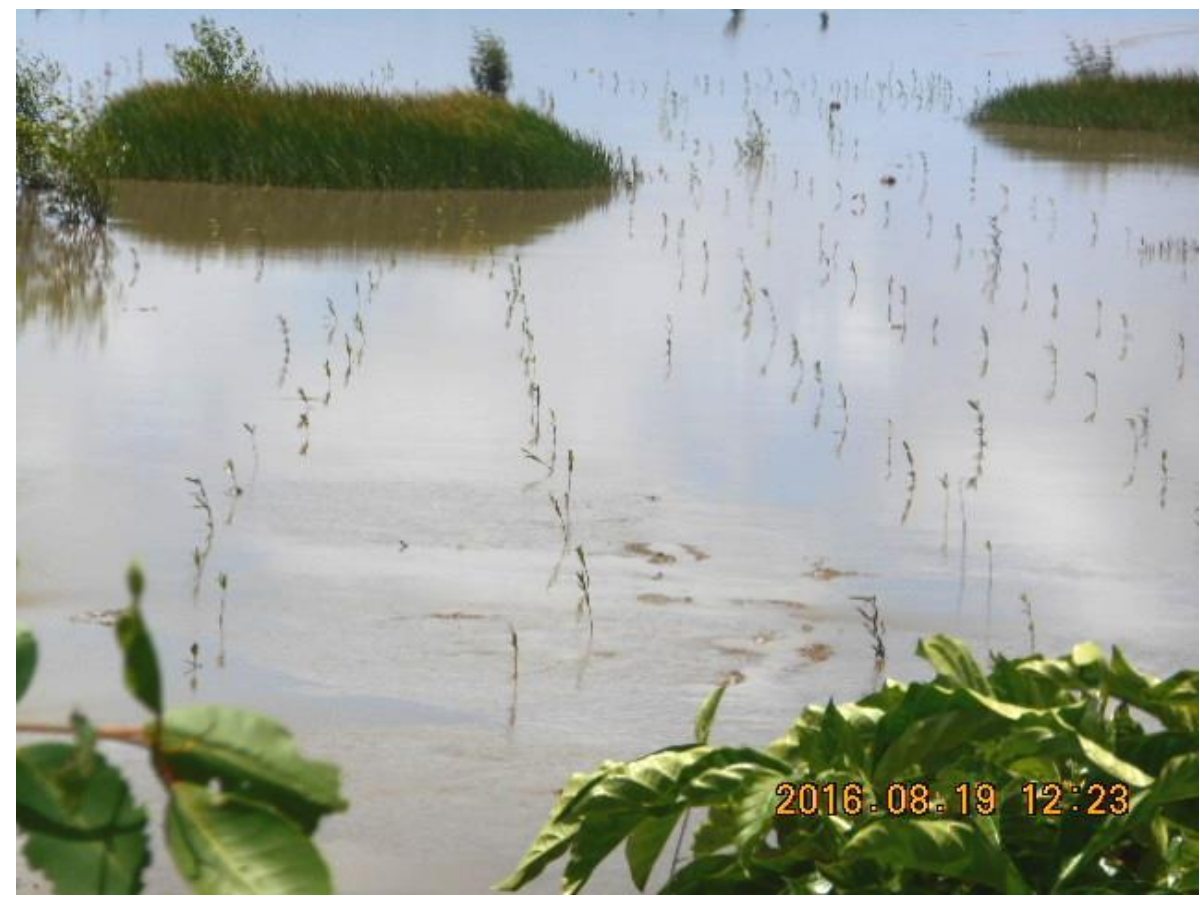

Figure 26 Avicennia germinans seedlings planted along the Better Hope coastline, East Coast Demerara (Guyana), August 2016. (Credit: R. Adams, NAREI)

Initial efforts of restoration were unsuccessful due to limited local expertise. The success rate increased during the second year of project implementation following the fielding of technical experts and training of local project team. Detailed site assessments where introduced and pre-planting surveys and surveys of the topography of both successful and unsuccessful planting areas showed that surface elevations of unvegetated mudflats needed to in the range of $+2.0 \mathrm{~m}-+2.5 \mathrm{~m}$ MSL in order to support planted mangroves (Landell Mills Limited 2013). Following the guiding principles of EMR, seedling planting was only utilized to increase recovery time of a site that met the necessary criteria to support restoration.

Field monitoring of planted restoration sites (Figures 27-30) facilitated a comprehensive statistical analysis for survival and growth rates. Assessments completed (Machin and Lewis III 2013; Adams 2014) indicated that survival rates and growth varied among restoration sites and can be grouped into three scenarios:

1. Fast growing and high survival (Wellington Park, Village \#6-8, Chateau Margot, Success, Lima, Better Hope). Mud elevation $2.13-2.49 \mathrm{~cm}$ above CD;

2. Slower growing and high survival (Greenfield, Hope Beach, Le Ressouvenir, Felicity). Mud elevation $1.61-2.37 \mathrm{~cm}$ above $\mathrm{CD}$;

3. Low or no survival (Hope, Greenfield, Victoria, Section C Enterprise, Mon Repos, LBI/Triumph, Buxton, Nooten Zuil, Lusignan). Mud elevation 1.9 to $2.4 \mathrm{~m}$ above CD.

Research completed by Robertson (2014) on the protective capacity of the restored Chateau Margot/Success restoration site indicated that a three year old black mangrove forest with a bandwidth of $50 \mathrm{~m}$ can reduce a $0.43 \mathrm{~m}$ wave at open sea to $0.001 \mathrm{~m}$ at the coast. Modelled wave heights prove that a $50 \mathrm{~m}$ mangrove forest can reduce a $0.43 \mathrm{~m}$ wave to approximately $0.2 \mathrm{~m}$ (Robertson 2014). 


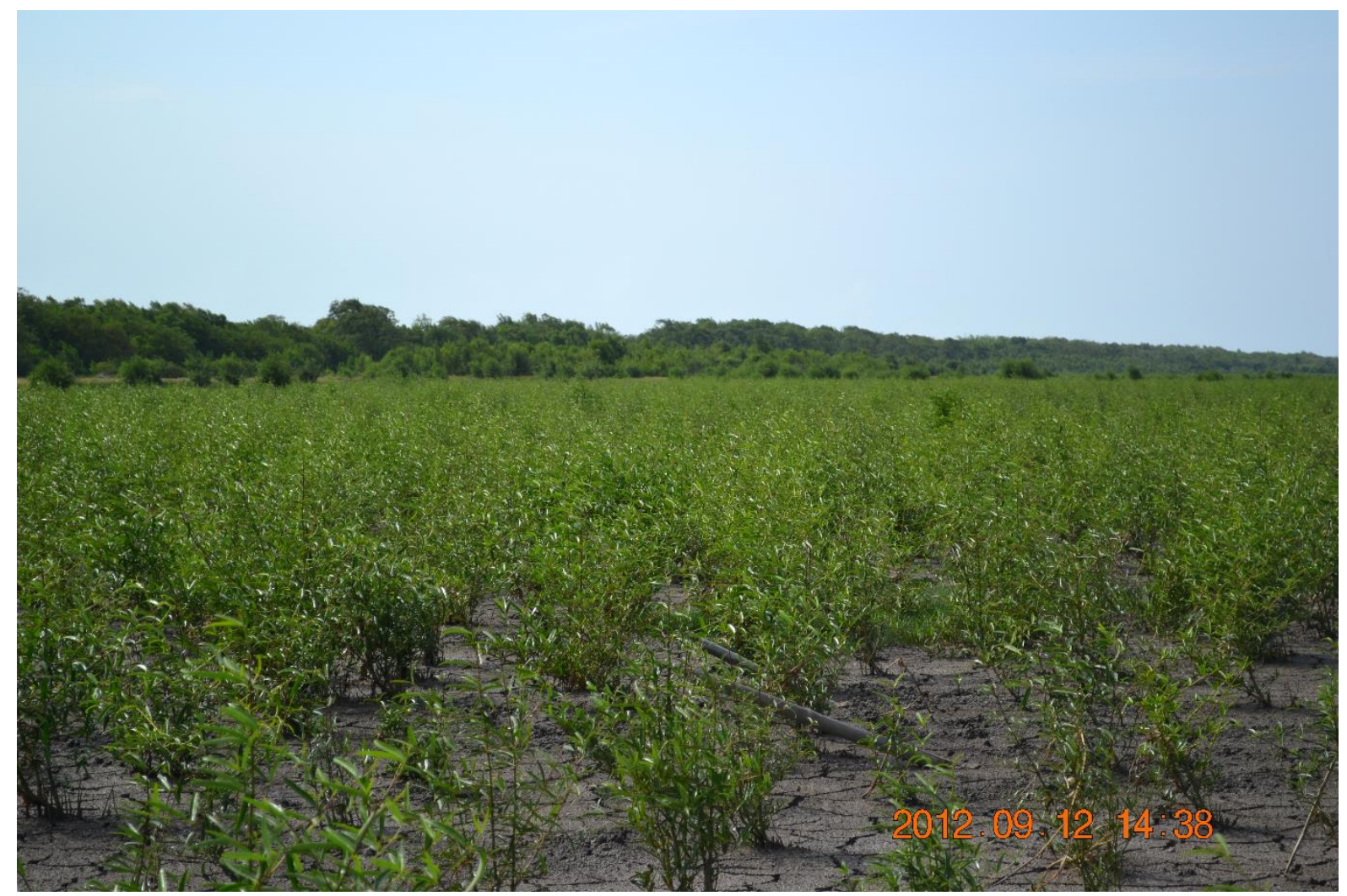

Figure 27 Planted black mangrove seedlings along the foreshore of Village \#6-8, West Coast Berbice (Guyana), Region 5. The site was planted in 2011 and 2012. (Credit: K. Moseley, NAREI)

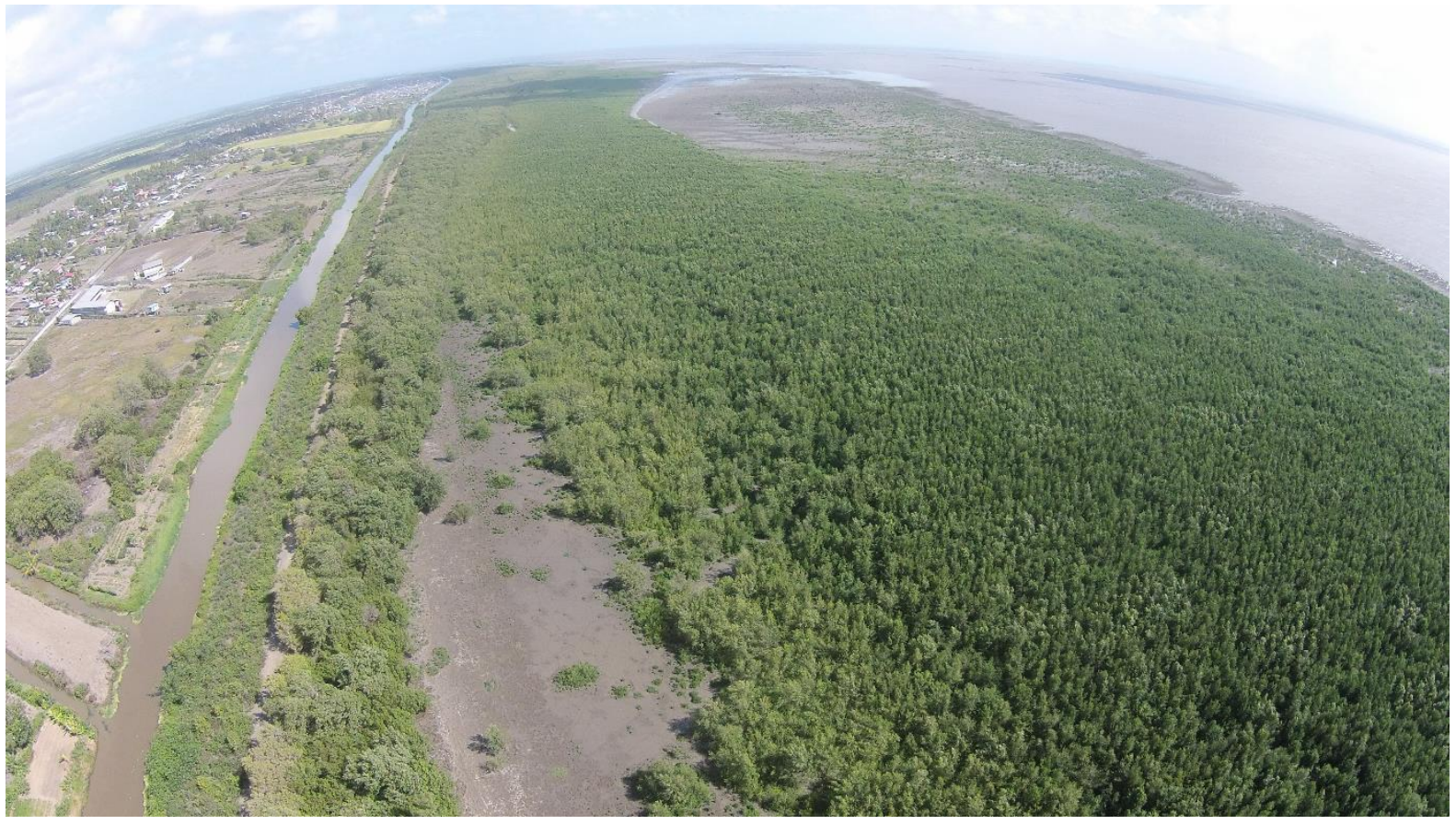

Figure 282016 aerial of Village \#6-8, West Coast Berbice (Guyana), planted in 2011 and 2012. Successful planting of black mangrove seedlings resulted in extensive natural regeneration. (Credit: C. Gittens, WSG) 


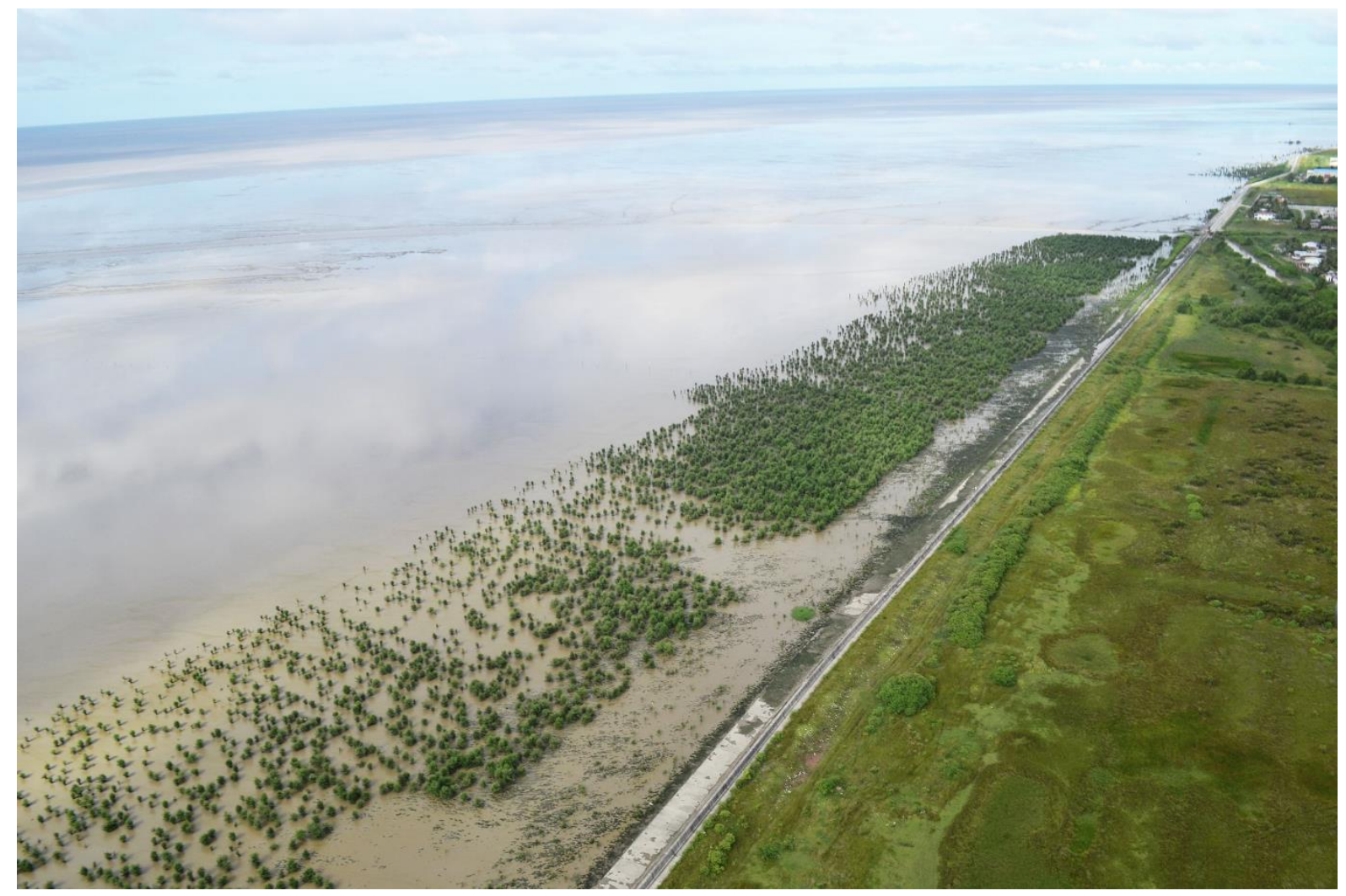

Figure 292012 aerial of planted black mangroves along the coastline Felicity to Chateau Margot (East Coast Demerara, Guyana), Region \#4. Site was planted in 2011 and 2012. (Credit: I. Brierley, CATS)

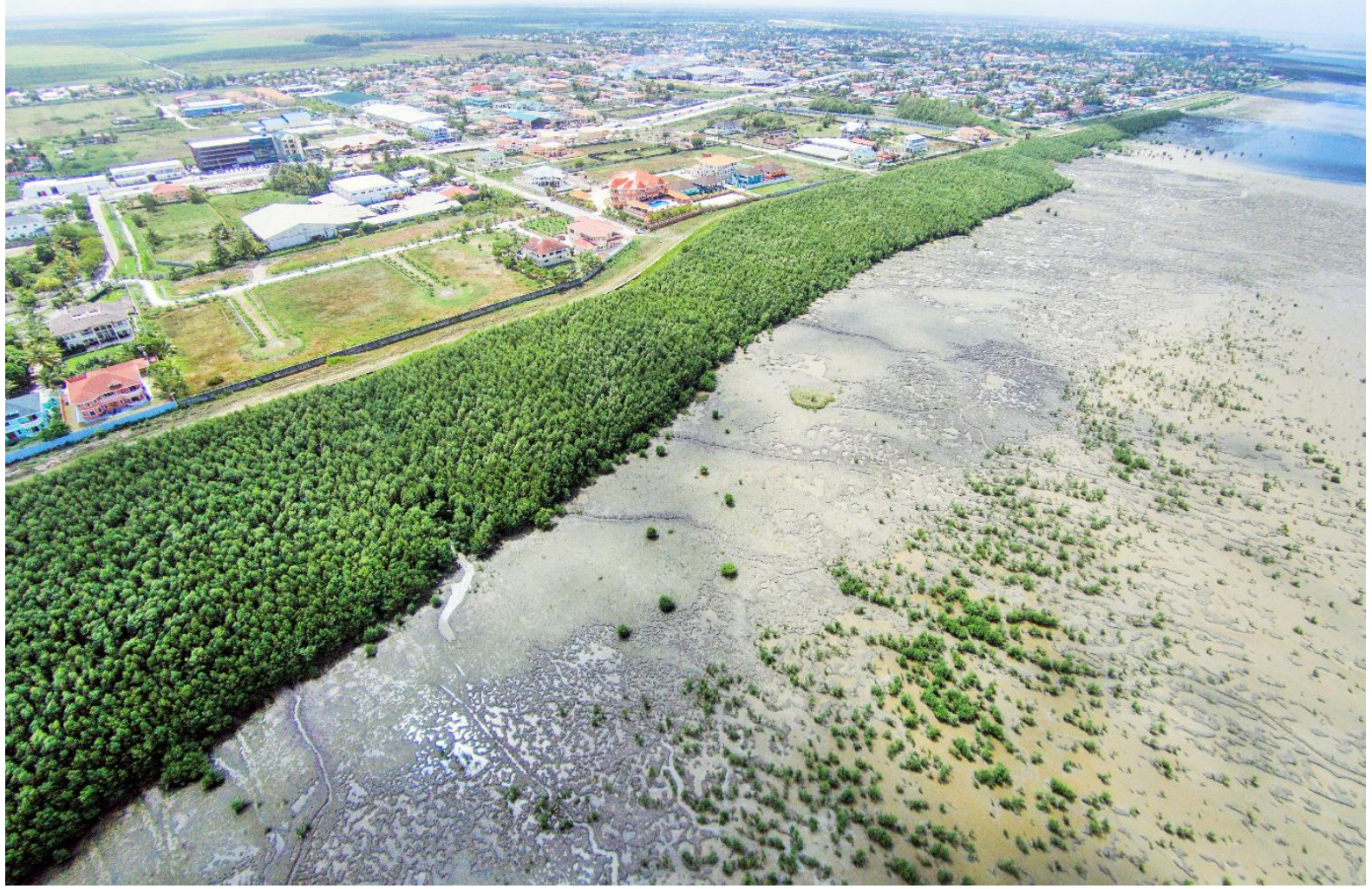

Figure 302015 aerial of restored black mangrove with extensive natural regeneration along the coastline Felicity to Chateau Margot (East Coast Demerara, Guyana), Region \#4. (Credit: I. Brierley, CATS) 


\section{?.4.2.1.2 Coastal engineering interventions}

Coastal engineering interventions were implemented at sites along the coast to encourage accretion. These interventions aim to create a suitable environment that will encourage mangrove restoration by increasing shoreline elevation.

Following collaboration with the Guyana Sea and River Defence Division, three options for construction of low-cost coastal structures was developed using the following technologies: geotextile tubes, brushwood dams and rubble mounts.

Geotextile tube technology was implemented at two sites to form a detached offshore breakwater and a groin. Two geotextile tube projects were completed at Devonshire Castle in Regions No. 2 and Victoria in Region No. 4. Spartina grass was introduced at both sites following completion of the structures to support soil consolidation.

Brushwood dams were constructed using locally available building material i.e. bamboos (Figure 31). The brushwood dams were designed to mimic the mangrove roots by trapping sediments thus increasing shoreline elevation. Brushwood dams were constructed at three locations in Region \#2 and Region \#4 in 2013, 2015 and 2016. Iron bamboos were used as piles ranging from 10 to $15 \mathrm{~cm}$ in diameter and having lengths between 7 to $9 \mathrm{~m}$. Brushwood dams were filled with bundles of bamboos of the same size to that of the bamboo piles to complete the system.

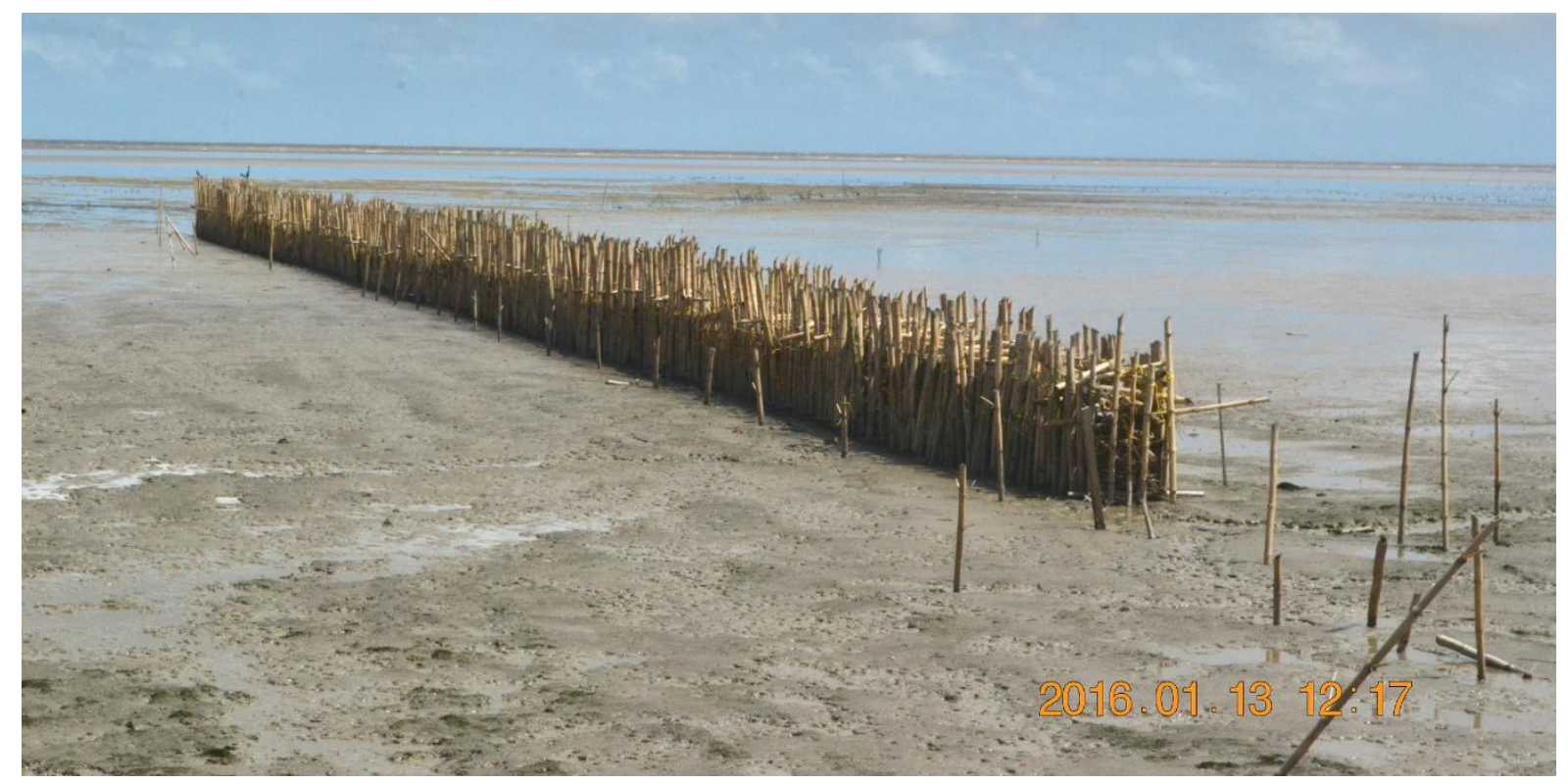

Figure 31 Brushwood dam constructed at Walton Hall (Essequibo Coast, Guyana), Region No. 2 in 2015. (Credit: L. Jack, NAREI)

The result of the impact of coastal structures on mangrove regeneration is expected to be a continuous long term study. Data collected on structures are varied. Results indicate that structures placed at a site with a visible mud bank offshore and experiencing accretion, have greater potential to trap sediments and increase elevation. Critical to the success of coastal structures is the completion of geotechnical surveys to ensure design parameters are suitable for the foreshore characteristics. Geotextile groin constructed at Devonshire (Figure 32) showed the best results in relation to changes to the shoreline line conditions and rapid colonization of planted Spartina and mangrove seedlings. While there has been significant consolidation of the soil at this site, elevation taken at two periods showed a marginal decrease 
in elevation within a six month period from $2.39 \mathrm{~m}$ to $2.35 \mathrm{~m}$ above chart datum (CD). This was due to consolidation of the soil.

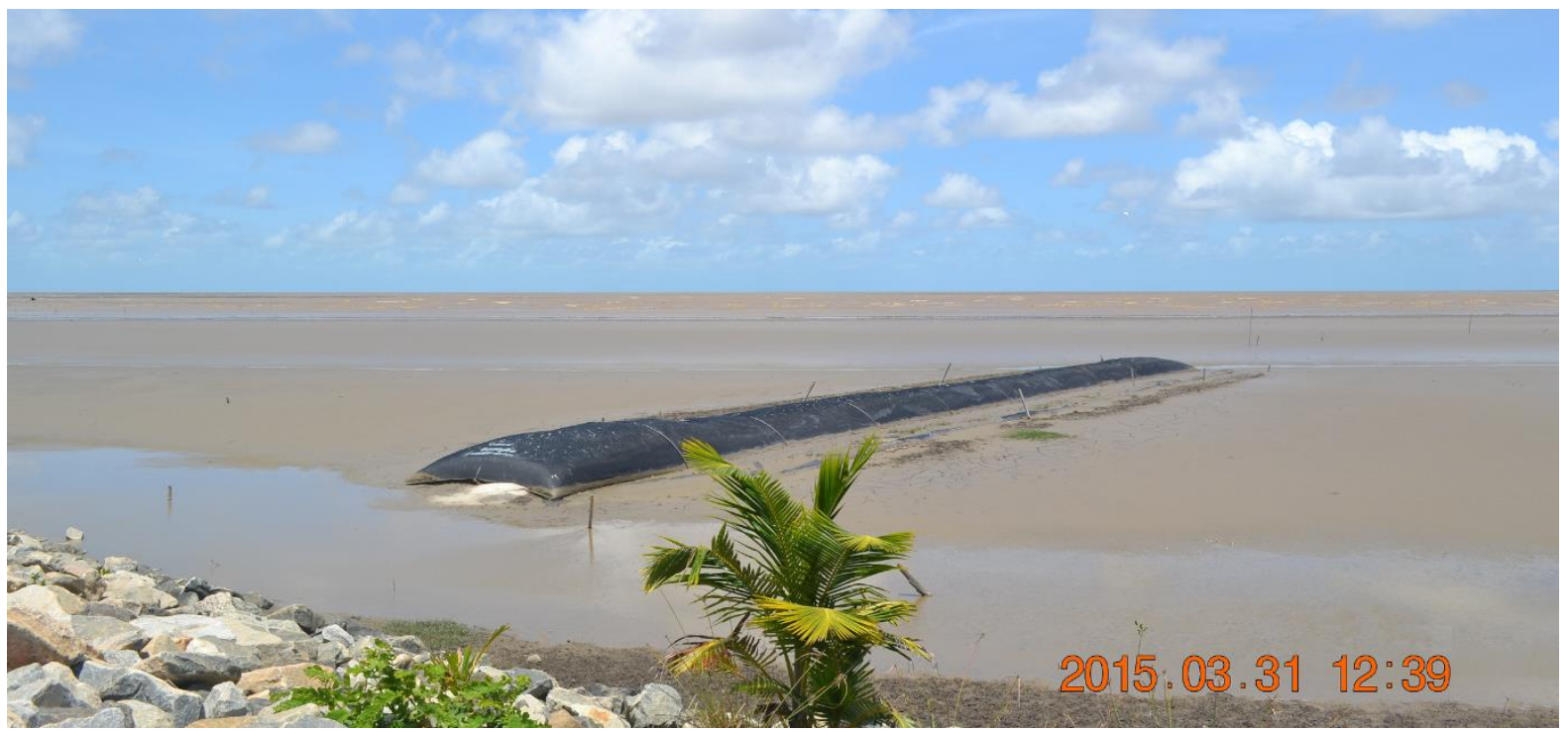

Figure 32 Site conditions following completion of a geotextile tube groyne at Devonshire Castle (Guyana), Region 22014. (Credit: L. Jack, NAREI)

\section{?.4.2.1.3 Spartina grass planting}

In 2013 the GMRP implemented a new restoration strategy for sites along the coastline where mangrove planting was not suitable due to poor mud consolidation and low elevation. The Spartina brasiliensis (Raddi) is one of the lesser known coastal salt marsh species along Guyana's coastline. The presence of Spartina brasiliensis beds in Guyana has been described as occurring on raised areas on nearshore mud banks where the grass quickly establishes, develops into large clumps and raises the level of the mud to form large stands. These stands are then typically colonised by Avicennia and Laguncularia mangrove species, after which they eventually disappears beneath these forests (Machin 2012).

Spartina was planted to stabilize sediments and support accretion. The use of the Spartina was introduced late in the project implementation as it was not a part of the original project plan and was a relatively new concept to the local project team. Following a technical mission from restoration expert Robin Lewis this intervention was introduced and has been incorporated into the restoration program. Spartina, which is native to the Guyana coastline, was transplanted to nine sites along the coast which did not meet the criteria to support mangrove restoration due to poor consolidation.

The grasses planted have had mixed results. Grass planted at BV/Triumph, Kilmarnock and Walton Hall was affected by heavy waves, Sargassum and livestock grazing. However Spartina planted at Victoria, Village \#6-8, Devonshire Castle and La Belle Alliance have been more resilient and have extended the area coverage significantly (Figure 33). Combining Spartina brasiliensis with structures has shown tremendous effects at sites where implemented (Figure 34). The soil consolidation at these sites also improved significantly in a short period. 

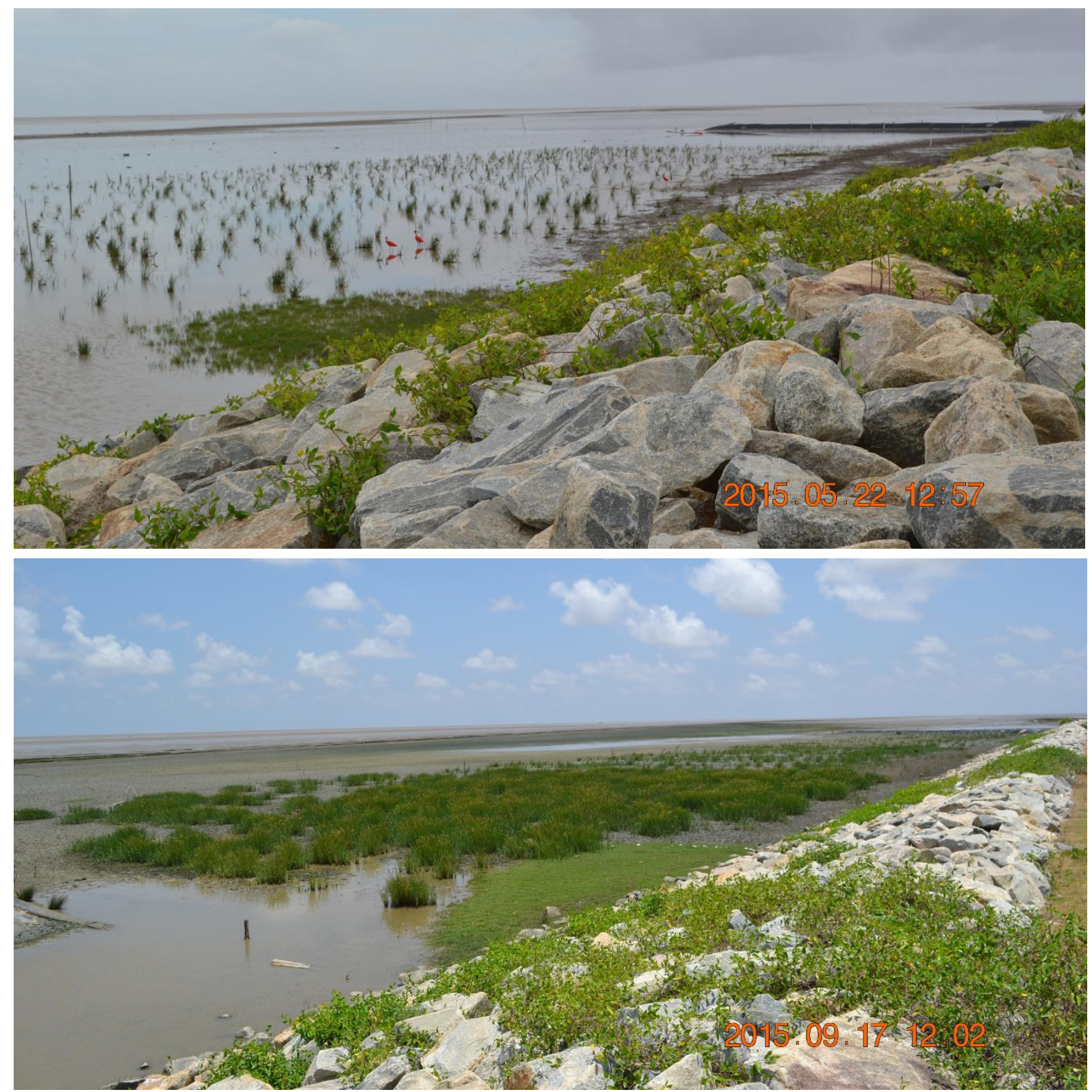

Figure 33 Top: Devonshire Castle shoreline (Guyana) was planted with Spartina in May 2015 following construction of geotextile tube. Bottom: Rapid colonization of Spartina within five months. (Credit: R. Adams, NAREI)

\section{?4.2.1.4 Challenges}

While the mangrove seedling planting program was deemed relatively successful (Topper 2012), assessments conducted revealed that there are limited sites available that are suitable for mangroves to colonize. Site assessments indicated that the elevation was either too low to support mangroves or the sediments on the shoreline was too fluid and not consolidated enough to support young seedlings.

The importance of mud bank movement along the coast of Guyana and its influence on mangrove management and restoration has been recognized and documented (Gratiot 2011; Welage 2005). However due to limited research on the movement and mapping of mud banks along coastal Guyana, the project continues to be challenged to effectively plan restoration activities based on definitive data on the current and future location of mud banks. 


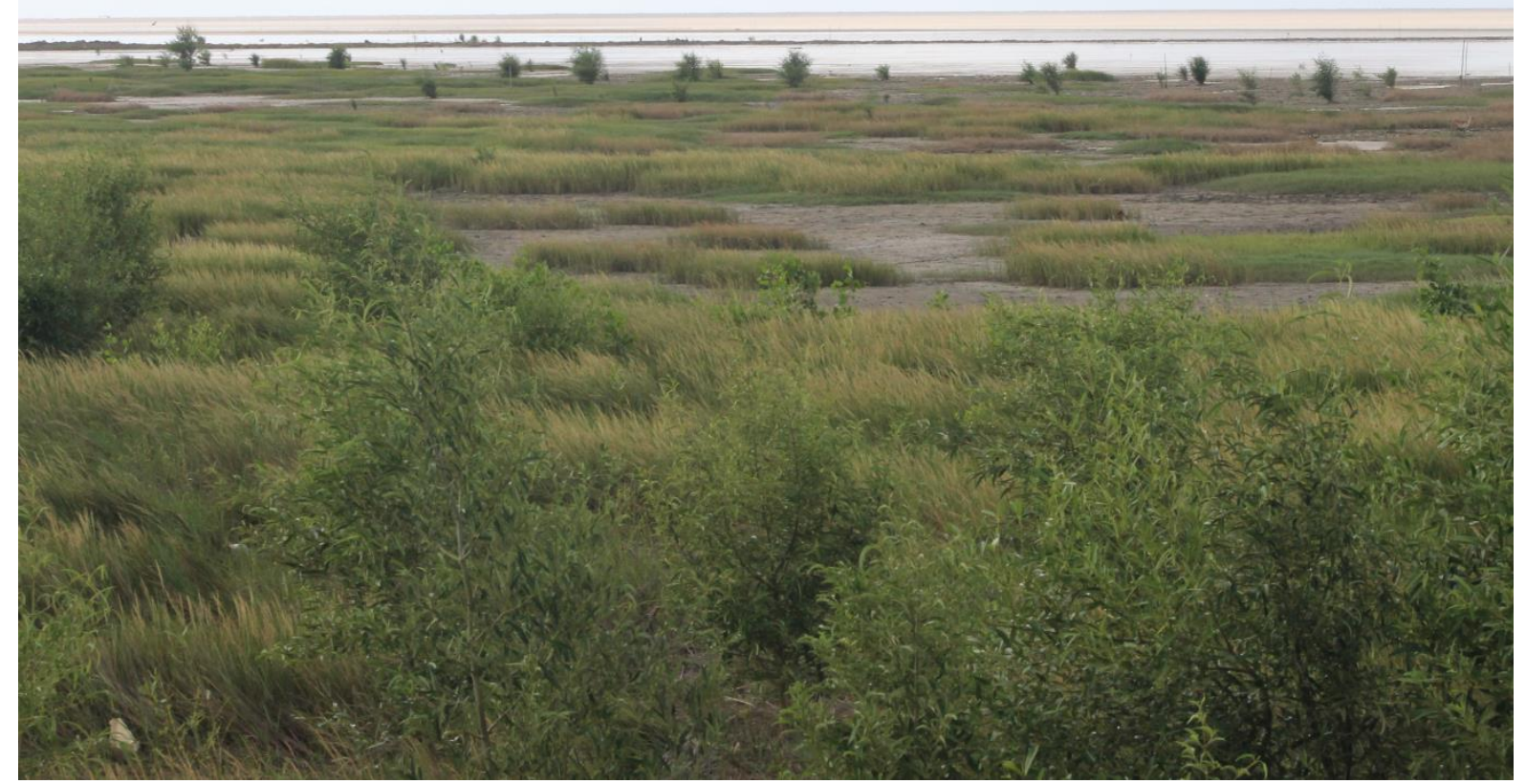

Figure 34 Natural colonization of black mangrove seedlings within Spartina grass at Devonshire Castle (Guyana), December 2016. (Credit: L. Jack, NAREI)

\section{?.4.3 Mangrove rehabilitation in Suriname}

\section{?.4.3.1 Experimental pilot project in Moy (Coronie district, Suriname)}

From 2010 to 2013, an original pilot project by AdeKUS, mainly financed by the Suriname Conservation Foundation, was set up in Moy, along the Coronie coast to plant mangroves on a bare mudflat, the front of a newly arriving mud bank, and study the conditions. The planting and monitoring was done using mud sledges, as used by the local crab hunters. It was noticed that the small plants, grown in a nursery, where not resistant to the force of inundating water. But they were also too heavy to remain vertically upright in the upper mud layer. They tend to sink to a depth where oxygen is depleted which implies the death of the mangrove. Therefore, the young plants where fastened on a stick which was put deep enough in the mud (Figure 35). This allows the root system to develop and establish the natural equilibrium between the extend of the root system, the weight of the plant and the condition (i.e. compaction) of the sediment. This also protected the plant against being washed away.

This project continued until the natural colonization of the new mud bank overtook the experimental site. It could not be determined whether the plantation experiment had any influence on the colonization speed of the natural process. From the point of view of the abundance of propagules, one would not expect so. But the existing plantation may have speeded up the sedimentation of the migrating mud bank, allowing a faster accumulation of fresh mud at the optimal elevation for propagules to settle. It has indeed been observed that the first seedlings settled in the cracks in the by sun desiccated mud of the highest elevations of the mudflat, between the planted mangroves. 


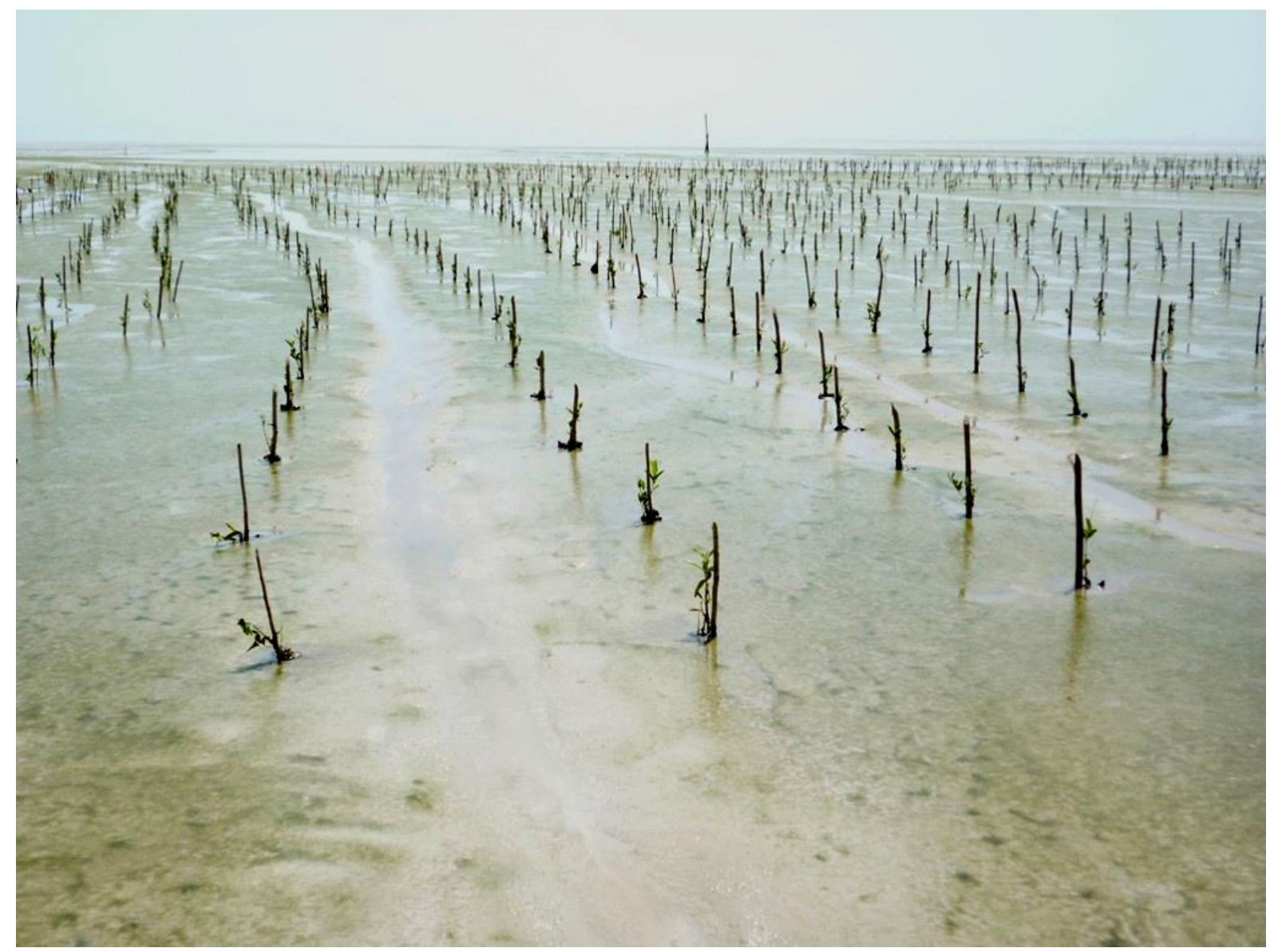

Figure 35 Young black mangrove planted and stabilized by wooden sticks along the Coronie coast (Suriname, 2010). (Credit: S. Naipal)

West of this pilot site, the Coronie sea defence wall is under construction. This walls blocks the free runoff of the inland fresh water, carrier of nutrients to potential new mangrove regeneration at the sea side. This water is collected in a ditch at the land side of the dike and can be flushed to the sea through a few gates in the wall. Therefore, dr. Naipal from AdeKUS proposed to design a water distribution system to disperse this water more equally through a permeable pipeline collector at the sea side along the entire dike (since a trench would silt up). This system has not yet been implemented and tested.

\section{?.4.3.2 Sediment trapping unit pilot project in Suriname}

A new pilot project (funded by Conservation International Suriname), based on the principles of sediment trapping units, inspired by the successful application in Indonesia (Tonneijck 2013; Tol 2016), has been implemented in 2015 at Weg naar Zee (Wanica district, near Paramaribo, Suriname), one of the most threatened coastal areas of Suriname. Here the choice went to brushwood walls forming an enclosed area over a seaward width of about 200 meter on the mud flat (Figure 36). The dam structure consists of wallaba (Eperua falcata) wooden poles (10 cm diameter), driven into the ground 2 meters deep ( $2 / 3$ of their length), spaced $0.75 \mathrm{~m}$ apart in parallel lines $0.5 \mathrm{~m}$ apart, filled with brushwood and tightened with plasticised wire. The advantage of this type of permeable walls is the fact that the sedimentrich water can enter the enclosed area where the sediments can deposit due to the much quieter 
conditions. It would actually be better to reduce the permeability close to the bottom, making sure that trapped sediment will not so easily escape with ebb currents or due to gravity currents of soft liquid mud.

The results of the first 16 months of monitoring of the sediment deposits in 9 locations in this unit shows a period of deposition (5-10 cm from June to December 2015, most of which during October-December), followed by a shorter period of erosion (most of which in January 2016: rapidly down to $+1 \mathrm{~cm}$ relative to the initial level). Subsequently gradual deposition was again observed. It is hypothesized that this alternation of erosion and deposition can be related to the on average much stronger north-eastern winds in the periods December-May, compared to the weaker, more eastern directed winds in the period June-November (NOAA Global Model wind data, averaged over the period 1997-2003; Winterwerp et al. 2005). The rapid erosion in January 2016 may indicate extreme conditions.

The following months the net deposition increased to higher levels, generating mud to the high-high waterline, reached at spring tide. Since at this elevation the fresh mud is much more exposed to drying by the sun (until the next spring tide), the material becomes much more compact and cracks are formed (Figure 37). These are the ideal conditions for mangrove propagules to develop. Natural colonization of these higher elevations has indeed started.
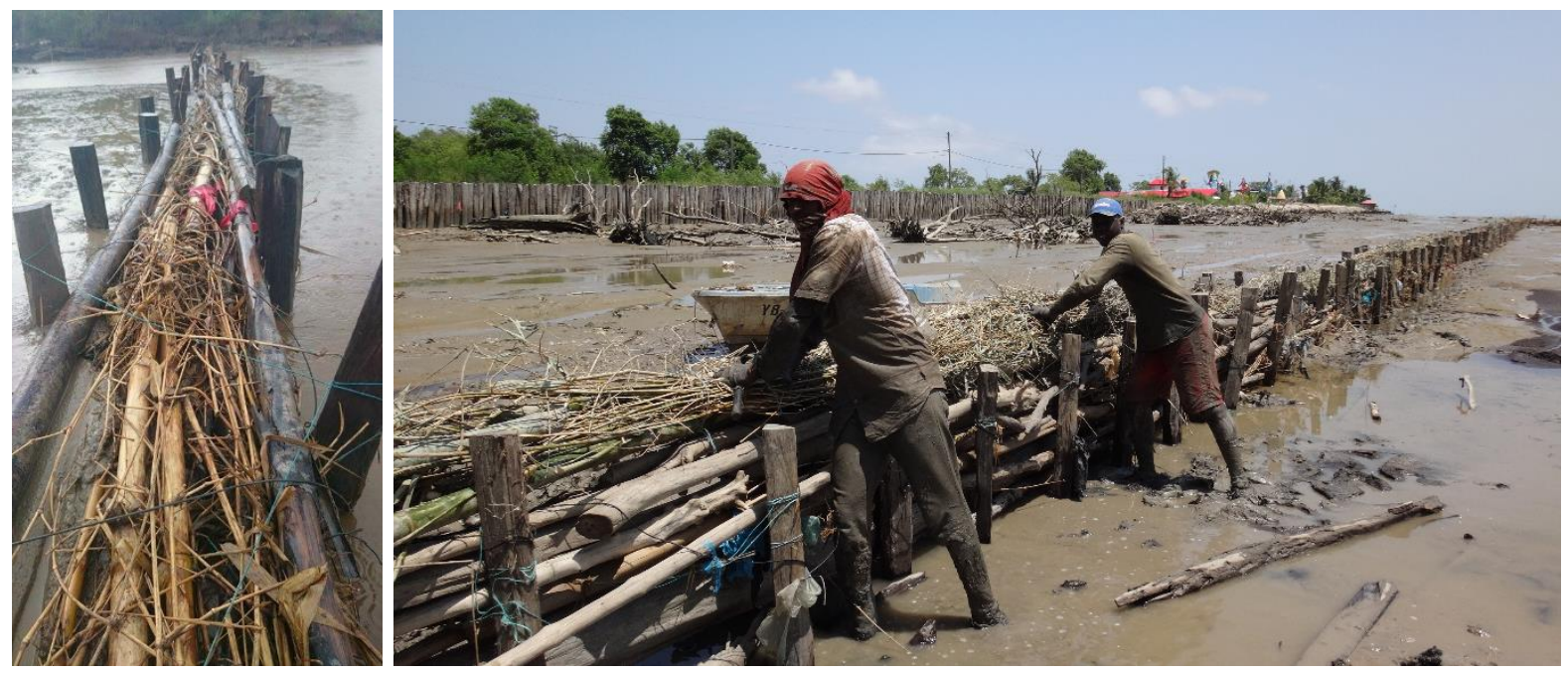

Figure 36 Construction of the sediment trapping unit at Weg naar Zee, Suriname, in September 2015. Left: top view of the dam structure (see text for details). (Credit: C. Fung-A-Loi and S. Naipal, AdeKUS)
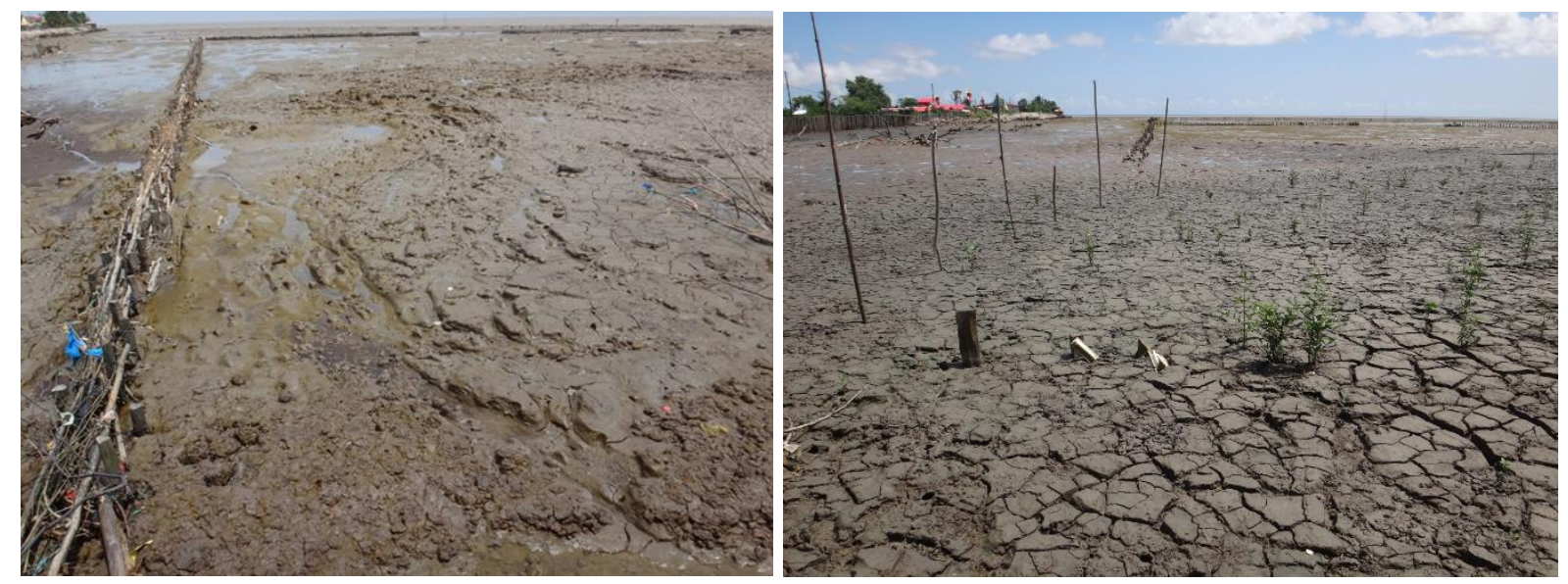

Figure 37 Evolution of the mud deposit of the sediment trapping unit at Weg naar Zee: situation in April 2016 (left) and June 2017 (right). (Credit: S. Naipal) 
The success of this STU is also explained partially by the available large sediment supply during this period, which is attributed to the approximation of a mud bank, which is crossing the Suriname river. Increased mud deposits and spontaneous mangrove colonization has been observed also a bit further to the west, but this area seems already eroding away again, indicating that the slope in front is too steep (Figure 38). Further analysis and monitoring needs to be done in order to gain better insights.

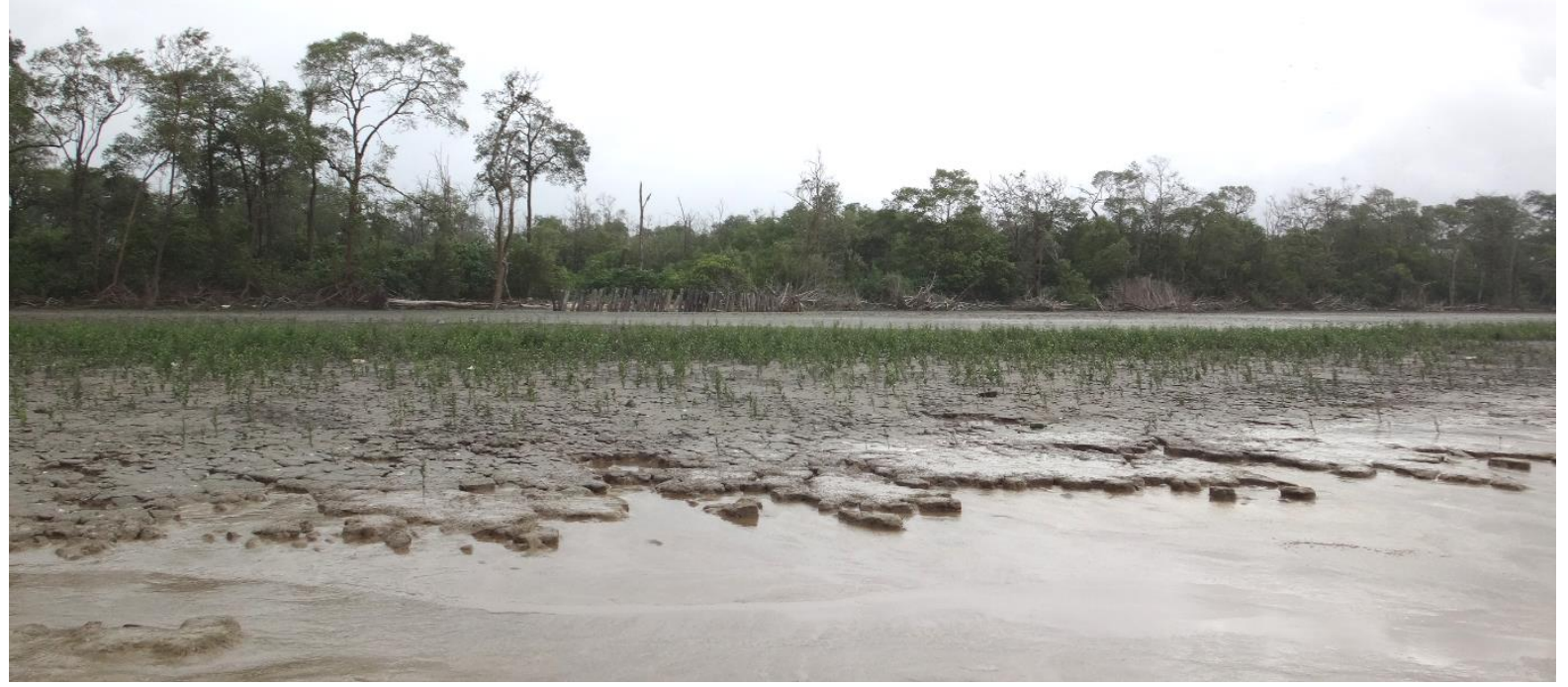

Figure 38 Spontaneous colonization by mangroves of a short-lived mud deposit at the highhigh-water elevation, Wanica district (Suriname, 2017). Notice the cracked surface, as well as the cliff erosion. Photo taken from a small boat, indicating that the water depth rapidly increases, too much for a stable mud deposit. (Credit: S. Naipal)

Care has to be taken that the sediment entrapment would not lead to disturbing the sediment balance at the alongshore downstream side of the entrapment unit. By trapping the sediments in a specific area, there may be shortage of sediment supply behind the unit. Furthermore, the diverted longshore currents may increase in magnitude and may cause increased erosion in front of the unit. The latter will lead to a concave profile of the tidal flat which will hinder the onshore sediment flux beyond.

\section{?.5 Research}

Many studies have been undertaken along the Guianas coast in order to understand its dynamics. The coastal erosion problems in Guyana (Delft Hydraulics 1962; Nedeco 1972) and the Surinam Transportation Study (Nedeco 1968), investigating improvement of the conditions for navigation of ocean-going vessels, triggered the need to study the physical conditions in order to design the sea defence wall and for finding solutions for optimal access to the ports in between the mud banks. The corresponding engineering study reports remain an important source of information and data for the region. Major scientific contributions were subsequently realized by Augustinus (1978), Rine (1980) and Wells and Coleman (1981). These studies have resulted in a good qualitative understanding of the processes. However, in view of management, it is necessary to be able to make quantitative predictions of the expected evolution of the coast, particularly in view of different climate change scenarios. Research in 
the $21^{\text {st }}$ century therefore has been focusing on collecting more field data, remote sensing data and on the development of numerical models for morphodynamic predictions.

\section{?.5.1 Research in French Guiana}

The French Guiana coast constitutes an ideal laboratory for studying the coastal margin as a highly active interface between intense physical processes and induced ecological changes ranging from mud bank colonization by pioneer mangroves to adult mangrove forest destruction. The coast of French Guiana may be considered the most pristine of these coasts in terms of mangroves and their conservation, since no human impact on the mangrove system has been observed, thus far.

Research in French Guiana has been conducted on mud bank morphology, hydrodynamics and sediment characteristics, with emphasis on the processes involved in bank migration and destruction, both driven by waves, but also in the consolidation of the surfaces of mud banks that is a pre-requisite for colonization by mangroves. The aim of this research, the overarching aspects of which are summarized here, has been to gain a better understanding of overall mud bank and coastal dynamics at various spatial and temporal scales, and how these interact with mangrove ecology, especially how mangroves become established, function, and are destroyed in this highly changing setting.

Although there is corpus of old and generally descriptive unpublished studies on these aspects, much of the recent research on mud banks and seafront mangroves commenced in the late 1990s using an approach combining field monitoring and remote sensing. Given the size of a typical mud bank (several $10 \mathrm{~s}$ to $100 \mathrm{~s}$ of $\mathrm{km}^{2}$ ) and the problems of accessibility in this dynamic mud setting, remote sensing, calibrated by ground truth studies, has clearly been an area where research has led to breakthroughs in understanding sediment dispersal and accumulation patterns along what is considered as the world's longest and most dynamic muddy coast.

\section{?.5.1.1 Field work}

Field studies on mud banks and mangroves involve considerable logistical difficulties, including the challenge of accessing experimental sites. In spite of these constraints, field work conducted in French Guiana has been fundamental in revealing processes of mudflat accretion and consolidation and mangrove colonization. Lefebvre et al. (2004) were the first to conduct high-resolution field topographic surveys that highlighted the marked surface variability of mud banks. Earlier, Fromard et al. (1998) identified, from field reconnaissance surveys, six stages of mangrove ecology, ranging from development through adulthood to destruction, that are strongly influenced by mud bank activity: (a) pioneer; (b) young; (c) adult; (d) mature; (e) mixed; (f) cemetery. The onshore-alongshore transport of mud by waves can create accreting intertidal mudflats of several $\mathrm{km}^{2}$ in days to weeks, with very dense mangrove development in just two to three years.

Several other studies based on field observations and measurements, complemented by Lidar data and satellite images have further highlighted the topographic variations over the surfaces of mud banks (Gratiot et al. 2007; Anthony et al. 2008; Gensac et al. 2015). In the leading edge of a mud bank, accreted bars form a dynamic 'suture' zone with the muddy (or 
locally sandy) intertidal terrestrial shoreline (Anthony et al. 2008, Gardel et al. 2011). These characteristic features of the low-energy inner leading part of banks form the precursor substrate conditions for mangrove colonisation. Bars in the upper intertidal zone can become immobilized over fairly long periods of low wave energy, and, thus, progressively dry out via evaporation and dewatering (Fiot and Gratiot 2006; Gardel et al. 2009), leading to the development of mud cracks, typically during neap tides, that provide opportunities for mangrove colonization (Proisy et al.2 009). Wetting and drying cycles have been shown to vary considerably with elevation (Fiot and Gratiot 2006), while field studies have shown that very subtle elevation changes in the upper intertidal zone (order of a few centimetres) can have a strong influence on successful mangrove colonization (Anthony et al. 2008; Gardel et al. 2009; Proisy et al. 2009; Gensac et al. 2011). These studies have shown that mangrove colonization can be successfully predicted based on the definition of the geographic limits of a carefully determined elevation threshold of $2.45 \mathrm{~m}$ above the local datum (Fiot and Gratiot 2006; Proisy et al. 2009; Gardel et al. 2009; Gensac et al. 2011). Above this threshold, the duration of tidal emersion is sufficient to allow for mangrove propagules to take a hold on the mud bank surface. The progressive development of mud cracks, and the corresponding colonization by pioneer and then young mangroves, over a period of several months has been monitored by an innovative system of in situ time-lapse photography aimed at highlighting changes in the surface properties of a mud bank (Gardel et al. 2009). Under favourable conditions, mangrove colonization can be extremely rapid, with plant densities exceeding 30 per $\mathrm{m}^{2}$. Rates of mangrove colonization vary considerably, however, as a function of available intertidal area. Following colonization, extremely rapid mangrove growth (individual plants grow by up to $2 \mathrm{~m}$ /year) leads to the establishment of a dense fringe of young mangroves and mud stabilization. Mangroves at all stages of establishment, from young pioneers to mature forests, can however, be destroyed by mud reworking by high-energy waves, sometimes simply through burial and asphyxia of mangrove pneumatophores (Fromard et al. 1998, 2004). In some cases (i.e. Marais Sarcelle, Sinnamary) mangrove trees (Avicennia) can die over large areas due to hypersalinization when mangrove is cut off from the sea (formation of a new chenier in front of mangrove forest), as reported above for Suriname. The ensuing mangrove pattern may, therefore, be one of coexistence of young opportunistic rapid-growth juveniles adapted to the new substrate topography and dying and dead mangroves (cemetery stage) that are asphyxiated as mud accretion occurs. The coexistence of dead, dying, and thriving pioneer and young mangroves thus reflects active mangrove renewal that is also unique feature of the mangroves of the Guianas coast.

Sedimentation rates associated with wave reworking of mud have been monitored in the field (Gratiot et al. 2007; Gensac et al. 2015). The latter study carefully documented processes of wave overwash over mud bars in the course of the rising tide. A schematic representation of the sediment dynamics on an intertidal mudflat is proposed by authors (Figure 39). Mud cracking plays a determining role in the rapid and extensive colonization, by pioneer mangroves, of a mud bank undergoing consolidation (Fiot and Gratiot 2006; Gardel et al. 2009). Gratiot and Anthony (2016) have recently shown from experimental work conducted in French Guiana that flocculation and differential settling enhance sedimentation during slack water and under low wave conditions. It can be deduced from this that enhanced settling in the leading edges of banks during such conditions is important in the temporary sedimentation that generates under-consolidated mud bars and gel-like fluid mud patches. These characteristic features of the low-energy inner leading part of banks form the precursor substrate conditions 
for mangrove colonization. Flocculation, hindered settling and settling by mass are all variably favoured by mangroves. In the trailing edge, old mangrove stands are uprooted and their root and trunk system favour turbulence dissipation under wave attack and the formation of mud pebbles from reworking of the bank. This reworking promotes the formation of dilute suspensions that enhance suspended concentrations. In the leading edge, young colonising mangrove stands favour wave energy dissipation, the formation of fluid mud patches, and settling by mass.

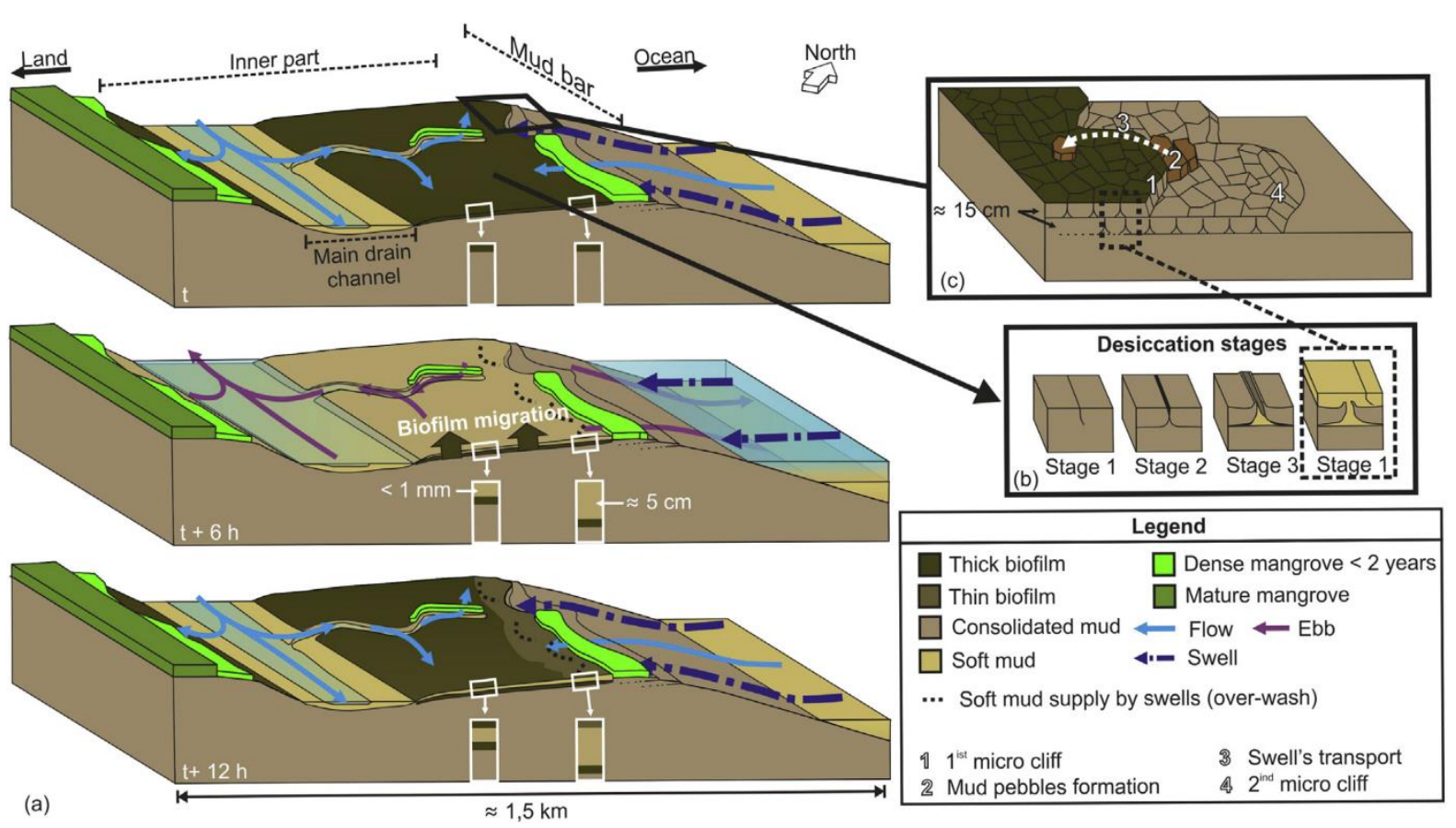

Figure 39 Schematic representation of the sediment dynamics on an intertidal mudflat in French Guiana during a tidal cycle (a). Desiccation (b) and erosion (c) of the consolidated mudflat are also illustrated. The time scales involved in the desiccation (b) and erosion (c) stages are longer than those in (a). (Gensac et al. 2015)

\section{?.5.1.2 Remote sensing}

\subsubsection{Mud bank migration and SPM dynamics in coastal waters}

Following the example of earlier work in Suriname (Augustinus 1978), Froidefond et al. (1988) used aerial photographs acquired during the late 1970s and 1980s to determine rates of mud bank migration. A mean velocity of mud bank migration of one $\mathrm{km}$ a year was determined from the interpretation of these aerial photographs.

The advent of moderate-to-high resolution satellite images (LANDSAT TM, SPOT) in the 1990s offered a new opportunity for the monitoring of the highly dynamic coast of French Guiana. Several studies have explored the capacity of these new sensors, initially to quantify mud bank migration (Froidefond et al. 2002, 2004; Baghdadi et al. 2004; Gardel and Gratiot 2005; Gratiot et al. 2007), and, more recently, suspended particulate matter in coastal waters and in mangrove dynamics (Vantrepotte et al. 2013; Gensac et al. 2016). Froidefond et al. (2002) characterized the spectral remote sensing reflectance of coastal waters. Later, Froidefond et al. (2004) established a correspondence function between in situ optical data and 
concentrations of suspended particulate matter obtained from coastal surveys. This function was then applied to a set of SPOT satellite images to estimate suspended particulate matter concentrations near the sea surface at different dates.

Radar (ERS and RADARSAT) and optical (ASTER) satellite images collected from 1997 to 2001 have been used to evaluate the capacity of these types of sensors in detecting mud banks and in monitoring coastline change (Baghdadi et al. 2004). This work showed that lowangle radar is more efficient in detecting mud banks, whereas high-angle radar is more appropriate for monitoring coastline change. These results also showed that, depending on the water level on the mud bank, optical or radar satellite images were more or less accurate.

Gardel and Gratiot (2005) attempted to extract rates of mud bank migration by applying image-analysis algorithms on SPOT images covering the period 1986-2003. They showed that rates of migration have been significantly more important over the last decade (up to $2 \mathrm{~km} /$ year) covered by these images, possibly as a result of enhanced wind-wave activity, as suggested by wave models of the Atlantic. Gratiot et al. (2007) highlighted an increase in wave forcing over a 44-yr period (1960-2004) related to an increase in trade-wind velocities.

In more recent works using remote sensing methods of sea colour comparison of SPOT images and MODIS suspended particulate matter (SPM) maps between 2002 and 2010, Vantrepotte et al. (2013) revealed the strong spatio-temporal coupling between SPM and the dynamics of local mud banks. This study suggested that the highest MODIS SPM values (>13 $\mathrm{g} / \mathrm{m}^{3}$ approximately) can be significantly associated with the subtidal part of the banks as well as to the related turbid plume (Figure 40). Mud bank migration rates derived from MODIS SPM data are, on average, higher than $2 \mathrm{~km} /$ year, in agreement with previous studies.
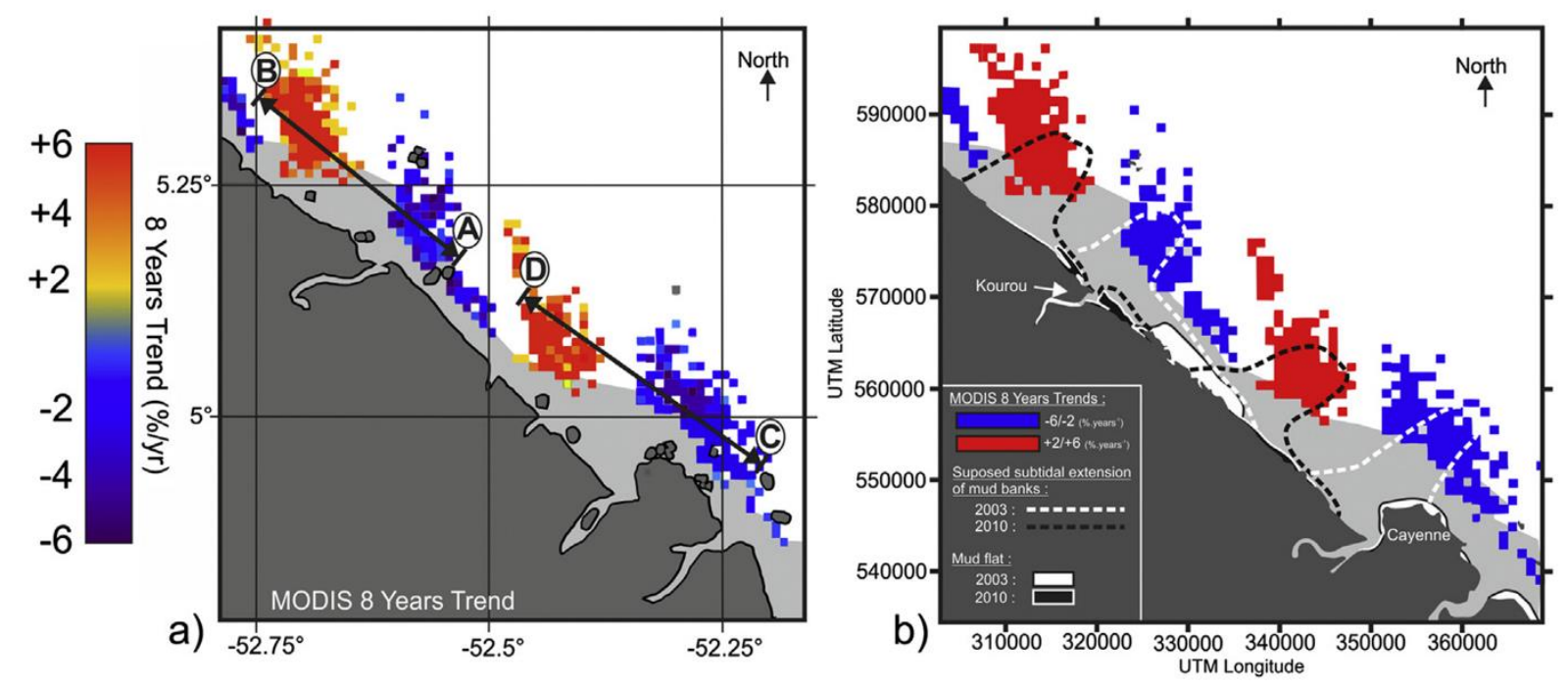

Figure 40 Significant trends in SPM detected over the French Guiana coast from the 8 year MODIS time series (a) (in \% year ${ }^{-1}$ ) and comparison with the mud banks estimated position and morphology (b). SPOT estimates of the location of the mud flat and subtidal extension of the mud bank at the beginning and end of the MODIS time series considered are represented by white and dark grey surfaces and dashed lines, respectively. The subtidal mud bank extension has been determined from swell damping characteristics (SPOT images). (Vantrepotte et al. 2013) 
Gensac et al. (2016) used MODIS satellite data over the period 2000-2013 to assess the sediment dynamics in the shallow coastal waters from the Amazon River mouth to the Capes region (northern part of the Amapa region of Brazil and eastern part of French Guiana). They determined the role of continental and oceanic forcing and the implications for coastal geomorphology and mud bank formation. This work also confirmed an average rate of mud bank migration of up to $2 \mathrm{~km} /$ year.

\subsubsection{Decadal-scale mud bank dynamics and mangroves}

The dynamics of mangroves on the Guianas coast are extremely variable as their spatial and temporal extension and stages of development are determined essentially by the waxing and waning of mud banks. In this system, mangroves play an important role by stabilizing the muddy substrate and ensuring plant 'continuity' with the older muddy shoreline, from which mangrove regeneration is best assured by propagule dispersal. Each erosive inter-bank phase can result in the partial, or rarely, total erosion of a previously welded bank. Such total erosion can occur during a subsequent inter-bank phase characterised by particularly high wave-energy seasons such as El Niño years or phasing of the NAO. Gardel and Gratiot (2006) showed, however, that such waves do not necessarily always have a destructive impact on mangroves. Their analysis of shoreline changes in French Guiana over the period 1995-2000, characterized by high wave energy, showed that mangroves in inter-bank areas underwent very active retreat (150 to $200 \mathrm{~m} / \mathrm{year}$ ), but at the same time the mud bank areas experienced mangrove colonization. Gratiot et al. (2007) also showed that notable phases of increased wave energy tended to be accompanied by higher annual rates of alongshore mud bank migration. Fromard et al. (2004) proposed a global scenario of mangrove forest dynamics, including a model of forest development, forest gap processes and sedimentological dynamics.

Gratiot et al. (2008) calculated a mass mud bank budget along the French Guiana coast from 1988-2004 based on satellite images, and suggested a link between budget fluctuations and the 18.6-year nodal tidal cycle, which they considered as an important factor in modulating coastal erosion and accretion in the Guianas. A detailed 64-year inventory (1950-2014) of mangroves and their multi-decadal area variations as a function of the spatial extent of mud bank and interbank zones on the French Guiana was conducted by Walcker et al. (2015). This inventory showed that the area covered by mangroves fluctuates significantly at this multi-decadal timescale depending on the global domination of bank or inter-bank phases at any time. The mangrove cover in French Guiana in 2014, for instance, has been estimated at 45,000 ha by Walcker et al. (2015). The authors showed that fluctuations in mangrove area were not due to current sea-level rise nor to the 18.6-year nodal tidal cycle identified by Gratiot et al. (2008) but to the pervasive role of NAO-driven multi-decadal fluctuations in wave energy (Figure 41). Proisy et al. (2016) proposed a model of the French Guiana coastal system where interaction functions between ecological and physical processes are written to specify how ocean/mangrove shoreline/mud bank change when they interact. This approach has been

applied to study mangrove shoreline variations from 1986 to 2009. A time series of remote sensing images was used during the initialization and validation phases. 


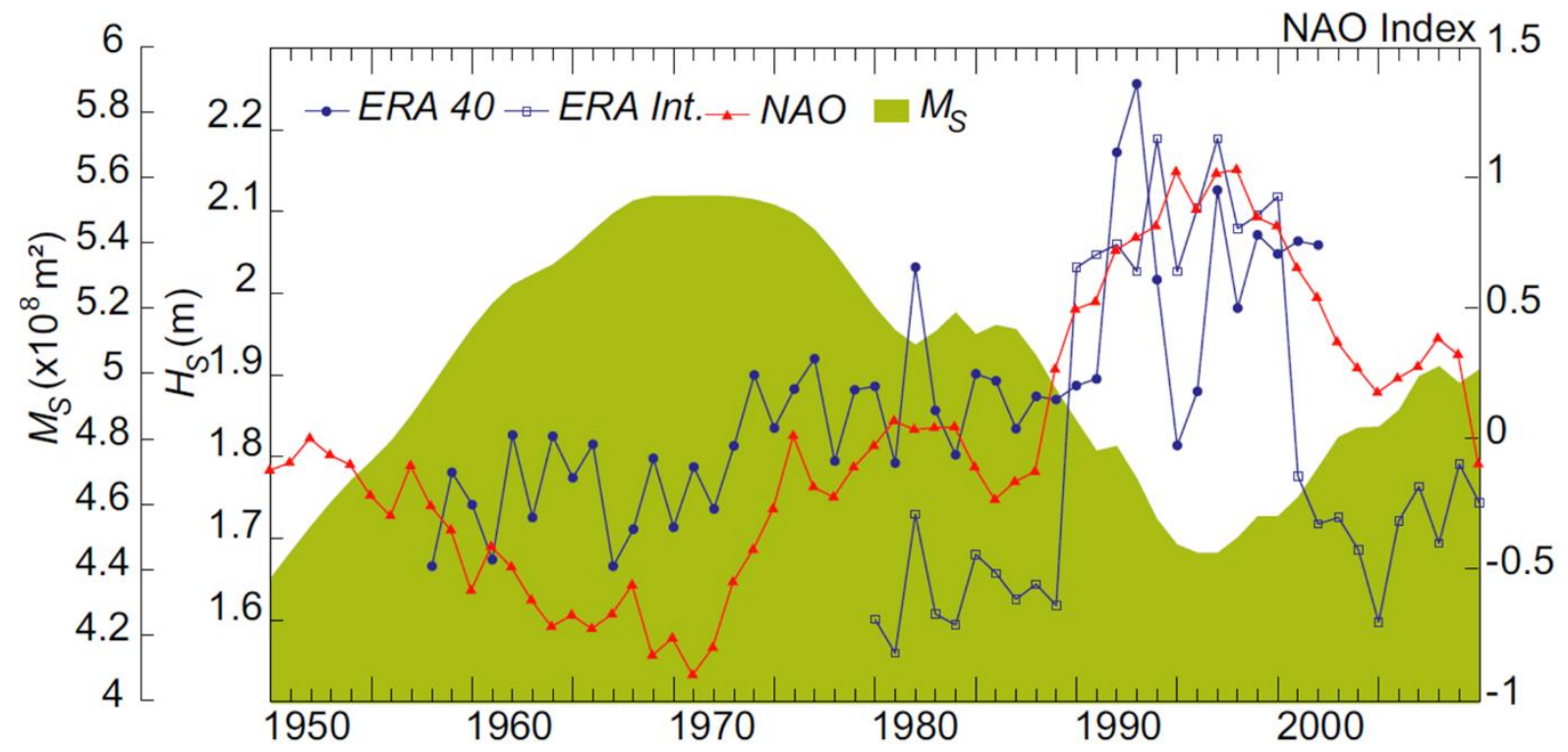

Figure 41 Relationship between the mangrove surface area (MS) and significant wave heights (HS), and their link with the North Atlantic Oscillation (NAO). The ERA-40 product was used to assess the winter HS from 1958 to 2002, whereas the ERA-Interim product was used for the period of 1980-2010. The 10-year moving average of the NAO winter index is also plotted on the graph; it exhibits a significant temporal correlation with MS and HS. (Walcker et al. 2015)

All of the foregoing studies have been significant in understanding the development, morphology and sediment dynamics of the coast and their relationship with mangrove ecology. Much still remains to be done, however, regarding these aspects. Areas for forthcoming research concern changing rates of mud bank migration, how these rates will be affected by climate change, and the corresponding impacts on mangroves.

\subsection{Coastal engineering research in Suriname}

The first important engineering study for the Suriname coast was performed by the Dutch engineering consultants group Nedeco (1968) in the framework of improving the navigation access to the ports. In-depth geomorphological research in Suriname has then been pioneered by Prof. Augustinus from the University of Utrecht (the Netherlands). Despite efforts, Suriname remained dependent for a long time on external expertise with regard to coastal engineering. This changed early $21^{\text {st }}$ century when the Anton de Kom University of Suriname (AdeKUS) in Paramaribo appointed Surinamese scientists with the proper background, who studied abroad, as academic staff.

Within the framework of interuniversity development cooperation, funded by the Flemish Interuniversity Council (VLIR-UOS), the Hydraulics Division of the University of Leuven (KU Leuven, Belgium) has first established laboratory facilities for hydraulic engineering research. Subsequently, they ran a so-called "own initiative" project (2005-2010) to establish the necessary research capacity at the AdeKUS to study the coastal processes in more detail by carrying out field campaigns (www.kuleuven.be/hydr/SurinamCoast/SurinamCoast.htm).

The Hydraulics Laboratory, Department of Infrastructure, of AdeKUS now disposes of a small sea-borne motorboat equipped with a (by software) coupled system of GPS, dual- 
frequency echo-sounder and acoustic Doppler current profiler (ADCP) for transect monitoring of bathymetry, fluid mud layer thickness, velocity profiles and turbulence. Furthermore equipment is available for frame deployment to collect time series data on sediment concentrations with optical backscatter (OBS) probes, flow velocity, turbulence and water depth with acoustic Doppler velocity meters (ADV) and the same ADCP can also be used bottom-mounted, upside down to measure velocity profiles and directional waves. This should allow local data collection and research to support the proposed sustainable management of the coastal zone.

A major goal of the research is the set-up of a complete morphodynamic model for the Guianas coast where all the physical processes, described above, are incorporated and local data used. This model is discussed in more detail in the following section.

\section{?5.3 Research in Guyana}

Coastal research in Guyana is scarce and generally little known. Nevertheless, the continuous threats to the western part of the Guianas coast invited several geological studies (Nota 1958; Hawkes 1962; Morelock 1972; Daniel 1989; Lakhan et al. 1998, 2002 and 2006). Important engineering studies related to the design of the coastal defence system have been carried out by Delft Hydraulics (1962) and Nedeco (1972). The "Institutional Capacity Building Activities on Guyana Sea Defences" project (2004-2005), carried out by the Dutch consortium of Delft Hydraulics and Royal Haskoning, constitutes the most prominent research for the Guyana coast, reviewing existing knowledge and including the gathering of much new field data (Les and Westra 2004; Westra 2004) and the development of a powerful modelling tool (de Graaff et al. 2005a, 2005b; Winterwerp et al. 2005b), briefly discussed in the next section.

\section{?.5.4 Morphodynamic modelling of the Guianas Coast}

Even though different studies have been looking at the actual time scales for the recent evolution of the Guianas coastline, there is no consensus. The main reason is that dedicated observations have only started around the " 40 s of the twentieth century, which constitutes a period of about 80 years of information which is too short relative to the estimated cycle of roughly 30 years for the passing of a mud bank. Looking at the sequence of all the mud banks over the entire $1000 \mathrm{~km}$ stretch of the Guianas coastline may give an impression of how the mud banks evolve during their migration from east to west, which takes them about 500 years. However, the effects of climate change and sea level rise may make the interpretation back in time uncertain. Moreover, the coast has been under increasing anthropogenic pressure during the last decades, and it becomes increasingly difficult to distinguish natural from anthropogenic effects.

Furthermore, it is dangerous to extrapolate the future based on the past, certainly in view of the large uncertainty on sea level rise (certainly for South America, where little SLR data are available). There have been various studies on how a mangrove coast responds to sea level rise (Alongi 2008; McIvor et al. 2013). Based on the study of the evolution of the Guianas coast over the Holocene period (Rine 1980; Rine and Ginsburg 1985), there is some evidence that a healthy and wide enough mangrove belt along may be resilient enough and may follow sea 
level rise, provided there is enough sediment supply. This may explain why the Guianas mangrove coast is not considered vulnerable by IPCC (Alongi 2008; Wong et al. 2014). Much depends on how the sediment supply from the Amazon basin will evolve and respond to climate change. Nevertheless, the local authorities have worries because of the reality of increasing flood events in vulnerable spots. Numerical models can be used to assess the impact for different scenarios. Such a model would then serve as a decision support tool to study potential threats to the coastline. This model should allow to answer (a.o.) the question if the coastline will be able to follow sea level rise by sediment accumulation, depending on the expected evolution of sediment supply from the Amazon. The latest data analysis indeed indicates that the sediment supply is increasing (see section ?.2).

These are some reasons why numerical models for the study of morphodynamic processes are believed to be a very useful tool. These models simulate the movement of water and sediments over periods of months to decades, depending on the specific research question, by solving the conservation equations of mass and momentum for water and the sediments. Several modelling initiatives have been undertaken over the past decade and will briefly be presented in the following sections.

\section{?.5.4.1 French Guiana coast model}

A 3D numerical model of the French Guiana coast was built by Chevalier et al. (2004) and further developed by Bourret et al. (2005, 2008). The model covers most of the French Guiana coastline until the $100 \mathrm{~m}$ isobath line (Figure 42a). This finite difference model was built to analyse the influences of river discharges and wind on the offshore current, salinity and temperature distribution. Special attention was paid to the treatment of the offshore boundary condition (passive or active boundary).
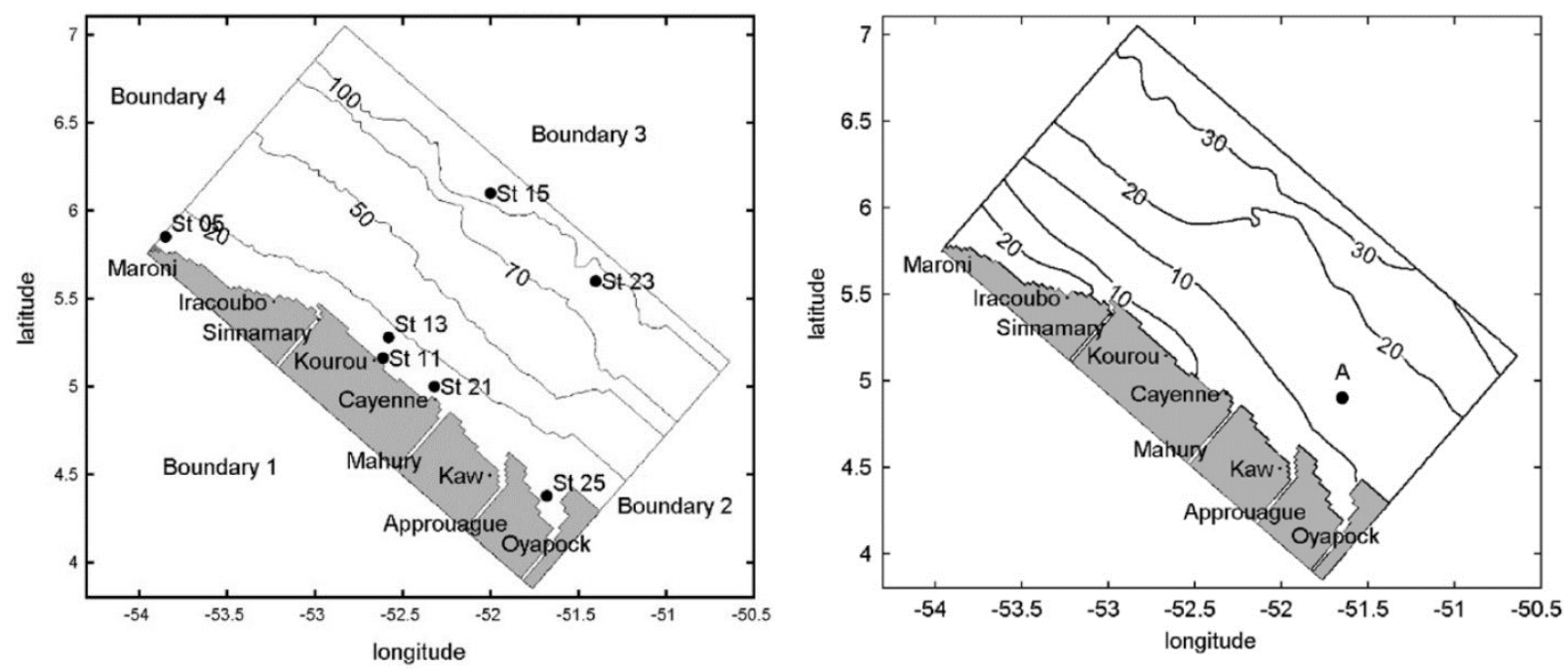

Figure 42 Numerical model of the French Guiana coast: (left) model domain and bathymetry, and (right) modelled field of sea surface salinity (Bourret et al. 2008).

Numerical results (Bourret et al. 2008) point out the tidal currents are about $0.15-0.45 \mathrm{~m} / \mathrm{s}$ on the inner shelf along the neap-spring cycle. They reach $0.55 \mathrm{~m} / \mathrm{s}$ near Sinnamary and near the mouth of Oyapock river. Offshore tidal currents are weaker, $0.05-0.1 \mathrm{~m} / \mathrm{s}$, and the currents are 
then dominated by the oceanic circulation. The Guiana current can reach $1.1 \mathrm{~m} / \mathrm{s}$ offshore and $0.3 \mathrm{~m} / \mathrm{s}$ at $30 \mathrm{~m}$ depth. The surface salinity field (Bourret et al. 2008) describes a weak salinity tongue linked to two influences. The first one in the area between 10 and 20 psu (Figure 42b) may be attributed to the Amazon influence. The second one in the area lower than 10 psu near the coast is due to the local river discharges.

A smaller 3D model (Figure 43) was also built by Chevalier et al. (2008) to analyse the combined effect of the current and wave on the mud transport around mud bank. This model extends $60 \mathrm{~km}$ length alongshore and up to $25 \mathrm{~m}$ depth. Between $20 \mathrm{~m}$ depth and the coastline, the bathymetry is continuously changing due to banks mobility. As no regular survey of the bathymetry is performed, Chevalier et al. (2008) rather propose to work with an idealized bathymetry (Figure 44).

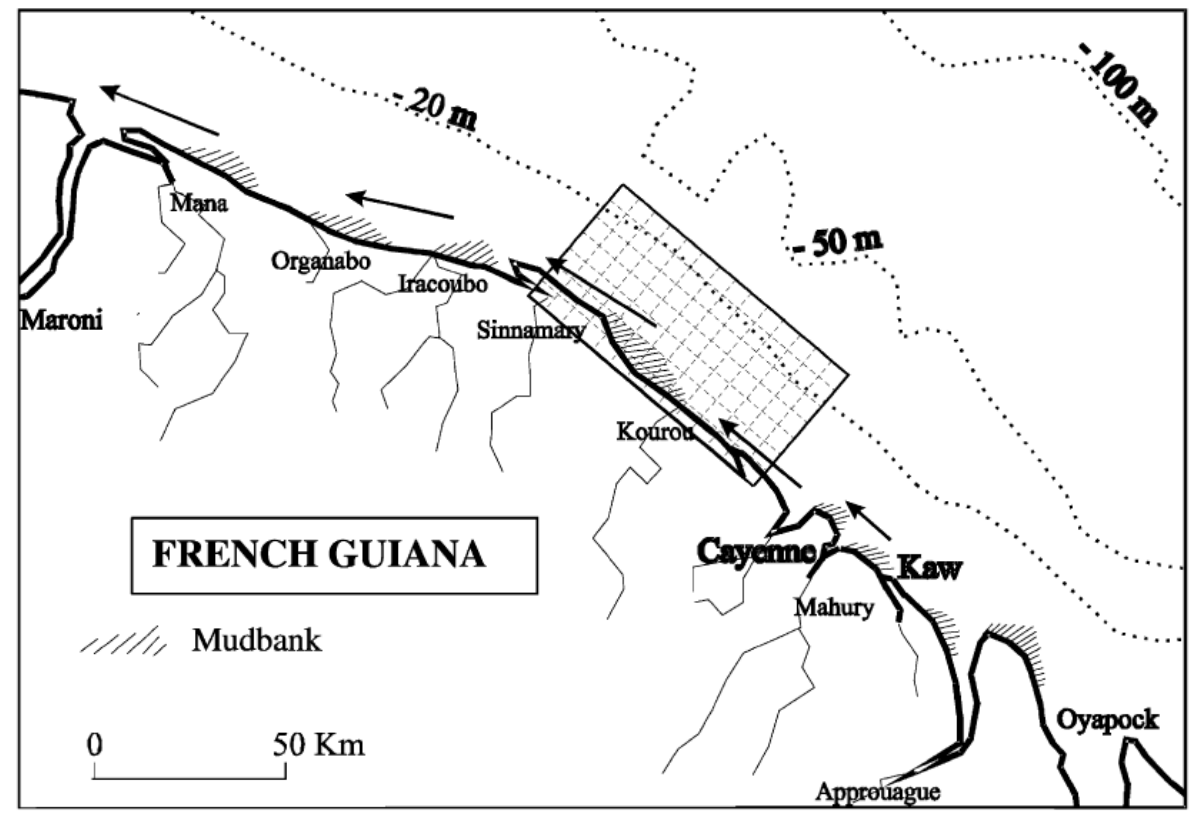

Figure 43 Situation of the mud bank model of Chevalier et al. (2008)
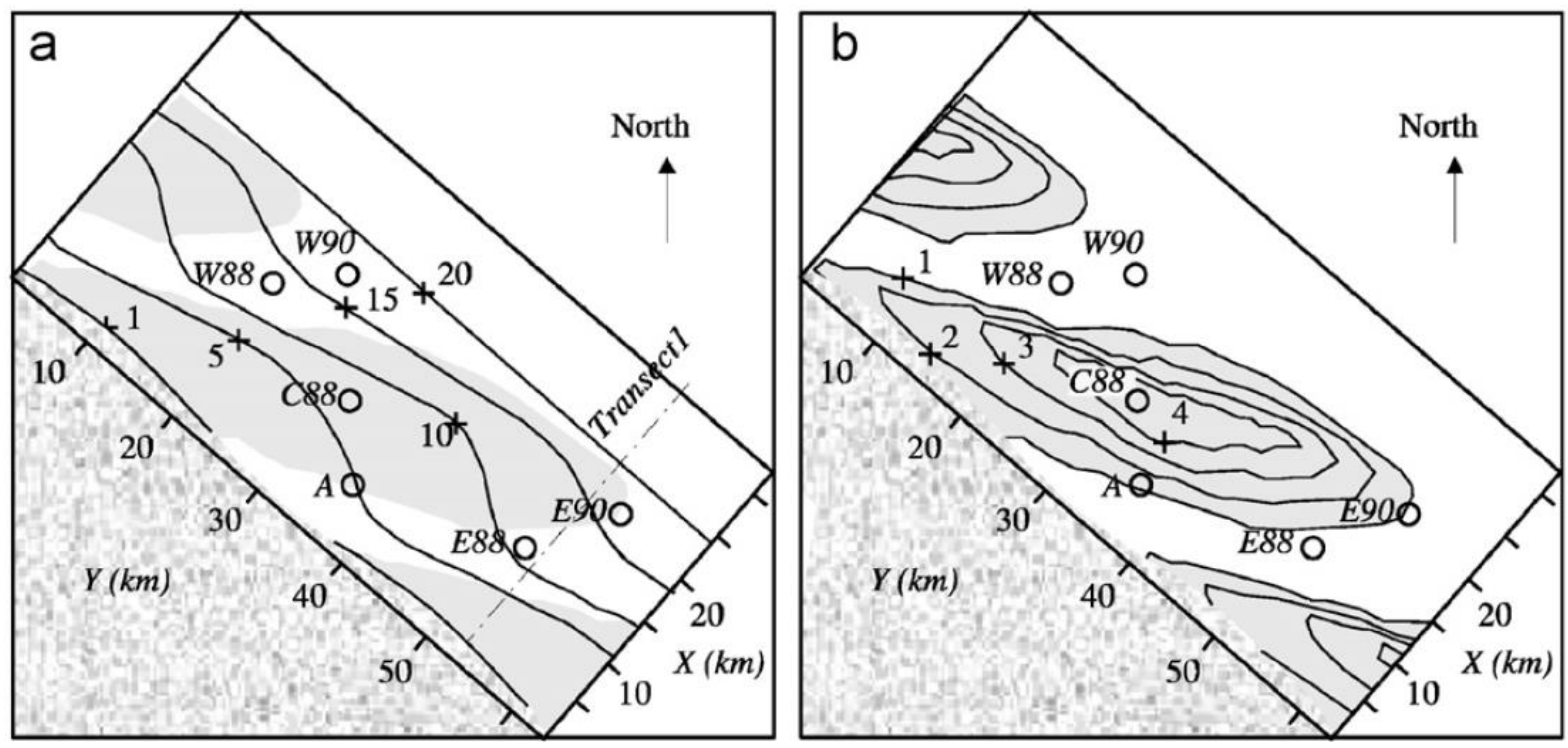

Figure 44 Mud bank model: a) idealized bathymetry; b) mud layer thickness contours (Chevalier et al. 2008) 
For this study, only hydrodynamics and suspended sediment concentrations were calculated. The influence of salinity and temperature have been neglected. Waves are modelled using Fudaa-Vag (CEREMA 2011) and the wave damping is integrated through the model of Rodriguez and Mehta (2000).

The models (Chevalier et al. 2004 and 2008, Bourret et al. 2005 and 2008) allow to give general insight on the influence of the different forcing. However, full validation of these models were not feasible because of the lack of physical in situ data.

\section{?.5.4.2 Mahury Estuary (French Guiana) model}

A 3D numerical model of the Mahury Estuary (Figure 45) has been built in the framework of research on the accessibility of the port of Cayenne during a period of passage of a mud bank over the approach channel (Orseau 2016). The model is built with the TELEMAC software (www.opentelemac.org). The work here focusses more on the estuarine dynamic. In situ data sets collected by Orseau (2016) are exploited to perform calibration and validation of the model. The model extends $20 \mathrm{~km}$ alongshore $20 \mathrm{~km}$ offshore and $40 \mathrm{~km}$ inland. The extension has been chosen according to the annual bathymetric surveys occurring around the navigation channel. The horizontal mesh (Figure 45b) comprises about 21000 nodes. Simulations are run for 6 months with 8 vertical layers. For the turbulence, a mixing length model is selected with damping function to account for stratification.

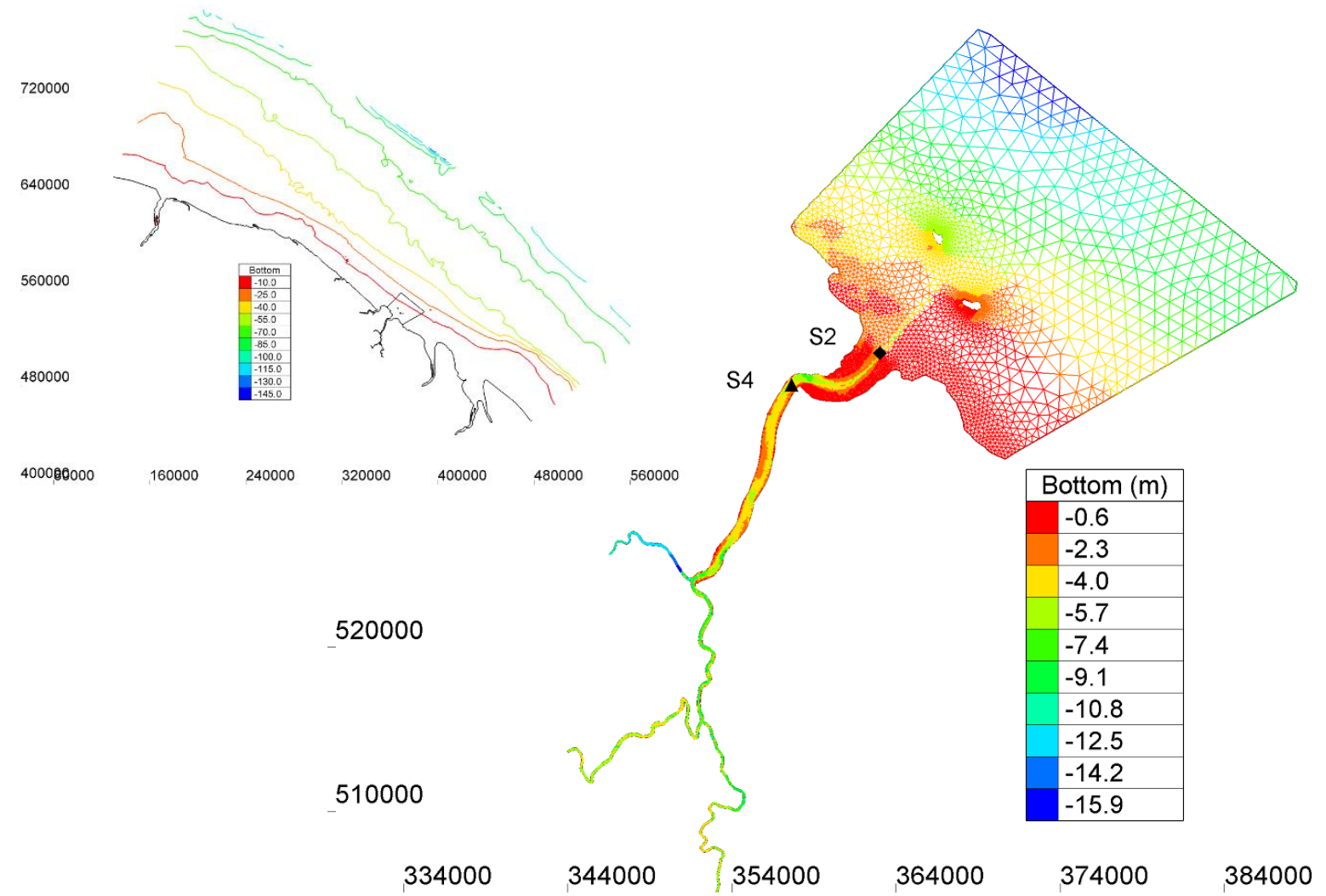

Figure 45 Numerical model of the Mahury Estuary: (left) situation and model extend, (right) the horizontal mesh. (Credit: S. Orseau, ULCO/CNRS/CEREMA)

Up to now, only the 3D hydrodynamic model has been validated in regards of salinity and current. Figure 46 illustrates comparison of the modelled salinity with measurement (Orseau 
2016) at the bottom on station S2 and S4 during a neap-spring cycle in the wet season. The 3D sediment transport model is still under development. In addition, it is also foreseen to build a larger scale model covering the whole French Guiana coastline which includes the Maroni and Oyapock estuaries. This model would serve to study the Maroni dynamics and to provide offshore boundary conditions to local estuarine model in term of salinity and SPM plume or wave forcing.

552000

S1

540000

528000

S5 Auberge

S6 Stoupan

516000
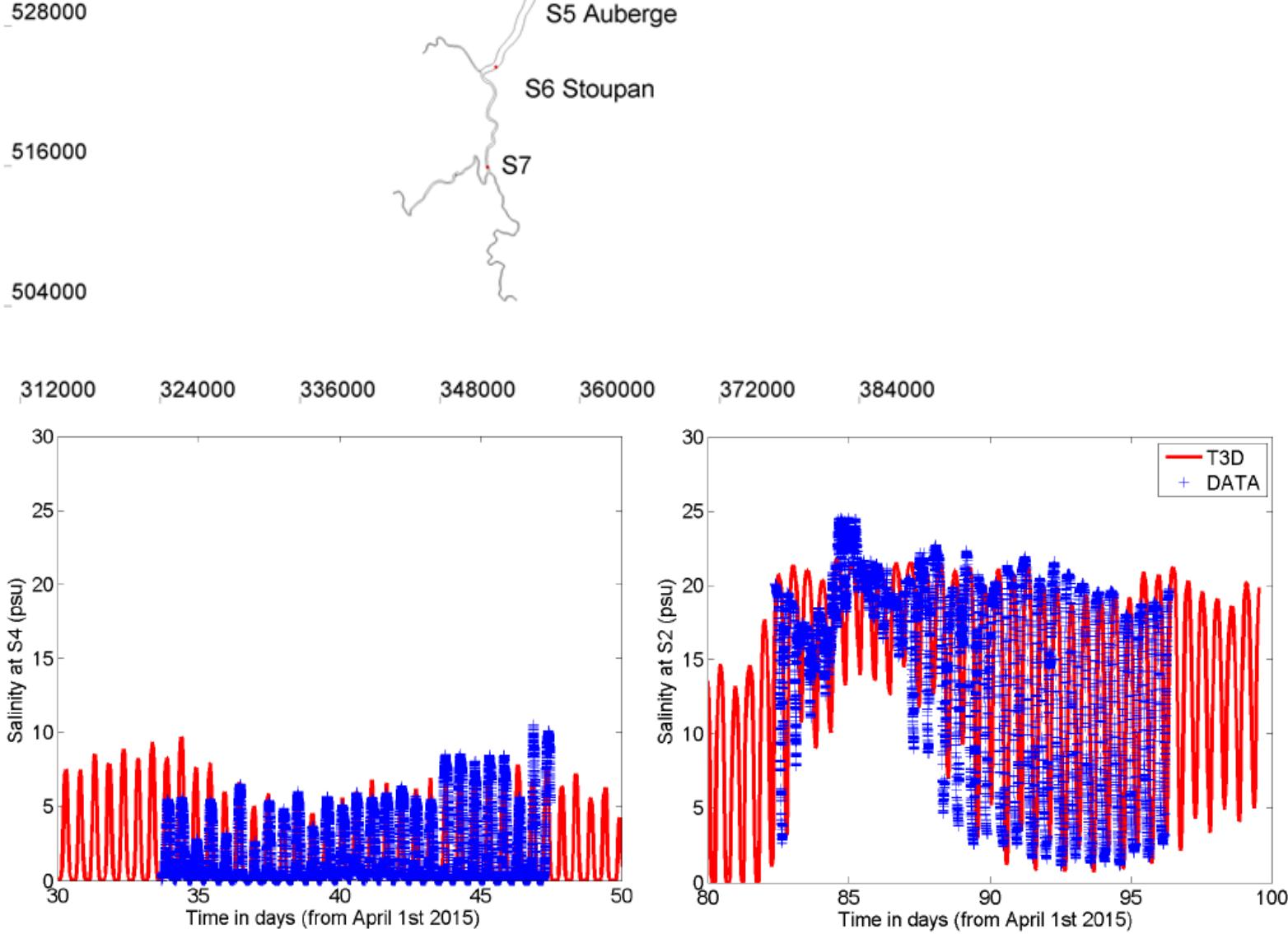

Figure 46 Location of the measuring stations (top). Time evolution of the salinity at the bottom: (left) at station S4 near the only harbour of French Guiana (left) and at the mouth (right). (Credit: S. Orseau, ULCO/CNRS/CEREMA)

\section{?.5.4.3 Suriname coast model}

The KU Leuven morphodynamic model for the Suriname coast has been under development since 2005 with the help of several MSc thesis projects (Gyssels and Van der Zype 2006; Dewaelheyns and Etneo 2007; Dirkx and Fockedey 2008; Hermans and Kroeders 2012; Pelckmans 2014) and an internship (Wongsoredjo 2017). The model is based on the open 
source TELEMAC software (www.opentelemac.org), using the hydrodynamic module TELEMAC (Hervouet 2007), the spectral wave module TOMAWAC (Benoit et al. 1996) and the sediment transport module SISYPHE. Several modifications to the code are developed and tested.
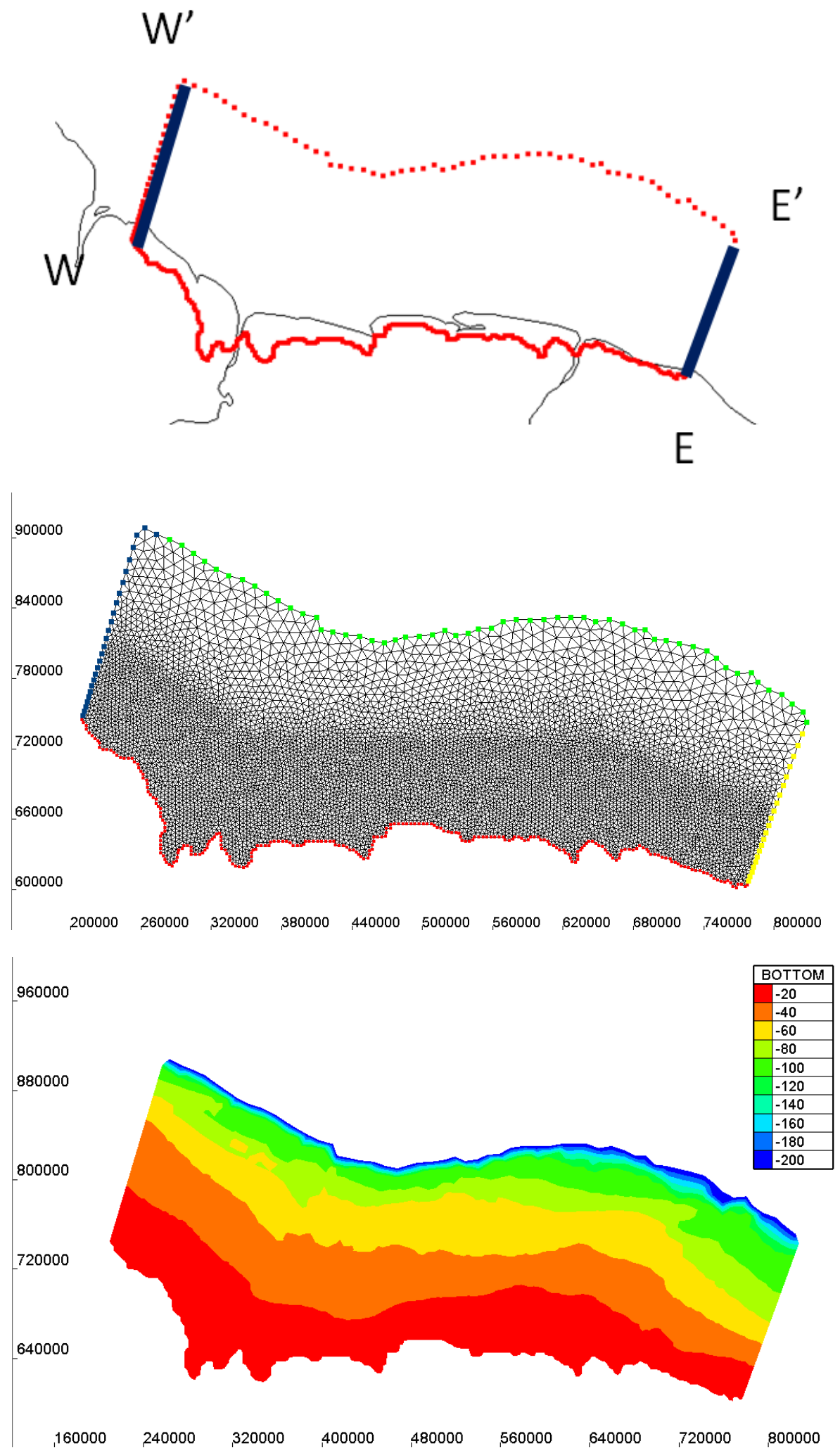

Figure 47 Suriname coast model: domain boundaries, relative to the actual coastline (top); numerical model mesh (middle) and bathymetry (bottom). (Credit: Hydraulics Division, KU Leuven) 
The model domain (Figure 47) comprises the entire Suriname coast, from the Maroni river in the east, which is the border with French Guiana, to the Corentyne river in the west, which is the border with Guyana, and a part of each neighbour's coastline. The land boundary has been taken more inland, allowing to simulate inundation of the mangrove forests. The northern boundary is taken along the edge of the continental shelf.

Mud banks have been given different erosion properties than the interbank areas, since the former consist of soft mud, which is much more erodible than the overconsolidated mud layer exposed in the interbank areas. For this purpose, the mud banks had to be identified, which was done based on comparison of bathymetric data with satellite images (Figure 48).
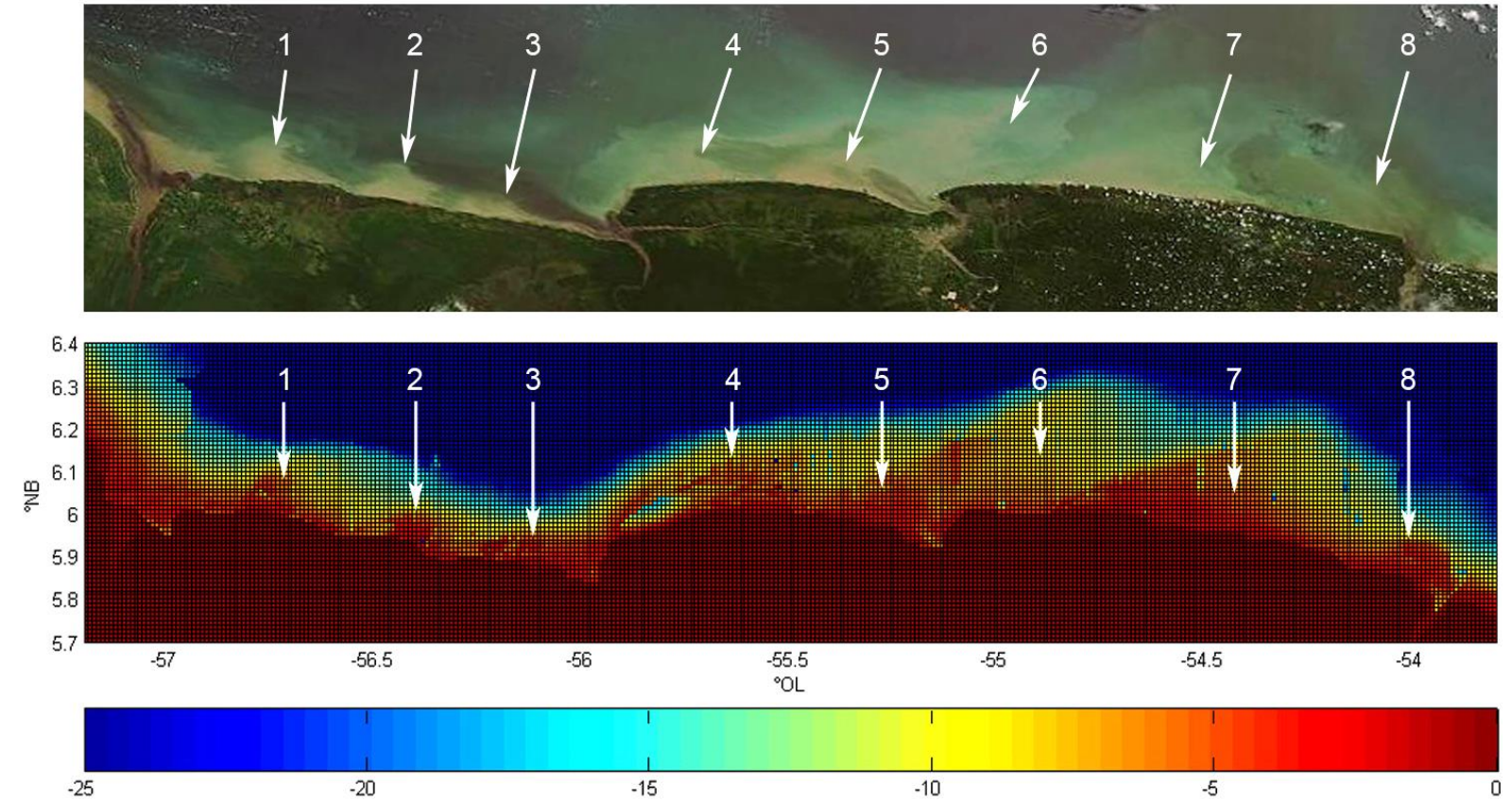

Figure 48 Upper image: MERIS satellite image of 1 August 2006 in visible spectrum (ESA Earth Online), lower image: bathymetry along the coast of Suriname in 2005 (Dewaelhyens and Etneo 2007).

Like for the other models, by lack of sufficient in-situ data for calibration and validation, only qualitative results have been obtained thus far. Future efforts will be dedicated to including wave damping by the mud banks. Subsequently, the model can be used for scenario studies to include sea level rise and subsequent inundation of the mangroves (cf. Lovelock et al. 2015). The mangrove field can be given a higher resistance by modification of the friction coefficients for currents and waves (Escobar Ramos 2017). The latter can be developed more accurately based on the recent work of Maza et al. (2015) where wave damping by regularly and arbitrarily distributed stems has been simulated in detail at the scale of laboratory flume studies.

\section{?5.4.4 Guyana coast model}

In the framework of the Institutional Capacity Building Activities on Guyana Sea Defences project, carried out by the Dutch engineering consultants WL Delft Hydraulics (now Deltares) and Royal Haskoning, developed a modelling framework to study 3D currents, waves and morphodynamics along the Guyana coast (de Graaff et al. 2005a, 2005b; Winterwerp et al. 
2005b) with the software Delft3D and SWAN (Booij et al. 1999). For this purpose the SWAN model was extended to allow simulation of wave damping by fluid mud (Kranenburg et al. 2011). Necessary data have been collected during various campaigns (Les and Westra 2004; Westra 2004). The model was aimed as research tools and as assessment tool for defining operational and extreme hydraulic conditions for the design of sea defence structures. Application of the model (Figure 49) has demonstrated that wave damping has to be accounted for in order to simulate observed conditions (Winterwerp et al. 2006). The model has subsequently been used to study the coastal evolution of the Guyana coast since 1950 (Welage 2005).

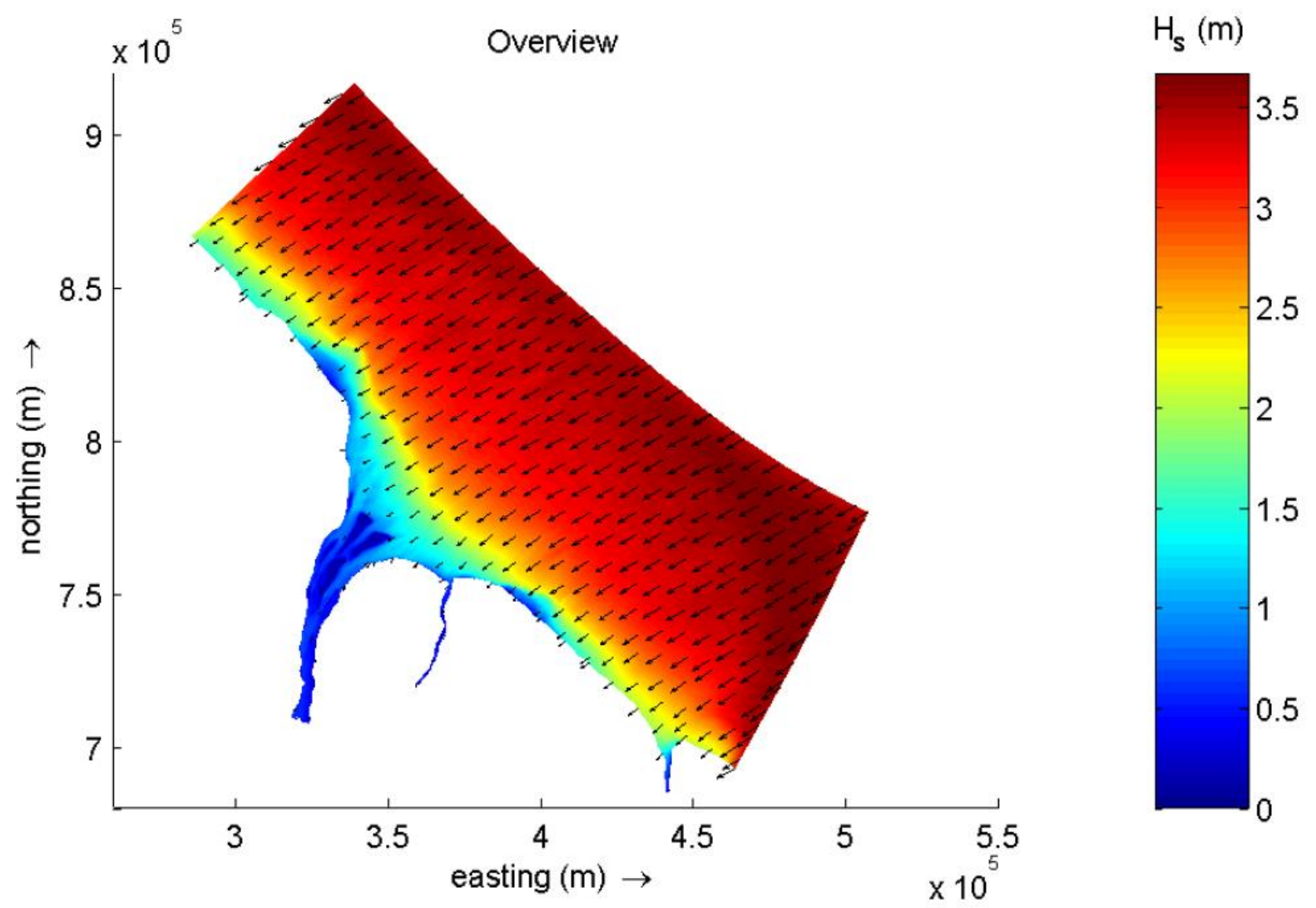

Figure 49 Modelled significant wave heights $(\mathrm{m})$ in the detailed Delft3D Guyana model for a return period of 1 year and the dominant north-eastern wind and wave direction of $60^{\circ}$, including wave damping by fluid mud (de Graaff et al. 2005b).

\section{?.6 Conclusions and Perspectives}

The potential of mangroves to protect coastal areas is very site specific. In many studies only the interaction between vegetation and hydrodynamics is considered, forgetting that the local sediment dynamics should be taken into account in order to understand how the natural system works.

In the case of the Guianas coast, the interaction between these three key players: mangroves, hydrodynamics and sediment dynamics, is now quite well understood. The mangroves require (relatively) quiet hydrodynamic conditions in order to capture and stabilize sediments. This shelter is provided when a mud bank shields the mangroves from direct wave action. During interbank periods (when there is no protecting mud bank in front of the mangroves), the 
mangroves are slowly destabilized by wave action and washed away, and the coast erodes; i.e. on their own mangroves do not provide sustainable protection. In the Guianas there is an alternation of mud bank and interbank periods, a cycle of the order of 30 years. For an undisturbed mangrove belt, this results into a net accretion of the order of one meter per cycle, which is supported by geological evidence. Furthermore, there are indications that the sediment supply form the Amazon basin has been increasing significantly over the past decades, which raises hope that flood risks by potential sea level rise can be mitigated by nature itself.

The knowledge and understanding of these processes provide the necessary arguments to protect the mangrove belt as the most efficient, cost-effective and sustainable shore protection. Action needs to be taken to prevent further deterioration of the mangrove belt. Vulnerable places where the mangrove fringe has become too narrow or has been removed, are now considered for mangrove rehabilitation projects. Several pilot restoration projects are currently ongoing in Guyana and Suriname. Both mangrove rehabilitation projects do many efforts to realize community based mangrove management. They are working in the areas of administrative capacity development, monitoring and research, community development and capacity building, awareness and education.

The presented overview of recent research initiatives shows that much work still remains. Collection of field data and long-term monitoring remain too limited because of insufficient resources. Moreover, many places are difficult to access either from land or from the sea. Remote sensing plays an important role for filling up data gaps. They have already been used to analyse coastal erosion, mud bank migration and mangrove dynamics. They allow also the generation of instantaneous surface suspended sediment concentration maps for the entire coastal area (even though the conversion algorithms are still subject of research since they need improvement).

Development of numerical morphodynamic models for each of the Guianas is ongoing. Several interacting complex processes (i.e. interaction of waves with non-homogeneous fluid mud and of currents and waves with mangroves) are still difficult to be modelled correctly and require more fundamental research. Eventually, it is intended that operational models will become available to local authorities as decision support tools for coastal zone management.

Furthermore, scientific capacity building is locally realized through the international MSc program in "Sustainable Management of Natural Resources", taught in English at the Anton de Kom University of Suriname (http://vlir-iuc.uvs.edu/smnr/), established in 2007 with support of the University Development Cooperation division of the Flemish Inter-University Council (www.vliruos.be). In this program, a specialized training course on "Coastal erosion and protection" is taught in collaboration with hydrodynamic and morphodynamic experts from the Hydraulics Division of the Department of Civil Engineering from the KU Leuven (Belgium). This course provides the general theory on the interaction between hydrodynamics, morphodynamics and mangroves and is then applied specifically to the Guianas coast. Furthermore, it provides an introduction to field monitoring techniques, numerical modelling and field excursions.

The Guianas mangrove coast in many aspects is unique. Nevertheless, the ongoing research efforts and mangrove rehabilitation projects may provide important insights and lessons for other mangrove coastlines around the world. 


\section{?.7 References}

Adams R (2014) Time 0 Monitoring Lima, Region No.2. Report, NAREI, Mon Repos, Guyana. Allersma E (1968) Mud on the oceanic shelf off Guiana. Paper Cicar Symposium Curaçao, $11 \mathrm{p}$.

Allison MA (2000) Origin of Amazon mud banks along the northeastern coast of South America. Marine Geology 163:241-256.

Allison MA, Lee MT (2004) Sediment rexchange between Amazon mud banks and shorefringing mangrioves in French Guiana. Marine Geology 208:169-190.

Alongi DM (2008) Mangrove forests: resilience, protection from tsunamis, and response to global climate change. Estuarine, Coastal and Shelf Science 76(1):1-13.

Anthony EJ, Dolique F, Gardel A, Gratiot N, Proisy C, Polidori L (2008) Nearshore intertidal topography and topographic-forcing mechanisms of an Amazon-derived mud bank in French Guiana. Continental Shelf Research 28:813-822.

Anthony EJ, Gratiot N (2012). Coastal engineering and large-scale mangrove destruction in Guyana, South America: averting an environmental catastrophe in the making. Ecological Engineering 47:268-273

Augustinus PGEF (1978) The changing shoreline of Surinam (South America). PhD dissertation, Universiteit Utrecht, Uitgave No.95, Natuurwetenschappelijke Studiekring voor Suriname en de Nederlandse Antillen, Utrecht.

Augustinus PGEF (2004) The influence of the trade winds on the coastal development of the Guianas at various scale levels: a synthesis. In: F. Baltzer, M.A. Allison and F. Fromard, (eds) Material exchange between the Upper Continental Shelf and Mangrove Fringed Coasts with special reference to the N. Amazon-Guianas Coast. Marine Geology 208(SI): 145-151.

Baghdadi N, Gratiot N, Lefebvre JP, Oliveros C, Bourguignon A (2004) Coastline and mud bank monitoring in French Guiana: contributions of radar and optical satellite imagery. Can J Remote Sens 30:109-122.

Benoit M., Marcos F., Becq F (1996). Development of a third generation shallow water wave model with unstructured spatial meshing. Proc. 25th Int. Conf. on Coastal Eng. (ICCE 1996, 2-6 September 1996, Orlando, Florida, USA), pp 465-478.

Booij N, Ris RC, Holthuijsen LH (1999) A third-generation wave model for coastal regions, Part I, Model description and validation, J Geoph Research 104(C4):7649-7666

Bourret A, Devenon J-L, Chevalier C (2005) Investigation on passive open boundary conditions adapted to the conjunction of strong currents, standing tidal wave and high stratification: Application to the French Guiana Continental Shelf. Continental Shelf Research 25(11):1353-1373.

Bourret A, Devenon J-L, Chevalier C (2008) Tidal influence on the hydrodynamics of the French Guiana continental shelf. Continental Shelf Research 28(7):951-961.

Callede J, Ronchail J, Guyot JL, De Oliveira E (2008). Amazonian deforestation: its influence on the Amazon discharge at Óbidos (Brazil). Revue des Sciences de l'Eau 21(1):59-72.

Chevalier C, Baklouti L., Ramanonjiarisoa A (2004) Modelling the influence of awind and rivers on current, salinity and temperature over the French Guiana continental shelf during the rainy season. J. Coastal Research 20(4):1183-1197.

Chevalier C, Froidefond JM, Devenon JL (2008) Numerical analysis of the combined action of littoral current, tide and waves on the suspended mud transport and on turbid plumes around French Guiana mud banks. Continental Shelf Research 28:545-560. 
CEREMA (2011). VAG: code de propagation de la houle (in French). http://www.eau-mer-fleuves.cerema.fr/vag-code-de-propagation-de-la-houle-a106.html (accessed April 2017).

Daniel JRK (1989). The chenier plain coastal system of Guyana. Marine Geology 90:283-287.

Danielsen F, Sørensen MK, Olwig MF, Selvam V, Parish F, Burgess ND, Hiraishi T, Karunagaran VM, Rasmussen MS, Hansen LB, Quarto A, Suryadiputra N (2005) The Asian tsunami: a protective role for coastal vegetation. Science 310:643. DOI:10.1126/science.1118387

De Graaff RF, Bijlsma AC (2005a) Institutional Capacity Building Activities on Guyana Sea Defences: Modelling Report, Volume 2: Flow Modelling. WL Delft Hydraulics.

De Graaff RF, Winterwerp JC, Luijendijk AP (2005b) Institutional Capacity Building Activities on Guyana Sea Defences: Modelling Report, Volume 3: Wave Modelling. WL Delft Hydraulics.

Delft Hydraulics Laboratory (1962) Demerara Coastal Investigation. Report on siltation of Demerara bar channel and coastal erosion in British Guiana, Delft.

Dewaelheyns Ph, Etneo L (2007) Modellering van de stromingen voor de kust van Suriname. MSc thesis, Dept. of Civil Engineering, KU Leuven (in Dutch).

Dirkx B, Fockedey B (2008) Modellering van de stromingen voor de kust van Suriname. MSc thesis, Dept. of Civil Engineering, KU Leuven (in Dutch).

Duke NC (2001) Gap creation and regenerative processes driving diversity and structure of mangrove ecosystems. Wetl Ecol Manag 9:257-269.

Ellison AM (2000) Mangrove restoration: do we know enough? Restoration Ecology 8(3):219229.

Erftemeijer P, Teunissen P (2009) ICZM Plan Suriname - Mangrove Report. Analysis of problems and solutions for the management of mangrove forests along Suriname's wild coast. Final Report, Paramaribo.

Escobar Ramos JS (2017) Hydrodynamic and cohesive sediments 2D modelling in Buenaventura Bay, Colombia. MSc thesis, IUPWARE program, KU Leuven.

Feagin RA, Mukherjee N, Shanker K, Baird AH, Cinner J, Kerr AM, Koedam N, Sridhar A, Arthur R, Jayatissa LP, Lo Seen D, Menon M, Rodriguez S, Shamsuddoha Md, DahdouhGuebas F (2010) Shelter from the storm? Use and misuse of coastal vegetation bioshields for managing natural disasters. Conservation Letters 3:1-11.

Field CD. (1999) Rehabilitation of mangrove ecosystems: an overview. Marine Pollution Bulletin 37(8-12):383-392.

Filizola N, Guyot, JL (2009). Suspended sediment yields in the Amazon basin: an assessment using the Brazilian national data set. Hydrological Processes 23:3207-3215.

Fiot J, Gratiot N (2006) Structural effects of tidal exposures on mudflats along the French Guiana coast. Marine Geology 228(1-4):25-37.

Froidefond JM, Pujos M, Andre X (1988) Migration of mud banks and changing coastline in French Guiana. Marine Geology 84:19-30.

Froidefond J, Gardel L, Guiral D, Parra M, Ternon J-F (2002) Spectral remote sensing reflectances of coastal waters in French Guiana under the Amazon influence. Remote Sensing of Environment 80(2):225-235.

Froidefond J, Lahet F, Hu C, Doxaran D, Guiral D, Prost M, Ternon J-F (2004 Mudflats and mud suspension observed from satellite data in French Guiana. Marine Geology 208(24):153-168. 
Fromard F, Puig H, Mougin E, Marty G, Betoull JL, Cadamuro L (1998) Structure, aboveground biomass and dynamics of mangrove ecosystems: new data from French Guiana. Oecologia 115:39-53

Fromard F, Vega C, Proisy C (2004) Half a century of dynamic coastal change affecting mangrove shorelines of French Guiana. A case study based on remote sensing data analyses and field surveys. Marine Geology 208:265-280.

Gardel A, Gratiot N (2005 A satellite image-based method for estimating rates of mud bank migration, French Guiana, South America. J Coast Res 21:720-728.

Gardel A, Gratiot N (2006) Monitoring of coastal dynamics in French Guiana from 16 years of SPOT images. J Coastal Research 39(SI):1502-1505.

Gardel A, Gensac E, Anthony EJ, Lesourd S, Loisel H (2011) Wave-formed mud bars: their morphodynamics and role in opportunistic mangrove colonization. J Coastal Research 64(SI):384-387.

Gardel A, Proisy C, Lesourd S, Philippe S, Caillaud J, Gontharet S, Anthony EJ, Brutier L (2009) A better understanding of mud cracking processes gained from in situ measurements on an intertidal mudflat in French Guiana. J Coastal Research 56(SI):424-428.

Gensac E, Gardel A, Lesourd S, Anthony EJ, Proisy C, Loisel H (2011). Short-term prediction of the evolution of mangrove surface areas: The example of the mud banks of Kourou and Sinnamary, French Guiana. J Coastal Research 64(SI):388-392.

Gensac E, Gardel A, Lesourd S, Brutier L (2015) Morphodynamic evolution of an intertidal mudflat under the influence of Amazon supply - Kourou mud bank, French Guiana, South America. Estuarine, Coastal and Shelf Science 158:53-62.

Gensac E, Martinez JM, Vantrepotte V, Anthony EJ (2016) Seasonal and inter-annual dynamics of suspended sediment at the mouth of the Amazon River: The role of continental and oceanic forcing, and implications for coastal geomorphology and mud bank formation. Continental Shelf Research 118:49-62.

Gratiot N (2011) Coastal erosion along the coast of Guiana Final Report, EuropeAid/ 124705/D/SER/GY Project: Technical Assistance for Capacity Building and Institutional Strengthening of the Sea Defences, Guyana. Works Services Group, Georgetown.

Gratiot N, Anthony EJ (2016) The role of flocculation and settling processes in geological development of the mangrove-colonized, Amazon-influenced mud bank coast of South America. Marine Geology 373:1-10.91.

Gratiot N, Anthony EJ, Gardel A, Gaucherel C, Proisy C, Wells JT (2008) Significant contribution of the 18.6 year tidal cycle to regional coastal changes. Nature Geoscience 1:169-172.

Gratiot N, Gardel A, Anthony EJ (2007) Trade-wind waves and mud dynamics on the French Guiana coast, South America: input from ERA-40 wave data and field investigations. Marine Geology 236:15-26.

Guyana Government Information Agency (2016). EU presents Coastal Engineering Design Manual to MPI.

http://gina.gov.gy/eu-presents-coastal-engineering-design-manual-to-mpi/ (retrieved May 2017)

Guyana Ministry of Finance (1996). Water management and flood control policies. National Development Strategy, Chapter 40. http://www.guyana.org/NDS/chap40.htm (retrieved May 2017)

Gyssels T, Van der Zype N (2006) Hydrodynamisch model voor Suriname: voorlopige versie. MSc thesis, Dept. of Civil Engineering, KU Leuven (in Dutch). 
Hawkes DD (1962) Erosion of tidal flats near Georgetown, British Guiana. Nature 196:128130.

Hermans P, Kroeders M (2012) Modellering van sedimenttransport langs de kust van Suriname. MSc thesis, Dept. of Civil Engineering, KU Leuven (in Dutch).

Hervouet JM (2007) Hydrodynamics of Free Surface Flows: Modelling with the finite element method. John Wiley and Sons, London.

Kranenburg WM, Winterwerp JC, de Boer GJ, Cornelisse JM, Zijlema M (2011) SWAN-mud: engineering model for mud-induced wave damping. J Hydraul Eng 137:959-975.

Lakhan VC, Pepper DA (1997) Relationship between concavity and convexity of a coast and erosion accretion patterns. J Coastal Research 13(1):226-232.

Lakhan VC, Cabana K, LaValle PD (2002). Heavy metal concentrations in surficial sediments from accreting and eroding areas along the coast of Guyana. Environmental Ecology 42:7380 .

Lakhan VC, Ahmad SR, Pariznganeh (2006). A Investigating shifting mud banks along a coast subject to cycles of accretion and erosion. Proc. Littoral Conf 2006 pp 90-97.

Landell Mills Limited (2013) Technical Assistance for Mangrove Rehabilitation: Final Report. Government of Guyana, Georgetown.

Lefebvre JP, Dolique F, Gratiot N (2004) Geomorphic evolution of a coastal mudflat under oceanic influences: an example from the dynamic shoreline of French Guiana. Marine Geology 208:191-205.

Les BAJ, Westra MR (2004) Institutional Capacity Building Activities on Guyana Sea Defences: Bathymetric Surevy Report. Royal Haskoning, Nijmegen.

Lewis III RR (2004) Ecological engineering for successful management and restoration of mangrove forests. Ecological Engineering 24(4):403-418.

Lewis III RR (2009) Methods and criteria for successful mangrove forest restoration. Chapter 28. In: Perillo GME, Wolanski E, Cahoon DR, Brinson MM (Eds), Coastal Wetlands: An Integrated Ecosystem Approach, Elsevier, pp 787-800.

Lovelock CE, Cahoon DR, Friess DA, Guntenspergen GR, Krauss KW, Reef R, Rogers K, Saunders ML, Sidik F, Swales A, Saintilan N, Thuyen LX, Triet T (2015) The vulnerability of Indo-Pacific mangrove forests to sea-level rise. Nature doi: 10.1038/nature15538

Machin J (2012) Technical Note: Trial of planitng coastal grasses to stablise mud banks and facilitate natural recuritment of mangroves in Guyana. Guyana Mangrove Restoration Project, Mon Repos.

Machin J, Lewis III RR (2013) Mangrove Forest Management and Restoration in Guyana. Guyana Mangrove Restoration Project, Mon Repos.

Martinez JM, Guyot JL, Filizola N, Sondag F (2009). Increase in suspended sediment discharge of the Amazon River assessed by monitoring network and satellite data. Catena 79:257-264.

Maza M, Lara JL, Losada IJ (2015) Tsunami wave interaction with mangrove forests: a 3-D numerical approach. Coastal Engineering 98:33-54.

Mazda Y, Magi M, Kogo M, Hong PN (1997) Mangroves as a coastal protection from waves in the Tong King delta, Vietnam. Mangroves and Salt Marshes 1:127-135.

McIvor AL, Möller I, Spencer T, Spalding M (2012) Reduction of wind and swell waves by mangroves. Natural Coastal Protection Series: Report 1. Cambridge Coastal Research Unit Working Paper 40. The Nature Conservancy and Wetlands International.

McIvor AL, Spencer T, Möller I, Spalding M (2013) The response of mangrove soil surface elevation to sea level rise. Natural Coastal Protection Series: Report 3. Cambridge Coastal Research Unit Working Paper 42. The Nature Conservancy and Wetlands International. 
Mehta AJ (2014) An Introduction to Hydraulics of Fine Sediment Transport. Advanced Series on Ocean Engineering, Vol 38. World Scientific Publishing Co., Singapore.

Mehta AJ, Lee SC, Li Y (1994) Fluid mud and water waves: a brief review of interactive processes and simple modeling approaches. Dreding Research Program Report DRP-94-4, US Army Corps of Engineers, Vicksburg (MS).

Morelock J (1972) Guyana-Orinico continental shelf sediments. Bol Inst Oceanogr Univ Oriente 11(1):57-61.

NAREI (2014) Mangrove Department Annual Report 2013. National Agricultural Research and Extension Institute, Mon Repos.

Nedeco (1968) Surinam Transportation Study: Report on Hydraulic Investigation. Netherlands Engineering Consultants, The Hague, 293p.

Nedeco (1972). Report on Sea Defence Studies. Netherlands Engineering Consultants, The Hague.

Nota DJG (1958) Sedimentation auf dem West-Guyana Schelf. Geologische Rundschau 47(1):167-177 (in German).

Odle MA, Arjoon PR (1971) A benefit/cost analysis of sea defence expenditure in Guyana. Social and Economic Studies 20(1):83-98.

Orseaux S (2016) Dynamique sédimentaire d'un fleuve tropical sous influence amazonienne: le cas du Mahury, Guyane Française. PhD dissertation, Université du Littoral Côte D’Opale (in French).

Pelckmans A (2014) Modellering van golven en sedimenttransport langs de kust van Suriname. MSc thesis, Dept. of Civil Engineering, KU Leuven (in Dutch).

Pelling M (1997). The political ecology of flood hazard in urban Guyana. Geoforum 30:249261.

Proisy C, Gratiot N, Anthony EJ, Gardel A, Fromard F, Heuret P (2009) Mud bank colonization by opportunistic mangroves: a case study from French Guiana using lidar data. Continental Shelf Research 29:632-641.

Proisy C, Degenne P, Anthony EJ, Berger U, Blanchard E, Fromard F, Gardel A, Olagoke A, Santos VF, Walcker R, Lo Seen D (2016) A multiscale simulation approach for linking mangrove dynamics to coastal processes using remote sensing observations. In: VilaConcejo A, Bruce E, Kennedy DM, McCarroll RJ (eds), Proc 14th Int Coastal Symp (Sydney, Australia). J Coastal Research, SI75:810-814.

Pultoo TRD (2015) Onderzoek naar de stabiliteit, toepasbaarheid en duurzaamheid van de "sediment trapping unit" te Weg naar Zee. BSc thesis. Faculty of Technological Sciences, Anton de Kom Universiteit van Suriname (in Dutch).

Rine JM (1980) Depositional environments and holocene reconstruction of an argillaceous mud belt - Suriname, South America. PhD dissertation, University of Miami, Coral Gables (FL).

Rine JM, Ginsburg RN (1985) Depositional facies of a mud shoreface in Suriname, South America. A mud analoque to sandy shallow-marine deposits. J Sediment Petrol 55:633-652.

Robertson R (2014) Importance of Avicennia Germinans (Black mangroves) at Chateau Margot, East Coast Demerara, Georgetown, Guyana. MSc Thesis, University of West Indies.

Sakakiyama T, Bijker EW (1989) Mass transport velocity in mud layer due to progressive waves. J Waterway, Port, Coastal and Ocean Eng 115(5): 614-633.

Tol S (2016) Construction of permeable dam structures as sediment traps and basis for mangrove rehabilitation. Wetlands International. 
(http://panorama.solutions/en/building-block/construction-permeable-dam-structuressediment-traps-and-basis-mangrove, retrieved May 2017).

Tonneijck F (2013) Building with Nature Indonesia. Opportunities for CC adaptation and Mitigation. Wetlands International/ Mangrove Capital. UNFCCC Bonn 2013.

Toorman EA (1996) Sedimentation and self-weight consolidation: general unifying theory. Géotechnique 46(1):103-113

Toorman EA (1997) Modelling the thixotropic behaviour of dense cohesive sediment suspensions. Rheologica Acta 36(1):56-65.

Toorman EA (2008) An investigation into the thixotropic wave dissipation potential of fluid mud. AGU Chapman Conference on Physics of Wave-Mud Interaction (Amelia Island, Florida, November 2008). Book of Abstracts, p 24.

Topper E (2012). Assessment of the sustainable coastal zone protection through mangrove management project. Ministry of Public Works and Communications, Works Services Group, Georgetown.

Vantrepotte V, Gensac E, Loisel H, Gardel A, Dessailly D, Mériaux X (2013) Satellite assessment of the coupling between in water suspended particulate matter and mud banks dynamics over the French Guiana coastal domain. J South American Earth Sciences 44:2534.

Villarroel A (2009) Stroming van vloeibaar slib. MSc thesis, Dept. of Civil Engineering, KU Leuven (in Dutch)

Walcker R, Anthony EJ, Cassou C, Aller RC, Gardel A, Proisy C, Martinez JM, Fromard F (2015) Fluctuations in the extent of mangroves driven by multi-decadal changes in north atlantic waves. J Biogeography 42:2209-2219.

Welage SJ (2005) Coastal evolution Guyana: modelling and a historical investigation. MSc. Thesis, Delft University of Technology.

Wells JT, Coleman JM, Wiseman WJ (1981) Suspension and transportation of fluid mud by solitary-like waves. Coastal Studies Institute, Louisiana State University, Baton Rouge, Louisiana.

Wells JT, Coleman JM (1981) Physical processes and fine-grained sediment dynamics, coast of Surinam, South America. J Sedimentary Petrology 31(4):1053-1068.

Westra MR (2004) Institutional Capacity Building Activities on Guyana Sea Defences: Morphological Survey and Oceanographic Monitoring Report. Royal Haskoning, Nijmegen.

Winterwerp JC, de Graaff RF, Luijendijk AP (2005b) Institutional Capacity Building Activities on Guyana Sea Defences: Modelling Report, Volume 4: Morphology Modelling. WL Delft Hydraulics.

Winterwerp JC, de Graaff RF, Groeneweg J, Luijendijk AP (2007) Modelling of wave damping at Guyana mud coast. Coastal Engineering 54(3):249-261.

Winterwerp JC, Erftemeijer PLA, Suryadiputra N, van Eijk P, Zhang L (2013) Defining ecomorphodynamic requirements for rehabilitating eroding mangrove-mud coasts. Wetlands 33(3):515-526.

Wong PP, Losada IJ, Gattuso J-P, Hinkel J, Khattabi A, McInnes KL, Saito Y, Sallenger A (2014) Coastal systems and low-lying areas. In: Climate Change 2014: Impacts, Adaptation, and Vulnerability. Part A: Global and Sectoral Aspects. Contribution of Working Group II to the Fifth Assessment Report of the Intergovernmental Panel on Climate Change [Field CB, Barros VR, Dokken DJ, Mach KJ, Mastrandrea MD, Bilir TE, Chatterjee M, Ebi KL, 
Estrada YO, Genova RC, Girma B, Kissel ES, Levy AS, MacCracken S, Mastrandrea PR, White LL (eds.)]. Cambridge University Press, Cambridge, pp 361-409.

Wong T, Kroonenberg S, Augustinus P (2017). Geologie en landschap van Suriname. Stichting LM Publishers, Volendam, the Netherlands, 198p (in Dutch).

Wongsoredjo S (2017) Numerical modelling of sediment transport along a mud dominated coast. MSc in Earth Sciences Internship Report, Utrecht University (the Netherlands) and KU Leuven (Belgium).

Zhang K, Liu H, Li Y, Xu H, Shen J, Rhome J, Smith III TJ (2012) The role of mangroves in attenuating storm surges. Estuarine, Coastal and Shelf Sciences 102-103:11-23. 